\begin{tabular}{|l|l|}
\hline 2. To: (Receiving organization) & 3. From: (originating Organization) \\
Packaging Engineering & Packaging Engineering \\
\hline 5. Proj./Prog./Dept./Div.: & 6. Design Authority/ Design Agent/Cog \\
03 E00 & E. C. MCCoy \\
\hline
\end{tabular}

8. Originator Remarks:

For approval.

11. Receiver Remarks:
11A. Design Basel ine Document?

[] Yes
[X] No
4. Related EDT No.:

NA

7. Purchase order No.:

NA

9. Equip./Component No.:

NA

10. System/Bldg./Facility:

NA

12. Major Assm. Dwg. Mo.:

NA

13. Permit/Permit Application No.: NA

14. Required Response Date:

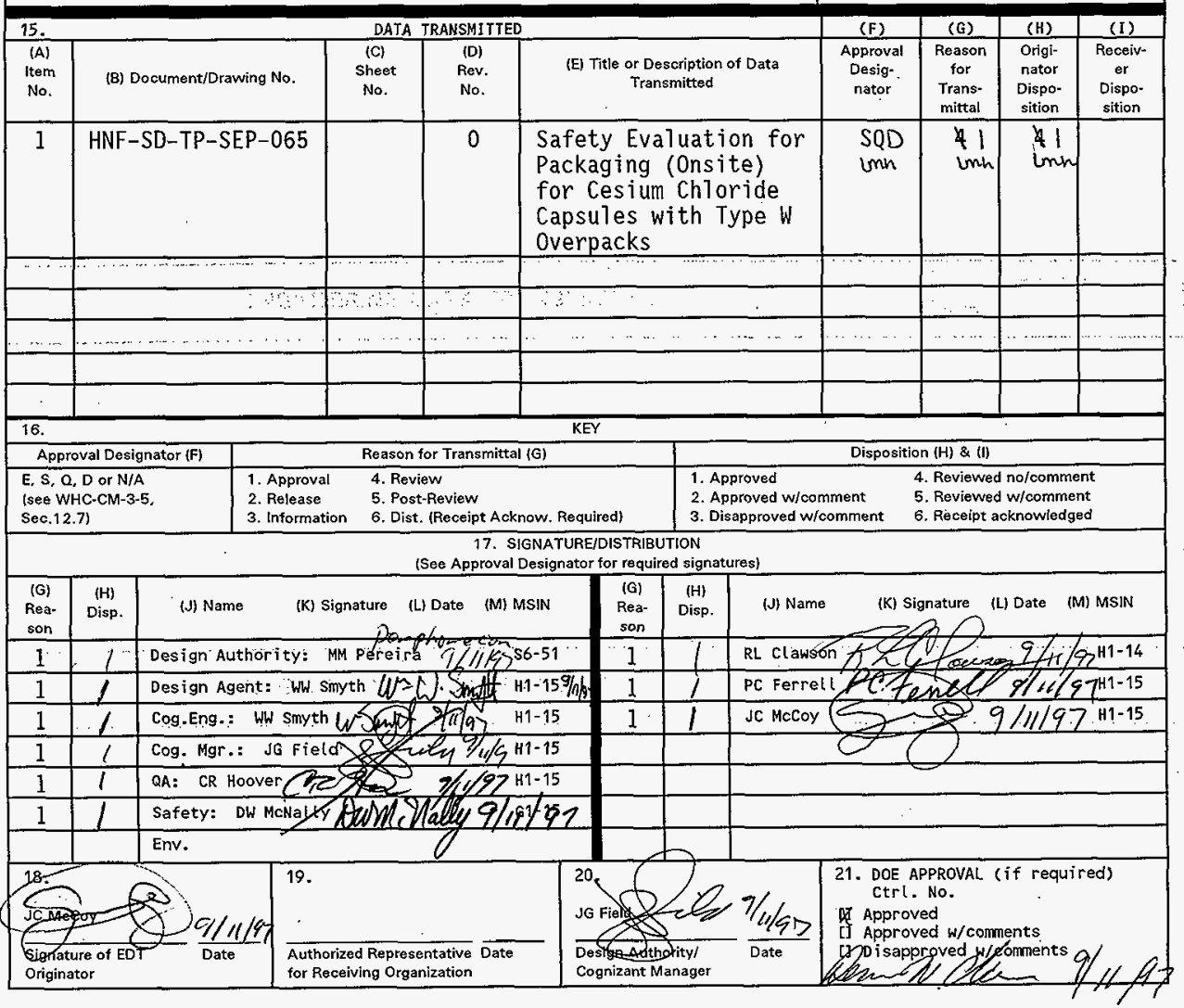

BD-7400-172-2 (05/96) GEF097 


\section{Safety Evaluation for Packaging (Onsite) for Cesium Chloride Capsules with Type W Overpacks}

J. C. McCoy

Waste Management Federal Services, Inc., Northwest Operations, Richland, WA 99352

U.S. Department of Energy Contract DE-AC06-96RL13200

EDT/ECN: EDT 621893 UC: 513

Org Code: 03E00

B\&R Code: EW7002010

Charge Code: KW64B

Total Pages: -130 - $132 / 30$

Key Words: BUSS Cask, Type W Overpack, onetime onsite shipment

Abstract: This Safety Evaluation for Packaging (SEP) documents the evaluation of a new basket design and overpacked cesium chloride capsule payload for the Beneficial Uses Shipping System (BUSS) Cask in accordance with the onsite transportation requirements of the Hazardous Material Packaging and Shipping manual, WHC-CM-2-14. This design supports the onetime onsite shipment of 16 cesium chloride capsules with Type $W$ overpacks from the 324 Building to the 224T Building at the Waste Encapsulation and Storage Facility (WESF). The SEP is valid for a onetime onsite shipment or until August 1, 1998, whichever occurs first.

TRADEMARK DISCLAIMER. Reference herein to any specific comercial product, process, or service by trade name, tradenark, manufacturer, or otherwise, does not necessarily constitute or inply its endorsement, recommendation, or favoring by the United States Government or any agency thereof or its contractors or subcontractors.

Printed in the United States of America. To obtain copies of this document, contact: Document Control Services, P.O. Box 950, Mailstop H6-08, Richland WA 99352, Phone (509) 372-2420; Fax (509) 376-4989.
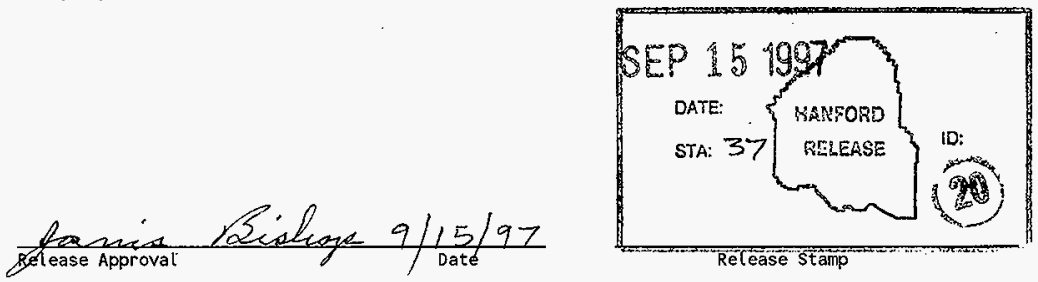


\section{CONTENTS}

\section{PART A: PACKAGE DESCRIPTION AND OPERATIONS}

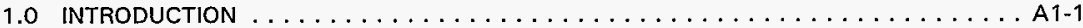

1.1 REVIEW AND UPDATE CVCLES $\ldots \ldots \ldots \ldots \ldots \ldots \ldots \ldots \ldots \ldots \ldots \ldots \ldots \ldots \ldots$

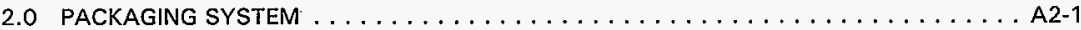

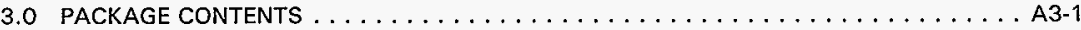

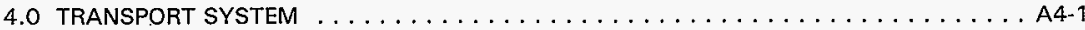

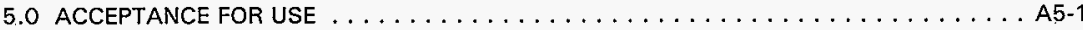

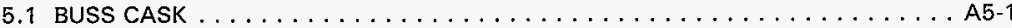

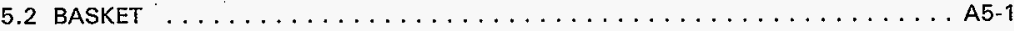

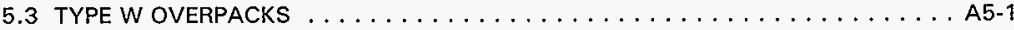

6.0 OPERATING REQUIREMENTS $\ldots \ldots \ldots \ldots \ldots \ldots \ldots \ldots \ldots \ldots \ldots \ldots \ldots \ldots \ldots$

7.0 QUALITY ASSURANCE $\ldots \ldots \ldots \ldots \ldots \ldots \ldots \ldots \ldots \ldots \ldots \ldots \ldots \ldots \ldots$

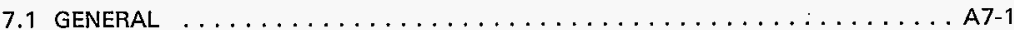

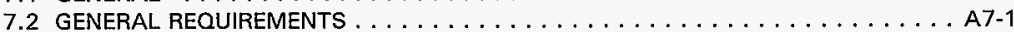

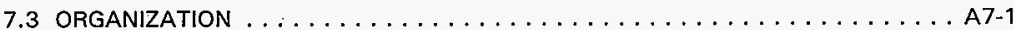

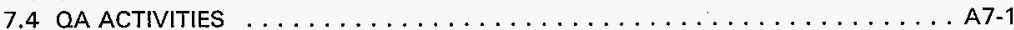

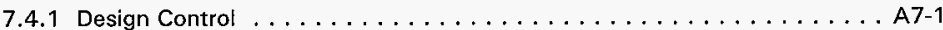

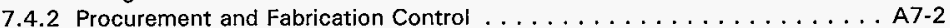

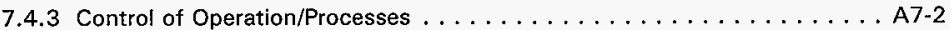

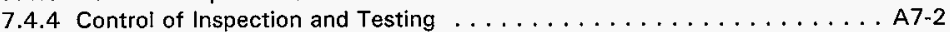

7.4 .5 Control of Operations and Maintenance $\ldots \ldots \ldots \ldots \ldots \ldots \ldots$. . . . . .

7.4 .6 Test Control . . . . . . . . . . . . . . . . . . . . A7-2

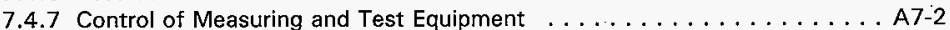

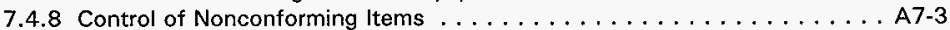

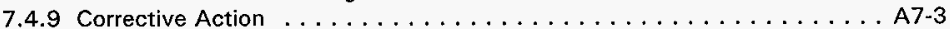

7.4.10 QA Records and Document Control . . . . . . . . . . . . A7-3

7.4 .11 Independent Assessments $\ldots \ldots \ldots \ldots \ldots \ldots \ldots \ldots \ldots \ldots \ldots \ldots$

8.0 MAINTENANCE $\ldots \ldots \ldots \ldots \ldots \ldots \ldots \ldots \ldots \ldots \ldots \ldots \ldots$. $\ldots \ldots \ldots \ldots$

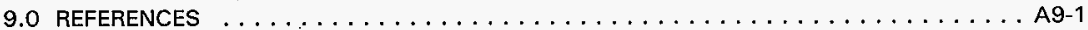

10.0 APPENDIX: DRAWINGS $\ldots \ldots \ldots \ldots \ldots \ldots \ldots \ldots \ldots \ldots \ldots \ldots \ldots \ldots \ldots \ldots$

PART B: PACKAGE EVALUATION

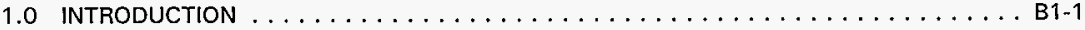

1.1 EVALUATION SUMMARY AND CONCLUSIONS $\ldots \ldots \ldots \ldots \ldots \ldots \ldots \ldots \ldots$ B1-1

1.1 .1 Contents . . . . . . . . . . . . . . . . . . . . B1-1

1.1 .2 Radiological Risk . . . . . . . . . . . . . . . . . . . . . .

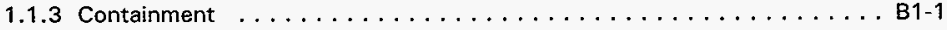




\section{CONTENTS (cont)}

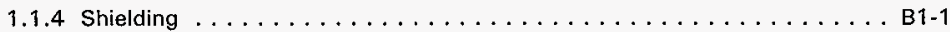

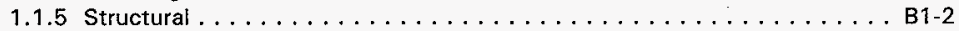

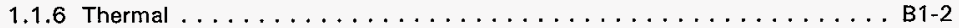

1.1 .7 Gas Generation . . . . . . . . . . . . . . . . . B1-2

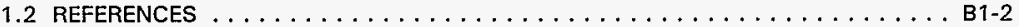

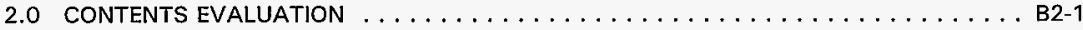

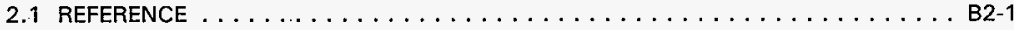

3.0 RADIOLOGICAL RISK EVALUATION $\ldots \ldots \ldots \ldots \ldots \ldots \ldots \ldots \ldots \ldots \ldots \ldots$

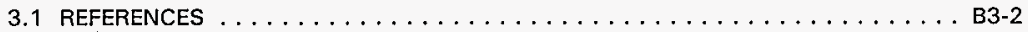

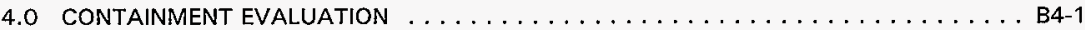

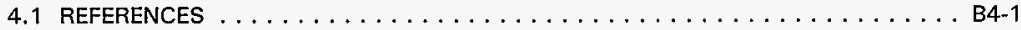

5.0 SHIELDING EVALUATION $\ldots \ldots \ldots \ldots \ldots \ldots \ldots \ldots \ldots \ldots \ldots \ldots \ldots \ldots$ B5-1

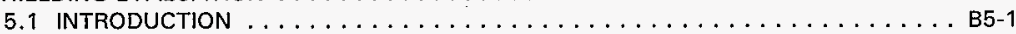

5.2 DIRECT RADIATION SOURCE SPECIFICATION $\ldots \ldots \ldots \ldots \ldots \ldots \ldots$. . . . .

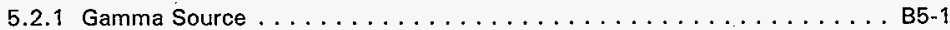

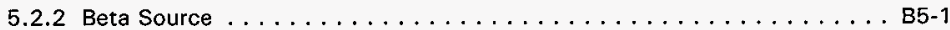

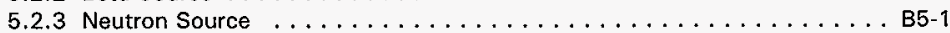

5.3 SUMMARY OF SHIELDING PROPERTIES OF MATERIALS $\ldots \ldots \ldots \ldots \ldots \ldots$ B $\ldots \ldots-1$

5.4 NORMAL CONDITIONS OF TRANSPORT $\ldots \ldots \ldots \ldots \ldots \ldots \ldots \ldots \ldots$. $\ldots \ldots$

5.4 .1 Conditions to be Evaluated . . . . . . . . . . . . . . . . B5-2

5.4 .2 Acceptance Criteria . . . . . . . . . . . . . . . . . . B5-2

5.4 .3 Shielding Model $\ldots \ldots \ldots \ldots \ldots \ldots \ldots \ldots \ldots \ldots \ldots$. . . . . . . . . .

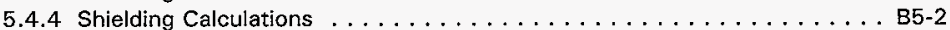

5.5 ACCIDENT CONDITIONS $\ldots \ldots \ldots \ldots \ldots \ldots \ldots \ldots \ldots \ldots \ldots \ldots$. . . . . . $\ldots \ldots$

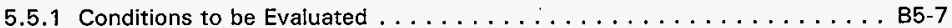

5.5 .2 Acceptance Criteria . . . . . . . . . . . . . . . . . . B5-7

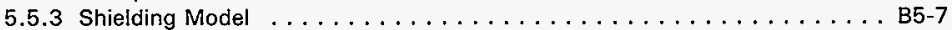

5.6 SHIELDING EVALUATION AND CONCLUSIONS $\ldots \ldots \ldots \ldots \ldots \ldots \ldots \ldots \ldots . . . . .7$

5.7 EVALUATION OF THE THERMAL DEPOSITION FRACTIONS FOR THE CASK . . . B B5-7

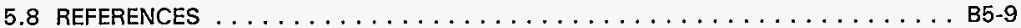

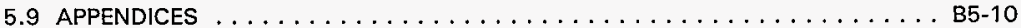

5.9 .1 MCNP Input File for Shielding Model . . . . . . . . . . . . . B5-10

5.9 .2 MCNP Input File for Energy Deposition Model . . . . . . . . . . . . B5-18

5.9 .3 Checklist for Peer Review . . . . . . . . . . . . . . . . . B5-24

6.0 CRITICALITY EVALUATION $\ldots \ldots \ldots \ldots \ldots \ldots \ldots \ldots \ldots \ldots \ldots \ldots \ldots \ldots$

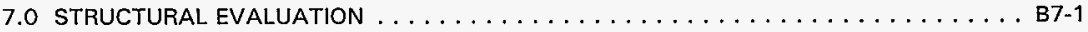

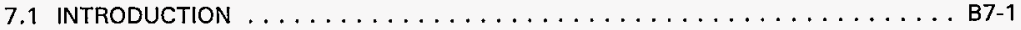

7.2 WEIGHT OF BASKET AND CONTENTS $\ldots \ldots \ldots \ldots \ldots \ldots \ldots \ldots \ldots \ldots \ldots$ B 1

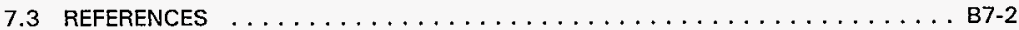

8.0 THERMAL EVALUATION $\ldots \ldots \ldots \ldots \ldots \ldots \ldots \ldots \ldots \ldots \ldots \ldots$. . . . . . . . . . .

8.1 INTRODUCTION $\ldots \ldots \ldots \ldots \ldots \ldots \ldots \ldots \ldots \ldots \ldots \ldots \ldots \ldots \ldots$ B8-1

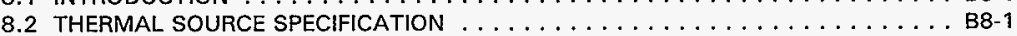

8.3 THERMAL PROPERTIES OF MATERIALS $\ldots \ldots \ldots \ldots \ldots \ldots \ldots \ldots \ldots \ldots$. $\ldots \ldots$.

8.3.1 T304 Stainless Steel Properties . . . . . . . . . . . . . . . . B8-2 


\section{CONTENTS (cont)}

8.3.2 Helium Properties $\ldots \ldots \ldots \ldots \ldots \ldots \ldots \ldots \ldots \ldots \ldots \ldots$. . . . . . . . . .

8.3.3 Properties of Cesium Chioride . . . . . . . . . . . . . . B8-3

8.3.4 Properties of Air and the Convection Rate at the Cask Surface . . . . . . B8-4

8.4 INITIAL CONDITIONS $\ldots \ldots \ldots \ldots \ldots \ldots \ldots \ldots \ldots \ldots \ldots \ldots$

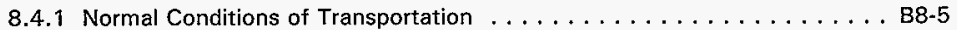

8.4.2 Hypothetical Accident Conditions . . . . . . . . . . . . . B8-5

8.5 THERMAL ANALYSES $\ldots \ldots \ldots \ldots \ldots \ldots \ldots \ldots \ldots \ldots \ldots \ldots \ldots$

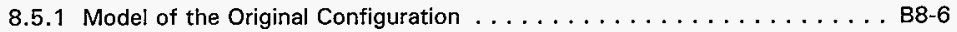

8.5.2 Modeling 16 Overpacked Capsules . . . . . . . . . . . . . B8-7

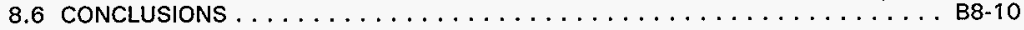

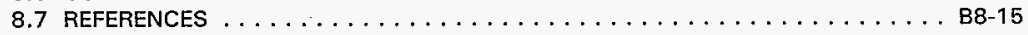

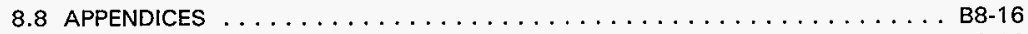

8.8.1 Convection and Radiation Calculations . . . . . . . . . . . B8-16

8.8.2 BUSS Cask Heat Transfer Calculations . . . . . . . . . . . . B8-19

8.8.3 Capsule Arrangement in Cask . . . . . . . . . . . . . . . . B8-28

8.8.4 Finite Element Analysis of SARP Configuration . . . . . . . . . . . B8-29

8.8.5 Finite Element Analysis of 16 Overpacked Capsules in an Open Basket . B8-37

8.8.6 Peer Review Checklist . . . . . . . . . . . . . . . . . B8-59

9.0 PRESSURE AND GAS gENERATION $\ldots \ldots \ldots \ldots \ldots \ldots \ldots \ldots \ldots \ldots \ldots \ldots \ldots$

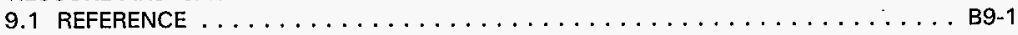

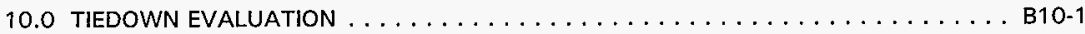

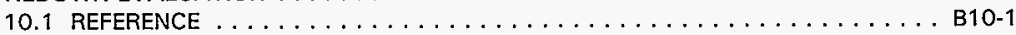


HNF-SD-TP-SEP-065 Rev. 0

\section{LIST OF FIGURES}

A6-1. Relative Position of Cesium Chloride Capsules in Basket . . . . . . . . . . A6-2

B5-1: Simplified Radial Sketch of BUSs Cask $\ldots \ldots \ldots \ldots \ldots \ldots \ldots \ldots \ldots \ldots$

B5-2. Simplified Axial Sketch of BUSs Cask $\ldots \ldots \ldots \ldots \ldots \ldots \ldots \ldots \ldots$

B8-1. Preliminary Models. . . . . . . . . . . . . . . . . . . . B8-8

B8-2. B16a Plots $\ldots \ldots \ldots \ldots \ldots \ldots \ldots \ldots \ldots \ldots \ldots \ldots \ldots \ldots \ldots \ldots \ldots$

\section{LIST OF TABLES}

A3-1. Capsule Activity and Thermal Data $\ldots \ldots \ldots \ldots \ldots \ldots \ldots \ldots \ldots \ldots \ldots \ldots$

B5-1. ANSI/ANS (1991) Photon Fluence to Dose Conversion Factors . . . . . . . . . . B5-3

B5-2. BUSS Cask Radial Geometry and Material Composition . . . . . . . . . . B5-3

B5-3. BUSS Axial Geometry and Material Composition . . . . . . . . . . . . B5-4

B5-4. Dose Rates for the BUss Cask . . . . . . . . . . . . . . . B5-6

B5-5. Dose Rates for the Buss Cask . . . . . . . . . . . . . . . . B5-7

B5-6. Summary of Energy Deposition in the BUSS Cask . . . . . . . . . . . . B5-9

B8-1. SARP Results and Allowable Temperatures $\ldots \ldots \ldots \ldots \ldots \ldots \ldots \ldots \ldots \ldots$. . . . . . .

B8-2. Stainless Steel Thermal Conductivity $\ldots \ldots \ldots \ldots \ldots \ldots \ldots \ldots \ldots \ldots \ldots$

B8-3. Helium Conductivity, $\mathrm{K} \ldots \ldots \ldots \ldots \ldots \ldots \ldots \ldots \ldots \ldots \ldots \ldots \ldots$

B8-4. Heat Distribution within the BUSs Cask $\ldots \ldots \ldots \ldots \ldots \ldots \ldots \ldots \ldots \ldots$

B8-5. Thermal Properties of Air $\ldots \ldots \ldots \ldots \ldots \ldots \ldots \ldots \ldots \ldots \ldots \ldots \ldots \ldots$

B8-6. Results of the SARP Model; Temp, ${ }^{\circ} \mathrm{F} \ldots \ldots \ldots \ldots \ldots \ldots \ldots \ldots \ldots$

B8-7. Temperature Results, ${ }^{\circ} \mathrm{F} \ldots \ldots \ldots \ldots \ldots \ldots \ldots \ldots \ldots \ldots$

B8-8. Maximum Temperatures in Base Case and Variations . . . . . . . . . . B8-9 
HNF-SD-TP-SEP-065 Rev. 0

\section{LIST OF TERMS}

$\begin{array}{ll}\text { ANSi } & \text { American National Standards Institute } \\ \text { BUSS } & \text { Beneficial Uses Shipping System } \\ \text { Ci } & \text { curie } \\ \text { COC } & \text { Certificate of Compliance } \\ \text { DOE } & \text { U.S. Department of Energy } \\ \text { ft } & \text { feet } \\ \text { HAC } & \text { hypothetical accident conditions } \\ \text { HRCQ } & \text { highway route controlled quantity } \\ \text { in. } & \text { inch } \\ \text { kg } & \text { kilogram } \\ \text { lb } & \text { pound } \\ \text { MCNP } & \text { Monte Carlo N-Particle } \\ \text { NCT } & \text { normal conditions of transport } \\ \text { QA } & \text { quality assurance } \\ \text { QC } & \text { quality control } \\ \text { SARP } & \text { Safety Analysis Report for Packaging } \\ \text { SEP } & \text { Safety Evaluation for Packaging } \\ \text { W } & \text { Watt } \\ \text { WESF } & \text { Waste Encapsulation and Storage Facility } \\ \text { WMNW } & \text { Waste Management Federal Services, Inc., Northwest Operations }\end{array}$ 
This page intentionaliy left blank. 


\section{SAFETY EVALUATION FOR PACKAGING (ONSITE) FOR CESIUM CHLORIDE CAPSULES WITH TYPE W OVERPACKS}

\section{PART A: PACKAGE DESCRIPTION AND OPERATIONS}

\subsection{INTRODUCTION}

This Safety Evaluation for Packaging (SEP) documents the evaluation of a new basket design and overpacked cesium chloride capsule payload for the Beneficial Uses Shipping System (BUSS) Cask in accordance with the onsite transportation requirements of WHC-CM-2-14, Hazardous Material Packaging and Shipping. This design will support the onetime onsite shipment of 16 cesium chloride capsules with Type W overpacks from building 324, in the Hanford 300 Area, to building 224T, the Waste Encapsulation and Storage Facility (WESF), in the Hanford 200 East Area.

\subsection{REVIEW AND UPDATE CYCLES}

This SEP is valid for a onetime shipment or until August 1, 1998, whichever occurs first. An update or upgrade to this document is required beyond that date. 
This page intentionally left blank. 


\subsection{PACKAGING SYSTEM}

This SEP supports the onetime onsite shipment of 16 cesium chloride capsules in Type $W$ overpacks. As the Type $W$ overpacked capsules will not fit into the original BUSS Cask basket, a new basket design will be used for this shipment.

The BUSS Cask is certified by the U.S. Department of Energy (DOE) to transport up to 16 doubly encapsulated, special form, cesium chloride capsules. The BUSS Cask Safety Analysis Report for Packaging (SARP) (SNL 1994) and Certificate of Compliance (CoC) (DOE 1996) allow shipment of up to $850,000 \mathrm{Ci}$ of ${ }^{137} \mathrm{Cs}$, with a thermal load of $4,000 \mathrm{~W}$. The BUSS payload weight (including basket) is limited to $907 \mathrm{~kg}(2,000 \mathrm{lb})$. The fully loaded cask will weigh no more than $15,310 \mathrm{~kg}(33,700 \mathrm{lb})$. Although overpacked capsules and new basket design meet the BUSS Cask SARP parameters, the SARP will not be amended for this payload.

The 16 capsules to be shipped, as described in Part A, Section 3.0, have compromised containment boundaries due to swelling or broken welds and as such do not meet special form criteria. Therefore, these capsules will be repackaged in Type $W$ overpacks. The Type $W$ overpack, as detailed in drawing $\mathrm{H}-3-307504$ (Part A, Section 10.0), will be tested to the requirements of 49 CFR 173 for special form class 7 (radioactive) material and American Nationa! Standards Institute (ANSI) N43.6, Sealed Radioactive Sources, Classification (ANSI 1989). The overpacked capsules will not be certified as special form materials; however, they do meet all other conditions required by the BUSS SARP, as shown in Part B of this SEP. With the TYpe W overpacks, each capsule will weigh no more than $13.31 \mathrm{~kg}(29.35 \mathrm{lb})$, for a total of $213 \mathrm{~kg}$ $(469.6 \mathrm{lb})$. The activity and thermal limits for the payload are described in Part A, Section 3.0, and are within the limits allowed for the BUSS Cask..

The new 16 capsule basket (drawing $\mathrm{H}-2-828979$ [Part A, Section 10.0]) will be used to transport the overpacked capsules in the BUSS Cask in place of the original basket. The new basket weighs approximately $90.7 \mathrm{~kg}(200 \mathrm{lb}$.)

The total weight of the payload and basket, estimated to be approximately $304 \mathrm{~kg}(670 \mathrm{lb})$, is well within the limits of the BUSS Cask SARP (SNL 1994). 
HNF-SD-TP-SEP-065 Rev. 0

This page intentionally left blank.

A2-2 


\subsection{PACKAGE CONTENTS}

Table A3-1 lists the capsules that will be transported:

Table A3-1. Capsule Activity and Thermal Data.

\begin{tabular}{|c|c|c|c|c|}
\hline \multicolumn{2}{|c|}{ Capsule Serial Number } & \multicolumn{2}{|c|}{ Activity $\left({ }^{137} \mathrm{Cs}\right)$} & \multirow{2}{*}{$\begin{array}{l}\text { Estimated Power } \\
\text { (W) }\end{array}$} \\
\hline Outer Capsule & Inner Capsule & $\mathrm{TBq}$ & $\mathrm{Ci}$ & \\
\hline C-105 & C-283 & 1,843 & 49,816 & 234.14 \\
\hline C-1093 & C- 1245 & 1,652 & 44,639 & 209.8 \\
\hline C-287 & $\mathrm{C}-237$ & 1,539 & 41,590 & 199.58 \\
\hline $\mathrm{C}-913$ & $C-1035$ & 1,554 & 42,010 & 197.45 \\
\hline$C-1600$ & $C-1631$ & 1,517 & 40,998 & 192.69 \\
\hline$C-1368$ & C-1544 & 1,530 & 41,362 & 194.4 \\
\hline C-1562 & $C-1585$ & 1,514 & 40,922 & 192.33 \\
\hline C-849 & $\mathrm{C}-784$ & 1,478 & 39,939 & 187.71 \\
\hline $\mathrm{C}-930$ & C-914 & 1,477 & 39,929 & 187.67 \\
\hline C-1504 & C- 1560 & 1,443 & 38,993 & 183.27 \\
\hline C-1592 & $C-1636$ & 1,411 & 38,130 & 183.01 \\
\hline C-1507 & $C-1622$ & 1,430 & 38,653 & 181.67 \\
\hline C-1553 & $\mathrm{C}-1581$ & 1,413 & 38,179 & 179.44 \\
\hline $\mathrm{C}-1196$ & C-1263 & 1,387 & 37,498 & 176.24 \\
\hline $\mathrm{C}-811$ & $\mathrm{C}-992$ & 1,380 & 37,297 & 175.3 \\
\hline$C-1503$ & $C-1596$ & 1,301 & 35,150 & 173.64 \\
\hline Total & & 23,869 & 645,105 & 3,048 \\
\hline Average & & 1,492 & 40,319 & 190.52 \\
\hline $\begin{array}{l}\text { Standard } \\
\text { deviation }\end{array}$ & & & & 14.70 \\
\hline Maximum & & 1,843 & 49,816 & 234.14 \\
\hline $\begin{array}{l}\text { SARP limit, per } \\
\text { capsule }\end{array}$ & & 2,590 & 70,000 & 250 \\
\hline
\end{tabular}

'Activity limit of 2,590 Tbq $(70,000 \mathrm{Ci})$ is based on shielding.

${ }^{2}$ Estimated activity is given as $\mathrm{Tbq}(\mathrm{Ci})$ of ${ }^{137} \mathrm{Cs}$.

${ }^{3}$ This shipment is highway route controlled quantity (HRCO), 49 CFR 173 .

${ }^{4}$ Capsule data is from the WESF Encapsulation Data Base System

49 CFR 173, 1997, "Shippers--General Requirements for Shipments and Packagings," Code of Federal Regulations, as amended. 
This page intentionally left blank. 


\section{HNF-SD-TP-SEP-065 Rev, O}

\subsection{TRANSPORT SYSTEM}

The BUSS Cask, handling fixtures, and its dedicated transport trailer shall be used. These are detailed in the BUSS Cask SARP (SNL 1994). All SARP procedures, radiation, and contamination limits shall be adhered to. As this shipment does not comply with all SARP and CoC requirements for offsite shipment, the public access roads shall be barricaded during transportation. 
HNF-SD-TP-SEP-065 Rev. 0

This page intentionally left blank. 
HNF-SD-TP-SEP-065 ReV. 0

\subsection{ACCEPTANCE FOR USE}

\subsection{BUSS CASK}

Prior to use, all maintenance requirements shall be documented in accordance with the requirements of the SARP (SNL 1994) as shown in Part A, Section 6.0.

\subsection{BASKET}

The basket will be inspected as part of the fabrication process to ensure conformance with drawing H-2-828979 (Part.A, Section 7.0). Prior to each use, the basket will inspected in accordance with WESF procedures.

\subsection{TYPE W OVERPACKS}

Prior to transportation of the Type W overpacked capsules to WESF, the overpack design shall have passed the special form testing requirements of 49 CFR 173 and ANSI N43.6.

The Type $W$ overpacks shall be inspected as part of the fabrication process for conformance with drawing $\mathrm{H}-3-307504$ (Part A, Section 10.0). After installation, the overpacks shall be inspected in accordance with WESF procedures. 
HNF-SD-TP-SEP-065 ReV. 0

This page intentionally left blank.

A5-2 


\subsection{OPERATING REQUIREMENTS}

The using facilities (WESF and building 324) will write detailed operating procedures in order to use the BUSS Cask and the transport system. The requirements listed below shall be incorporated into the operating procedures in order to maintain compliance with this SEP.

1. New seals will be installed on the BUSS Cask prior to shipment (SNL. 1994).

2. The BUSS Cask shall satisfy the requirements of Chapter 7, "Operating Procedures," and Chapter 8, "Acceptance Tests and Maintenance Program," of the SARP (SNL 1994).

3. Prior to shipment, the Type $W$ overpacked capsules shall have been demonstrated to meet the requirements for special form materials (49 CFR 173, ANSI N43.6). The capsules will not be certified as special form material.

4. The shipper shall ensure that the transit and wait period between loading and unloading the BUSS Cask will not exceed 30 days.

5. Overpacked capsules shall be marked externally so they are identifiable. Records shall be maintained cross referencing the Type $W$ overpack serial number to the capsule it contains.

6. Prior to shipment, the 16 capsules will be cleaned and tested for external contamination to confirm that no capsule is leaking.

7. The overpacked capsules shail be placed in the basket in the relative positions shown in Figure A6-1. This arrangement ensures that the temperature of any capsule remains below $462{ }^{\circ} \mathrm{C}\left(864{ }^{\circ} \mathrm{F}\right)$.

Note that the power, position number, and outer capsule serial number are shown in Figure A6-1 for each capsule. Refer to Table A3-1 to cross-reference inner and outer capsule serial numbers. 
Figure A6-1. Relative Position of Cesium Chloride Capsules in Basket.

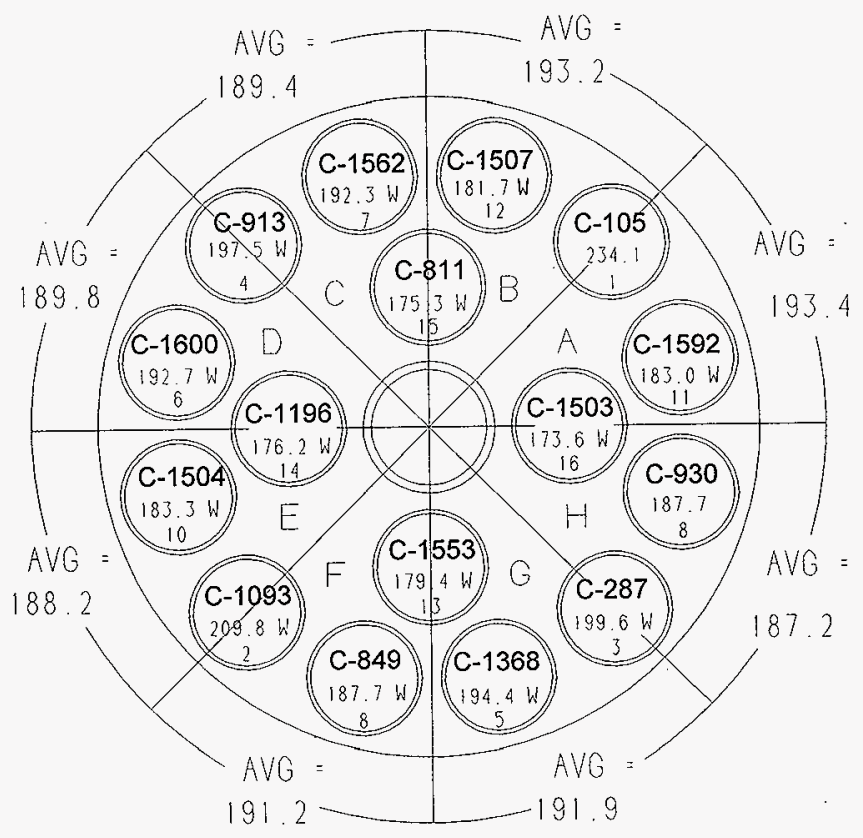




\subsection{QUALITY ASSURANCE}

\subsection{GENERAL}

This section describes the quality assurance $(Q A)$ requirements for the onetime onsite transportation of 16 cesium chloride capsules overpacked in Type W overpacks in the BUSS Cask.

\subsection{GENERAL REQUIREMENTS}

The BUSS Cask has been demonstrated to contain a nearly identical payload in accordance with the requirements of 10 CFR 71 and documented in the SARP (SNL 1994). Therefore, no transportation hazard index (THI) or quality level (OL) (WHC-CM-2-14) is assigned to the BUSS Cask. As the BUSS Cask is a packaging that is certified (DOE 1996), the SARP (SNL. 1994) will be the guiding document for all $Q A$ activities that pertain directly to the cask. The new basket and Type $W$ overpack $Q A$ requirements are described below.

\subsection{ORGANIZATION}

The organizational structure and the assignment of responsibility shall be such that quality is achieved and maintained by those who have been assigned responsibility for performing work. Quality achievement is to be verified by persons or organizations not directly responsible for performing the work.

Packaging Engineering of Waste Management Federal Services, Inc., Northwest Operations (WMNW), WESF, and building 324 personnel are responsible for the quality of the work performed by their respective organizations and for performing the following activities.

- Follow current requirements of this SEP; the requirements of the BUSS Cask SARP (SNL 1994); WHC-CM-4-2, Quality Assurance Manual; and WHC-CM-2-14.

- Provide instructions for implementing $Q A$ requirements.

The responsible facility Quality Assurance manager is responsible for establishing and administering the Fluor Daniel Hanford, Inc. QA program as stated in WHC-CM-4-2.

\subsection{QA ACTIVITIES}

\subsubsection{Design Control}

All engineering change notices (ECNs) to the basket or Type W overpack design shall be approved by WESF and Packaging Engineering of WMNW as part of the process to verify the SEP is valid for the new configuration. 


\subsubsection{Procurement and Fabrication Control}

Procurement and fabrication of the basket and Type $W$ overpacks shall be in accordance with drawings $\mathrm{H}-2-828979$ and $\mathrm{H}-3-307504$, respectively. Requirements of WHC-CM-4-2 shall be followed as required by $\mathrm{QA}$ personnel performing the acceptance inspections after fabrication and the packaging Quality Assurance engineer.

\subsubsection{Control of Operation/Processes}

Processes affecting the quality of package items or services shall be controlled by instructions, procedures, drawings, checklists, or other appropriate means. These means shall ensure that process parameters are controlled within defined limits and that specified environmental conditions are maintained. Methods for defining how process controls will be applied are defined in WHC-CM-4-2.

\subsubsection{Control of Inspection and Testing}

Fabrication and acceptance inspections shall be performed to the following guidelines.

7.4.4.1 Inspection Personnel. Inspection for acceptance of items fabricated onsite shall be performed by qualified quality control (OC) personnel. inspection for acceptance of items fabricated offsite shall be performed by qualified OC personnel from Procurement Quality Assurance,

7.4.4.2 In-Process Inspection. Fabrication and acceptance inspections shall be performed by qualified $\mathrm{QC}$ personnel.

\subsubsection{Control of Operations and Maintenance}

Loading/unloading procedures shall be written by the user with appropriate reference to this SEP, the BUSS Cask SARP (SNL 1994) and WESF documentation to ensure adequate loading and operation of packaging. The loading/unloading procedure identifies actions required by loading personnel to safely and properly handle the BUSS Cask, its components, and the overpacked cesium chloride capsules. The loading/unloading procedures shall also identify which steps, as defined in this SEP (Part A, Section 6.0), are important to transportation safety.

The BUSS Cask maintenance shall be documented as required by the SARP. As this is a onetime shipment, no maintenance of the basket is anticipated.

\subsubsection{Test Control}

Leakage rate testing shall be done as required by the BUSS Cask SARP. Special form testing of the Type $W$ overpacks shall be documented separately. Any other testing required incident to fabrication shall be documented as required by WHC-CM-4-2.

\subsubsection{Control of Measuring and Test Equipment}

The requirements for measuring and test equipment contained in WHC-CM-4-2 shall apply to operations and maintenance activities, as described in Part A, Sections 6.0 and 8.0. 


\subsubsection{Control of Nonconforming Items}

Identification, documentation, evaluation, and disposition of nonconforming items and activities shall be accomplished per WHC-CM-4-2.

Items procured or fabricated for the packaging or used in the packaging shall be $\mathrm{QC}$ inspected as required by the BUSS Cask SARP. Other items shall be QC inspected prior to use for compliance with the purchase order, specification, and/or fabrication drawing. The cognizant engineer, with $Q A$ concurrence, shall define the acceptance criteria.

\subsubsection{Corrective Action}

Nonconformance or conditions adverse to quality are evaluated as described in Part A, Section 7.4.8, and the need for corrective action is determined in accordance with WHC-CM-4-2.

\subsubsection{QA Records and Document Control}

Records that furnish documentary evidence of quality shall be specified, prepared, and maintained per WHC-CM-4-2 and WHC-CM-3-5, Document Control and Records Management Manual: Controlled documents include (but are not limited to) the following: drawings, specifications, purchase orders, plans, procedures to inspect and test, reports, quality verification reports, nonconformance reports, corrective action reports, the SEP, and operational and maintenance procedures.

\subsubsection{Independent Assessments}

The Hanford independent assessment process is addressed in, and shall comply with, WHC-CM-4-2. 
HNF-SD-TP-SEP-065 Rev. 0

This page intentionally left blank.

A7-4 
HNF-SD-TP-SEP-065 Rev, 0

\subsection{MAINTENANCE}

All maintenance required by the BUSS Cask SARP (SNL 1994) shall be completed prior to transporting the capsules (Part A, Section 6.0).

No maintenance is anticipated for the basket to support this onetime use. If future uses are anticipated, the basket should be stored in a manner that precludes degradation of the basket structure.

Maintenance of the Type $W$ overpacks and capsules, except as required prior to transportation, is the responsibility of WESF and is beyond the scope of this document. 
This page intentionally left blank. 


\subsection{REFERENCES}

10 CFR 71, 1992, "Packaging and Transportation of Radioactive Materials," Code of Federal Regulations, as amended.

49 CFR 173, 1997, "Shippers--General Requirements for Shipments and Packagings," Code of Federal Regulations, as amended.

ANSI, 1989, Sealed Radioactive Sources, Classification, N43.6-1977 (formerly ANSI N542-1977), revised 1989, American National Standards Institute, New York, New York.

DOE, 1996, U.S. Department of Energy Certificate of Compliance for Radioactive Materials Packages, USA/9511/B(U) (DOE), Rev. 3, U.S. Department of Energy, Germantown, Maryland, August 27, 1996.

FDH-MD-001, Adoption of WHC Documents, Fluor Daniel Hanford, inc., Richland, Washington

SNL, 1994, Beneficial Uses Shipping System (BUSS) Cask Safety Analysis Report for Packaging (SARP), Volumes I and II, SAND83-0698 (TCC-0430), Rev. 5, Sandia National Laboratories, Albuquerque, New Mexico.

WHC-CM-2-14, Hazardous Material Packaging and Shipping, Westinghouse Hanford Company, Richland, Washington.

WHC-CM-3-5, Document Control and Records Management Manual, Westinghouse Hanford Company, Richland, Washington.

WHC-CM-4-2, Quality Assurance Manual, Westinghouse Hanford Company, Richland, Washington. 
HNF-SD-TP-SEP-065 ReV. O

This page intentionally left blank.

A9-2 


\subsection{APPENDIX: DRAWINGS}

Drawings H-3-307504, Cs Capsule Type W Overpack, and H-2-828979, BuSS Basket for 16 Type W CsCl Overpacked Capsules, are attached for reference only. At the writing of this SEP, several outstanding ECNs were not posted to these drawings. 
HNF-SD-TP-SEP-065 Rev. 0

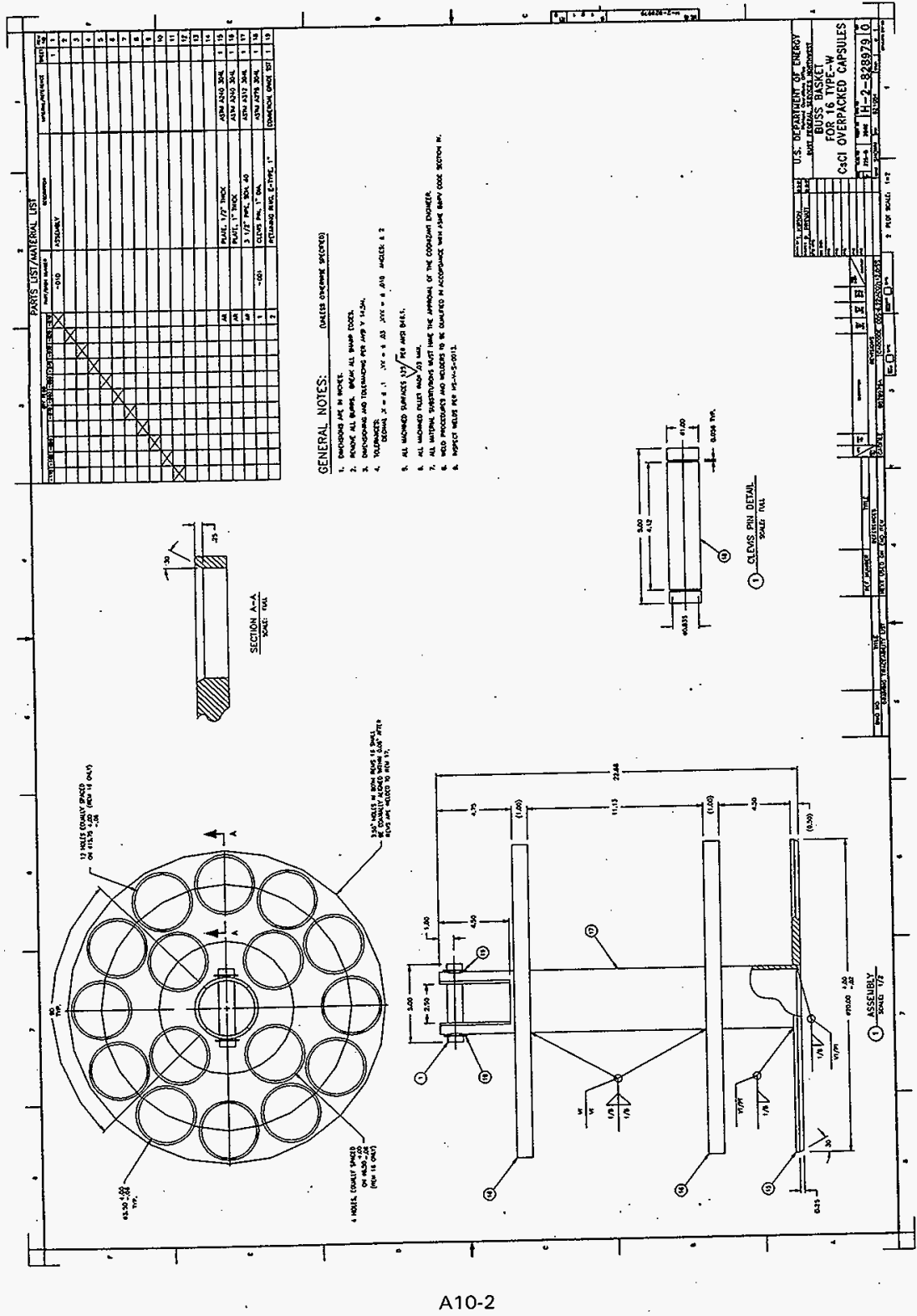


HNF-SD-TP-SEP-065 ReV. 0

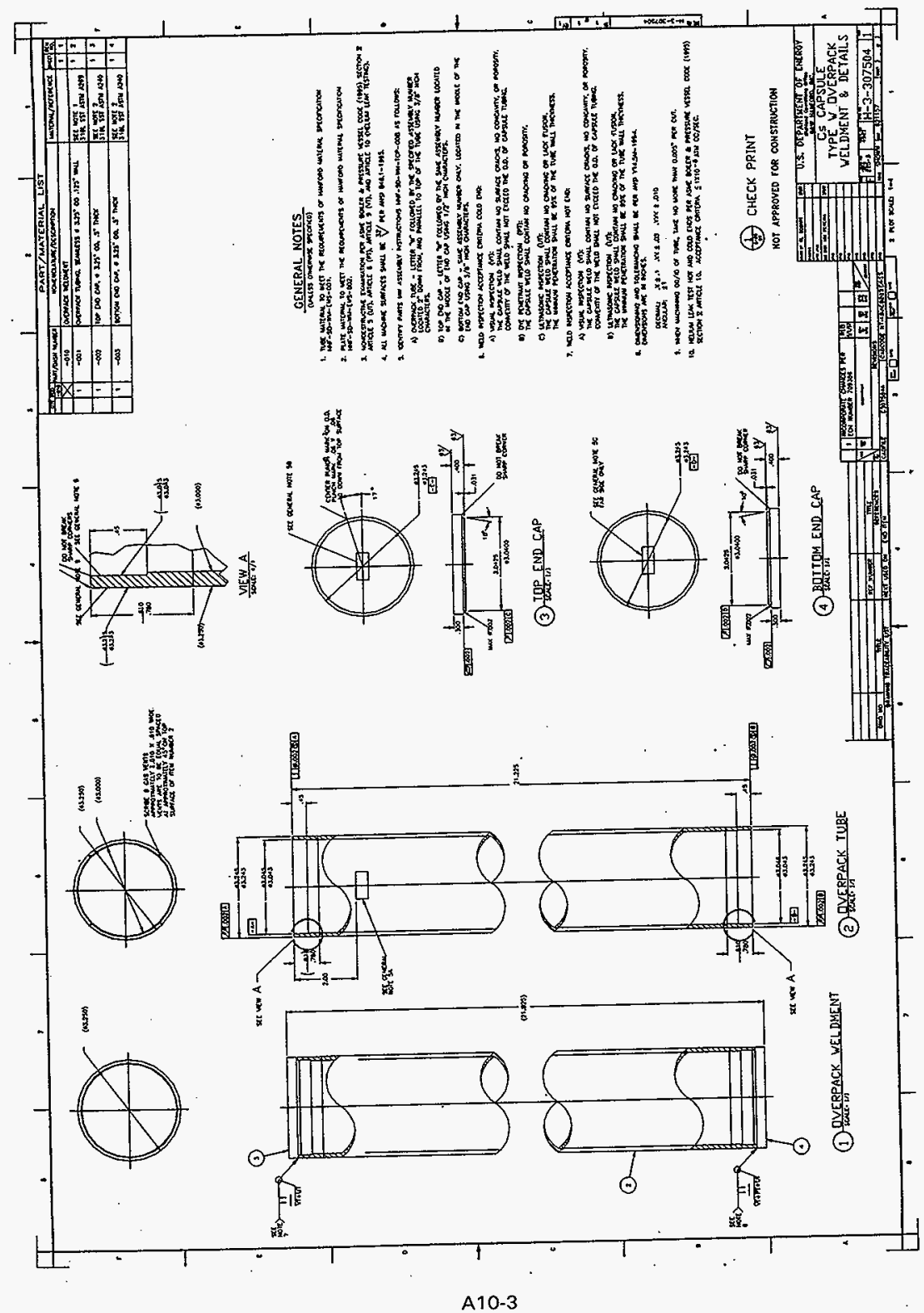


HNF-SD-TP-SEP-065 Rev. 0

This page left intentionally blank: 


\section{PART B: PACKAGE EVALUATION}

\subsection{INTRODUCTION}

This Safety Evaluation for Packaging (SEP) documents the evaluation of a new basket design and Type $W$ overpacked cesium chloride capsules for transport in the Beneficial Uses Shipping System (BUSS) Cask in accordance with the onsite transportation requirements of WHC-CM-2-14, Hazardous Material Packaging and Shipping. This design will support the onetime onsite shipment of 16 overpacked cesium chloride capsules from building 324, in the Hanford 300 Area, to building 224T, the Waste Encapsulation and Storage Facility (WESF), in the Hanford 200 East Area.

\subsection{EVALUATION SUMMARY AND CONCLUSIONS}

The BUSS Cask with a new basket is safe for the onsite shipment of 16 overpacked cesium chloride capsules, as described in Part A, Section 3.0 of this SEP, in accordance with the requirements of WHC-CM-2-14.

\subsubsection{Contents}

The contents shown in Part A, Section 3.0, were evaluated and found to be acceptable for transport using the basket shown in drawing $\mathrm{H}-2-828979$ (Part $A$, Section 10.0) and the Type $W$ overpacks shown in drawing $\mathrm{H}-3-307504$ (Part $\mathrm{A}$, Section 10.0 ).

\subsubsection{Radiological Risk}

A complete radiological risk analysis is not required since the SEP demonstrates that the contents will be contained during both normal conditions of transport (NCT) and hypothetical accident conditions (HAC) as defined by 10 CFR 71. The BUSS Safety Analysis Report for Packaging (SARP) demonstrates compliance with 10 CFR 71 and 49 CFR 173. Therefore, Part B, Section 3.0 of this SEP only demonstrates that the probability of a serious accident during transportation is sufficiently low to be considered incredible.

\subsubsection{Containment}

Containment is maintained by the payload throughout all NCT and HAC events. The containment evaluation is presented in Part B, Section 4.O.

\subsubsection{Shielding}

The shielding evaluation demonstrates that the 16 overpacked capsules can be transported in a manner consistent with as low as reasonably achievable (ALARA) practices. The shielding evaluation is presented in Part B, Section 5.0.

Subcriticality is not addressed since no fissile material is being transported. 


\subsubsection{Structural}

The structural adequacy of the cask, basket, and contents is demonstrated in Part B, Section 7.0, of this SEP.

\subsubsection{Thermal}

The thermal analysis presented in Part B, Section 8.0, of this SEP demonstrates that the overpacked capsules meet the thermal requirements for the BUSS Cask as defined in the SARP (SNL 1994).

\subsubsection{Gas Generation}

Gas generation is not addressed since no gas can be generated within the capsules or the cask. Additionally, as shown in Part $B$, Section 10.0, the pressure due to temperature increases is less than that analyzed in the HAC portion of the SARP (SNL 1994).

\subsection{REFERENCES}

10 CFR 71, 1992, "Packaging and Transportation of Radioactive Materials," Code of Federal Regulations, as amended.

49 CFR 173, 1997, "Shippers--General Requirements for Shipments and Packagings," Code of Federal Regulations, as amended.

SNL, 1994, Beneficial Uses Shipping System (BUSS) Cask Safety Analysis Report for Packaging (SARP), Volumes I and II, SAND83-0698 (TCC-0430), Rev. 5, Sandia National Laboratories, Albuquerque, New Mexico.

WHC-CM-2-14, Hazardous Material Packaging and Shipping, Westinghouse Hanford Company, Richland, Washington. 


\section{HNF-SD-TP-SEP-065 Rev. 0}

\subsection{CONTENTS EVALUATION}

The radioactive contents considered for this evaluation are listed in Part A, Section 3.0. These contents are well within the activity limits approved for transportation in the BUSS Cask SARP (SNL 1994).

\subsection{REFERENCE}

SNL, 1994, Beneficial Uses Shipping System (BUSS) Cask Safety Analysis Report for Packaging (SARP), Volumes I and II, SAND83-0698 (TCC-0430), Rev. 5, Sandia National Laboratories, Albuquerque, New Mexico. 
HNF-SD-TP-SEP-065 Rev. O

This page intentionally left blank. 


\subsection{RADIOLOGICAL RISK EVALUATION}

The containment boundary for the cesium chloride capsules which will be shipped in the BUSS Cask will be provided by the encapsulation of the capsules in Type $W$ overpacks as discussed in Part B, Section 4.0. However, as an additional demonstration of safety, a discussion is presented in this section which addresses the radiological risks associated with the shipment of the BUSS Cask containing singly-encapsulated cesium chloride capsules.

Onsite transportation safety requirements are outlined in WHC-CM-2-14 and Mercado (1994). The acceptability of risks associated with onsite shipments can be determined by a radiological risk evaluation which evaluates the probability and consequences of release. The potential consequences of a postulated release of the BUSS Cask contents, which may contain up to $31,450 \mathrm{Tbq}(850,000 \mathrm{Ci})$ of ${ }^{137} \mathrm{Cs}$, would clearly be unacceptable in any scenario. The potential consequences, therefore place the BUSS Cask shipments in the highest hazard category as outlined in Mercado (1994). The highest hazard category results in the most restrictive annual release frequency acceptance criterion of $10^{-7}$. As long as a risk evaluation demonstrates that the packaging will prevent release of the contents for any accident that occurs with a release frequency of greater than $10^{-7}$ per year, a detailed risk analysis is not performed. The radiological risk evaluation presented in this section demonstrates that the shipments meet the required criterion.

The BUSS Cask is a certified Type B packaging which is approved for the shipment of highway route controlled quantity (HRCO) nonfissile radioactive material. The BUSS Cask provides shielding and confinement (as defined in the BUSS Cask SARP [SNL 1994]), as well as impact, puncture, and thermal protection for doubly-encapsulated special form contents during NCT and HAC as defined in $10 \mathrm{CFR} 71$. Compliance with these requirements is documented in the BUSS Cask SARP (SNL 1994).

The SARP demonstrates that the cask body, lid, and impact limiters are virtualiy unaffected by being subjected to the NCT and HAC events specified in 10 CFR 71.71 and 10 CFR 71.73. Those conditions include a $30 \mathrm{ft}$ drop onto a hard unyielding surface, a puncture test, and immersion in an $800^{\circ} \mathrm{C}$ fire for 30 minutes. The BUSS Cask SARP relies on the special form encapsulated materials to provide containment. However, because the BUSS Cask structural members withstand HAC, protection of the payload is also being provided by the BUSS Cask body, lid, and impact limiters.

In a radiological risk evaluation the total conditional probability of failure of the packaging is multiplied by the frequency of accidents per year to arrive at an annual accident release frequency. If the annual accident release frequency is below the required criteria, which in this case is a frequency of $10^{-7}$ accident releases per year, the shipment meets onsite transportation safety requirements (Mercado 1994).

The Hanford Site truck accident rate for all trucks including vans and light-weight pick-up trucks is equal to $2.0 \times 10^{-7}$ accidents per mile (Green et al. 1996). The BUSS Cask will be used for one shipment of 25 miles which, when multiplied by the accident rate and reduction factor, gives a frequency of $5.0 \times 10^{-6}$ accidents per year. The accident frequency of $5.0 \times 10^{-6}$ is very conservative in that it does not take credit for the reduction factors which apply to accident rates for onsite transport. Such reduction factors are normally applied in detailed risk analyses.

The conditional release probabilities are based on the performance of the packaging and are taken from a study performed by Sandia National Laboratory (SNL) on the response of large casks to severe accidents (Dennis et al. 1976). The BUSS Cask is 12 in. thick and the probability of a release given a puncture event is approximately equal to zero. The cask will withstand a 30 minute 
$800^{\circ} \mathrm{C}$ fire; therefore the probability of a fire failure on the Hanford Site, where emergency responders have a 15 minute response time and are trained in the handling of radioactive material, is also approximately zero. In addition, based on the analysis presented in the BUSS Cask SARP, the BUSS Cask would not fail from the crush force of the trailer $(16,000 \mathrm{lb})$ should a roliover accident occur. Therefore, the probability of failure from the crush force would also be approximately equal to zero.

The only conditional release probability that will affect the annual accident release frequency is related to impact. The BUSS Cask SARP demonstrates that the cask will survive a $30 \mathrm{ft}$ drop onto a hard unyielding surface. If the very conservative assumption is made that the cask fails a $30 \mathrm{mph}$ velocity change onto concrete, given that the system has a gross vehicle weight of 35 tons, the corresponding total conditional release probability is 0.00612 (Dennis et al. 1976). When multiplied by the annual accident frequency of $5.0 \times 10^{-6}$, the resulting annual probability of release from failure by impact is $3.0 \times 10^{-8}$ which is below the required $10^{-7}$. In fact, 3 shipments can be made in one year and still meet the accident criterion of less than $10^{-7}$. Therefore, the BUSS Cask meets onsite transportation safety requirements and shipments of singly-encapsulated cesium chloride capsules in the BUSS Cask present no unacceptable risks to the worker or the public.

\subsection{REFERENCES}

10 CFR 71, 1992, "Packaging and Transportation of Radioactive Materials," Code of Federal Regulations, as amended.

49 CFR 173, 1997, "Shippers--General Requirements for Shipments and Packagings," Code of Federal Regulations, as amended.

Dennis, A. W., J. T. Foley, W. F. Hartman, and D. W. Larson, 1978, Severities of Transportation Accidents Involving Large Packages, SAND77-0001, Sandia National Laboratories, Albuquerque, New Mexico.

Green, J. R., B. D. Flanagan, and H. W. Harris, 1996, Hanford Site Truck Accident Rate, 19901995, WHC-SD-TP-RPT-021, Rev. 0, Westinghouse Hanford Company, Richland, Washington.

H\&R, 1995, Recommended Onsite Transportation Risk Management Methodology, H\&R522-1, H\&R Technical Associates, Inc., Oak Ridge, Tennessee.

Mercado, J. E., 1994, Report on Equivalent Safety for Transportation and Packaging of Radioactive Materials, WHC-SD-TP-RPT-001, Rev. 0, Westinghouse Hanford Company, Richland, Washington.

SNL, 1994, Beneficial Uses Shipping System (BUSS) Cask Safety Analysis Report for Packaging (SARP), Volumes I and II, SAND83-0698 (TCC-0430), Rev. 5, Sandia National Laboratories, Albuquerque, New Mexico.

WHC-CM-2-14, Hazardous Material Packaging and Shipping, Flour Daniel Hanford, Inc., Richland, Washington. 


\subsection{CONTAINMENT EVALUATION}

The containment boundary for this shipment is the Type $W$ overpack. Prior to shipment, additional testing will be conducted to demonstrate that capsules in the Type $W$ overpacks meet the special form requirements of 49 CFR 173 and American National Standards Institute (ANSI) N43.6, Sealed Radioactive Sources, Classification (ANSI 1989). The Type W overpacked capsules will not be certified as special form material.

The assembled Type W overpacks and capsules will be tested after assembly and must have demonstrate a leakage rate of less than or equal to $10^{-8}$ atm-cc/sec for acceptance.

The cask seal is designed to be leak-tight to $10^{-4} \mathrm{~atm}-\mathrm{cc} / \mathrm{sec}$ to retain the helium atmosphere during normal transportation. After an accident, the SARP (SNL 1994) demonstrates that there will be no permanent deformation of the cask seal and the cask will contain the capsules, but no leaktightness was demonstrated since helium does not have to be retained after an accident. As the overpacked capsules shall be leakage rate tested when assembled with the Type $W$ overpacks and the overpack design shall be tested to the special form criteria of 49 CFR 173 and ANSI N43.6, no leakage rate criteria is required for the BUSS Cask seal.

\subsection{REFERENCES}

49 CFR 173, 1997, "Shippers--General Requirements for Shipments and Packagings," Code of Federal Regulations, as amended.

ANSI, 1989, Sealed Radioactive Sources, Classification, N43.6-1977 (formerly ANS! N542-1977), revised 1989, American National Standards Institute, New York, New York.

SNL, 1994, Beneficial Uses Shipping System (BUSS) Cask Safety Analysis Report for Packaging (SARP), Volumes 1 and II, SAND83-0698 (TCC-0430), Rev. 5, Sandia National Laboratories, Albuquerque, New Mexico. 
Rev. 0

This page intentionally left blank. 


\subsection{SHIELDING EVALUATION}

\subsection{INTRODUCTION}

This shielding evaluation supports the shipment of overpacked cesium chloride capsules in the BUSS Cask. Although the BUSS Cask has already been approved for use for this application, this analysis was required due to the new basket design that will be used for this shipment.

This section also includes an evaluation of the fraction of heat deposited in various regions of the cask to support the thermal analysis for the cask.

\subsection{DIRECT RADIATION SOURCE SPECIFICATION}

\subsubsection{Gamma Source}

The BUSS SARP (SNL 1994) activity limit is $70 \mathrm{kCi}$ of ${ }^{137} \mathrm{Cs}$ per capsule, or a total of $1,120 \mathrm{kCi}$ when 16 capsules are loaded in the cask. The main radiological hazard associated with the capsules involves the $0.662 \mathrm{MeV}$ photon emitted during the decay of ${ }^{137 \mathrm{~m}} \mathrm{Ba}$. ${ }^{137 \mathrm{~m}} \mathrm{Ba}$ is produced during $94.6 \%$ of the decays of ${ }^{137} \mathrm{Cs}$. A $0.662 \mathrm{MeV}$ photon is emitted during $90 \%$ of the decays of ${ }^{137 \mathrm{~m}} \mathrm{Ba}$. This results in a photon emission rate of $3.53 \times 10^{16}$ photons $/ \mathrm{s}$ for $1,120 \mathrm{kCi}$ of ${ }^{137} \mathrm{Cs}$, as shown below.

$$
\begin{aligned}
\text { Photon Emission Rate }= & \begin{array}{l}
1,120,000(\mathrm{Ci}) \times 3.7 \mathrm{E} 10\left(\text { decays } / \mathrm{s} / \mathrm{Ci} \text { of }{ }^{137} \mathrm{Cs}\right) \times 0.946\left({ }^{137 \mathrm{~m}} \mathrm{Ba}\right. \\
\text { atoms } \left.\left./ \text { decay of }{ }^{137} \mathrm{Cs}\right) \times 0.9 \text { (photons } / \text { decay of }{ }^{137 \mathrm{~m}} \mathrm{Ba}\right)
\end{array} \\
\text { Photon Emission Rate }= & 3.53 \times 10^{16} \text { photons } / \mathrm{s}(0.662 \mathrm{MeV})
\end{aligned}
$$

\subsubsection{Beta Source}

The beta source leads to an insignificant dose rate outside of the cask because of the shielding provided by the cask. This shielding is described in Part B, Section 5.4.3.

\subsubsection{Neutron Source}

The WESF capsules contain no neutron emitters. Therefore, the neutron dose rates are not reported.

\subsection{SUMMARY OF SHIELDING PROPERTIES OF MATERIALS}

The shielding attenuation properties for the bulk materials used in this analysis were obtained from the Monte Carlo N-Particle (MCNP) computer code data library (Breismeister 1993, Carter 1995). A description of the configuration and densities of the shielding materials used in the calculational models is given in Part B, Section 5.4.3. 


\subsection{NORMAL CONDITIONS OF TRANSPORT}

\subsubsection{Conditions to be Evaluated}

Dose rates will be evaluated at the cask surface and $2 \mathrm{~m}$ from the cask. The dose rate at $2 \mathrm{~m}$ is conservatively assumed to be the driver position and conservatively used for the dose rate at $2 \mathrm{~m}$ from the vehicle surface.

\subsubsection{Acceptance Criteria}

The BUSS Cask is normally shipped using the exclusive use criteria of 49 CFR 173; therefore, the same criteria shall be applied to this evaluation. The exclusive use criteria is a maximum of $10 \mathrm{mSv} / \mathrm{h}(1000 \mathrm{mrem} / \mathrm{h})$ on any surface of the cask, $2 \mathrm{mSv} / \mathrm{h}(200 \mathrm{mrem} / \mathrm{h})$ at the vehicle surface, $0.1 \mathrm{mSv} / \mathrm{h}(10 \mathrm{mrem} / \mathrm{h})$ at $2 \mathrm{~m}$ from the vehicle surface, and $0.02 \mathrm{mSv} / \mathrm{h}(2 \mathrm{mrem} / \mathrm{h})$ in any normally occupied space for non-radiological workers.

\subsubsection{Shielding Mode!}

The MCNP computer code (Breismeister 1993, Carter 1995) was used for the gamma-ray dose rate calculations. MCNP is a three-dimensional monte carlo computer code and uses Evaluated Nuclear Data Files (ENDF/B) for cross sections (BNL 1991). The ENDF/B system is maintained by the National Nuclear Data Center at Brookhaven National Laboratory under contract from the U.S. Department of Energy (DOE). The quality assurance (OA) documentation of MCNP for use at the Hanford Site is given in Carter (1996). Fluence-to-dose conversion factors were conservatively based on an anterior-to-posterior irradiation pattern (ANSI/ANS .1991) and are listed in Table B5-1.

The gamma source term (see Part B, Section 5.2.1) was assumed to be homogeneously distributed throughout the volume of the 16 capsules. The capsules were modeled as cesium chloride with a density of $2.6 \mathrm{~g} / \mathrm{cc}$. Note that no credit was taken for the $10.2 \mathrm{~cm}(4 \mathrm{in}$.) fins on the side of the cask. Tables B5-2 and B5-3 summarize the radial and axial geometry and material composition, respectively. Figures $\mathrm{B} 5-1$ and $\mathrm{B} 5-2$ are simplified radial and axial models, respectively.

\subsubsection{Shielding Calculations}

Table B5-4 summarizes the gamma dose rate estimates from MCNP for various distances from the BUSS Cask. 
Table B5-1. ANSI/ANS (1991) Photon Fluence to Dose Conversion Factors.

\begin{tabular}{|c|c|c|c|}
\hline Energy (MeV) & $\begin{array}{c}\text { Flux to dose rate } \\
(\mathrm{mrem} / \mathrm{h}) /\left(\mathrm{photon} / \mathrm{cm}^{2} / \mathrm{s}\right)\end{array}$ & Energy (MeV) & $\begin{array}{c}\text { Flux to dose rate } \\
(\mathrm{mrem} / \mathrm{h}) /\left(\mathrm{photon} / \mathrm{cm}^{2} / \mathrm{s}\right)\end{array}$ \\
\hline $1.00 \mathrm{E}-02$ & $2.232 \mathrm{E}-05$ & $5.00 \mathrm{E}-01$ & $9.144 \mathrm{E}-04$ \\
\hline $1.50 \mathrm{E}-02$ & $5.625 \mathrm{E}-05$ & $6.00 \mathrm{E}-01$ & $1.076 \mathrm{E}-03$ \\
\hline $2.00 \mathrm{E}-02$ & $8.568 \mathrm{E}-05$ & $8.00 \mathrm{E}-01$ & $1.379 \mathrm{E}-03$ \\
\hline $3.00 \mathrm{E}-02$ & $1.184 \mathrm{E}-04$ & $1.00 \mathrm{E}+00$ & $1.656 \mathrm{E}-03$ \\
\hline $4.00 \mathrm{E}-02$ & $1.314 \mathrm{E}-04$ & $1.50 \mathrm{E}+00$ & $2.246 \mathrm{E}-03$ \\
\hline $5.00 \mathrm{E}-02$ & $1.382 \mathrm{E}-04$ & $2.00 \mathrm{E}+00$ & $2.758 \mathrm{E}-03$ \\
\hline $6.00 \mathrm{E}-02$ & $1.440 \mathrm{E}-04$ & $3.00 \mathrm{E}+00$ & $3.672 \mathrm{E}-03$ \\
\hline $8.00 \mathrm{E}-02$ & $1.624 \mathrm{E}-04$ & $4.00 \mathrm{E}+00$ & $4.500 \mathrm{E}-03$ \\
\hline $1.00 \mathrm{E}-01$ & $1.919 \mathrm{E}-04$ & $5.00 \mathrm{E}+00$ & $5.292 \mathrm{E}-03$ \\
\hline $1.50 \mathrm{E}-01$ & $2.797 \mathrm{E}-04$ & $6.00 \mathrm{E}+00$ & $6.012 \mathrm{E}-03$ \\
\hline $2.00 \mathrm{E}-01$ & $3.708 \mathrm{E}-04$ & $8.00 \mathrm{E}+00$ & $7.488 \mathrm{E}-03$ \\
\hline $3.00 \mathrm{E}-01$ & $5.616 \mathrm{E}-04$ & $1.00 \mathrm{E}+01$ & $8.892 \mathrm{E}-03$ \\
\hline $4.00 \mathrm{E}-01$ & $7.416 \mathrm{E}-04$ & $1.20 \mathrm{E}+01$ & $1.040 \mathrm{E}-02$ \\
\hline
\end{tabular}

ANS = American Nuclear Society.

ANSI = American National Standards Institute.

ANSI/ANS, 1991, Neutron and Gamma-ray Fluence-to-dose Factors, ANSI/ANS-6.1.1-1991, American National Standards Institute/American Nuclear Society, New York, New York.

Table B5-2. BUSS Cask Radial Geometry and Material Composition.

\begin{tabular}{|l|c|c|}
\hline \multicolumn{1}{|c|}{ Zone (material) } & Outer radius (cm) & Material density $(\mathrm{g} / \mathrm{cc})$ \\
\hline Source (cesium chloride) & 2.512 & 2.6 \\
\hline Inner capsule (steel) & 2.858 & 8.0 \\
\hline Gap (air) & 2.990 & $1.22 \mathrm{E}-3$ \\
\hline Outer capsule (steel) & 3.335 & 8.0 \\
\hline Gap (helium) & 3.896 & $1.78 \mathrm{E}-4$ \\
\hline Type S overpack (steel)* & 4.445 & 8.0 \\
\hline BusS Cask inner radius & 25.718 & $\mathrm{NA}$ \\
\hline BUSS Cask (steel) & 58.738 & 8.0 \\
\hline
\end{tabular}

BUSS = Beneficial Uses Shipping System.

*The Type S overpack was used for the shielding model. The configuration of this overpack is functionally equivalent to the Type $W$ overpack for shielding. 
HNF-SD-TP-SEP-065 Rev. 0

Table B5-3. BUSS Axial Geometry and Material Composition.

\begin{tabular}{|l|c|c|}
\hline \multicolumn{1}{|c|}{ Zone (material) } & $\begin{array}{c}\text { Thickness } \\
(\mathrm{cm})\end{array}$ & $\begin{array}{c}\text { Material density } \\
(\mathrm{g} / \mathrm{cc})\end{array}$ \\
\hline BuSS Cask top (steel) & 32.893 & 8.0 \\
\hline Overpack top (steel) & 0.691 & 8.0 \\
\hline Gap (helium) & 2.261 & $1.78 \mathrm{E}-4$ \\
\hline Outer capsule top (steel) & 1.016 & 8.0 \\
\hline Gap (air) & 0.319 & $1.22 \mathrm{E}-3$ \\
\hline Inner capsule top (steel) & 1.016 & 8.0 \\
\hline Source (cesium chloride) & 48.068 & 2.6 \\
\hline Inner capsule bottom (steel) & 1.016 & 8.0 \\
\hline Gap (air) & 0.319 & $1.22 \mathrm{E}-3$ \\
\hline Outer capsule bottom (steel) & 1.016 & 8.0 \\
\hline Gap (helium) & 2.261 & $1.78 \mathrm{E}-4$ \\
\hline Overpack bottom (steel) & 0.691 & 8.0 \\
\hline BuSS Cask bottom (steel) & 32.893 & 8.0 \\
\hline
\end{tabular}

BUSS = Beneficial Uses Shipping System. 
Figure B5-1. Simplified Radial Sketch of BUSS Cask.

(Note: all dimensions in inches)

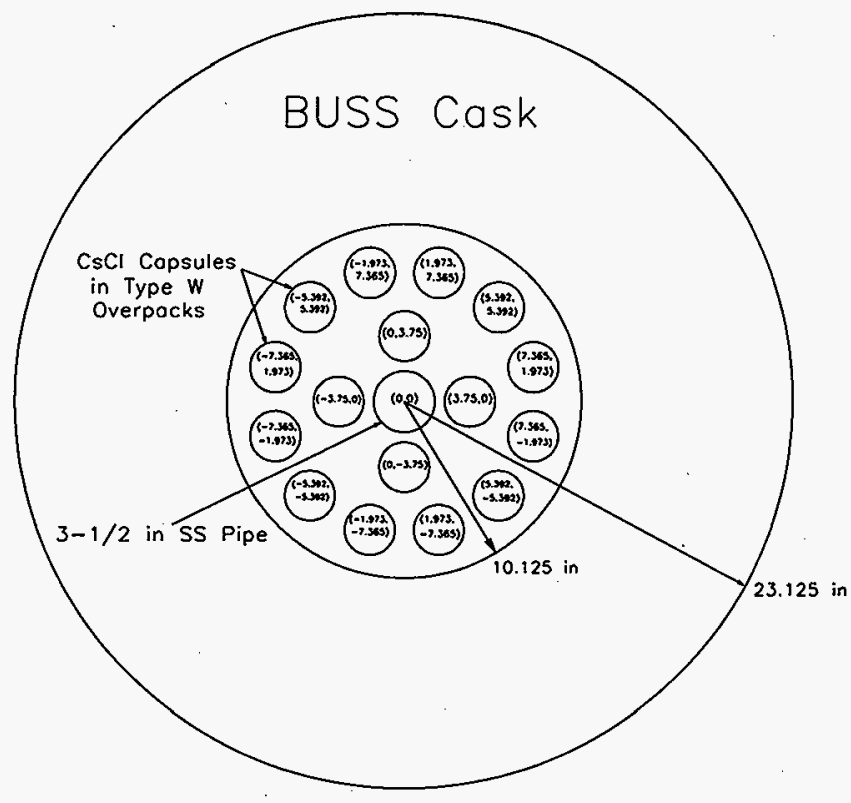


HNF-SD-TP-SEP-065 Rev. 0

Figure B5-2. Simplified Axial Sketch of BUSS Cask.

(Note: all dimensions in inches)

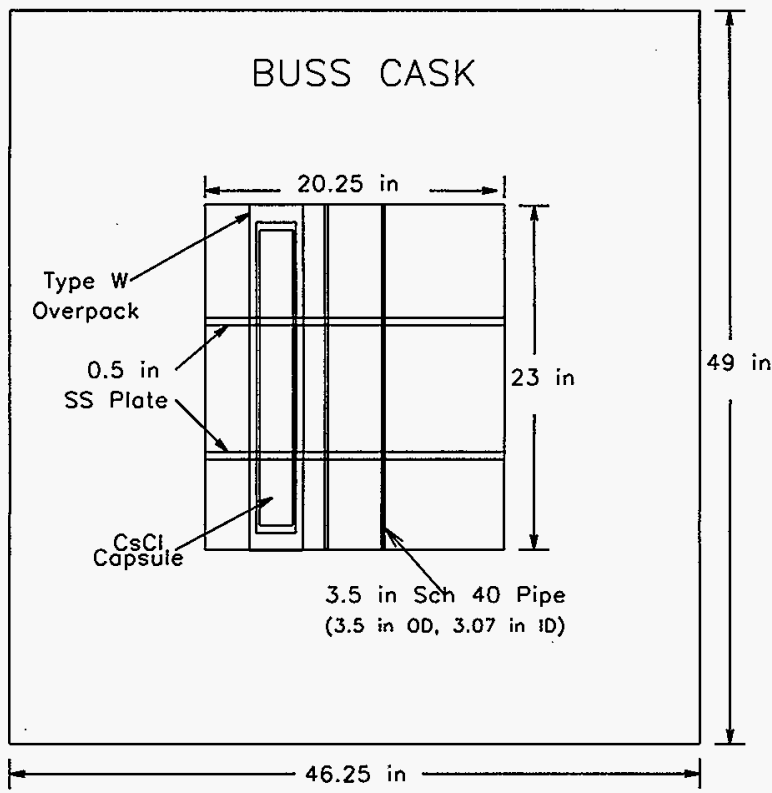

Table B5-4. Dose Rates for the BUSS Cask.

\begin{tabular}{|c|c|c|c|}
\hline \multicolumn{2}{|c|}{ Detector location } & $\begin{array}{c}\text { Limit, msv/h } \\
(\mathrm{mrem} / \mathrm{h})\end{array}$ & $\mathrm{mSv} / \mathrm{h}(\mathrm{mrem} / \mathrm{h})$ \\
\hline \multirow{2}{*}{ Cask surface } & Side & $2(200)$ & $0.21(21)$ \\
\cline { 2 - 4 } & Top & $2(200)$ & $0.42(42)$ \\
\hline \multirow{2}{*}{$2 \mathrm{~m}$ from side of cask } & $0.1(10)$ & $0.0081(0.81)$ \\
\hline Driver position (assumed to be at $2 \mathrm{~m})$ & $0.02(2)$ & $0.0081(0.81)$ \\
\hline
\end{tabular}

1 Sievert $=100$ rem.

BUSS = Beneficial Uses Shipping System. 


\subsection{ACCIDENT CONDITIONS}

\subsubsection{Conditions to be Evaluated}

Testing was performed on the BUSS Cask and it was found that there was no permanent deformation even after a $9 \mathrm{~m}$ ( $30 \mathrm{ft}$ ) drop test. Therefore, there is no credible scenario that could occur during onsite shipment of the BUSS Cask that would result in the loss of the cask lid or the loss of any shielding provided by the cask.

\subsubsection{Acceptance Criteria}

The external dose rate shall not exceed $10 \mathrm{mSv} / \mathrm{h}(1000 \mathrm{mrem} / \mathrm{h})$ at $1 \mathrm{~m}$ from the surface under accident conditions, as directed by the onsite transportation safety program.

\subsubsection{Shielding Model}

No credible accident scenario was identified; therefore, no shielding model was developed.

\subsection{SHIELDING EVALUATION AND CONCLUSIONS}

Table B5-5 summarizes the results of the shielding analysis along with the dose rate limits. The calculated dose rates are all well within the dose rate limits assuming the worst-case cask inventory of 16 capsules with $70 \mathrm{kCi}$ per capsule. Note that the dose rate at $2 \mathrm{~m}$ from the side of the cask was conservatively used for the dose rate at $2 \mathrm{~m}$ from the vehicle surface and the driver position.

Table B5-5. Dose Rates for the BUSS Cask.

\begin{tabular}{|c|c|c|c|}
\hline \multicolumn{2}{|c|}{ Detector location } & $\begin{array}{c}\text { Limit, mSv/h } \\
(\mathrm{mrem} / \mathrm{h})\end{array}$ & $\mathrm{mSv} / \mathrm{h}(\mathrm{mr} r \mathrm{~m} / \mathrm{h})$ \\
\hline \multirow{2}{*}{ Cask surface } & Side & $2(200)$ & $0.21(21)$ \\
\cline { 2 - 4 } & Top & $2(200)$ & $0.42(42)$ \\
\hline 2 m from side of cask & $0.1(10)$ & $0.0081(0.81)$ \\
\hline Driver position (assumed to be at $2 \mathrm{~m})$ & $0.02(2)$ & $0.0081(0.81)$ \\
\hline
\end{tabular}

1 Sievert $\doteq 100$ rem.

BUSS = Beneficial Uses Shipping System.

\subsection{EVALUATION OF THE THERMAL DEPOSITION FRACTIONS FOR THE CASK}

The redesigned basket required a reevaluation of the fraction of the heat deposited in various regions of the cask/contents. The MCNP computer code was used to estimate the fraction of energy deposited in various regions in the cask that is associated with the gamma rays emitted by 
the cesium chloride capsules. The energy associated with beta particles and internal conversion electrons during decay of ${ }^{137} \mathrm{Cs}$ and ${ }^{137 \mathrm{~m}} \mathrm{Ba}$ must also be accounted for. These items are discussed below.

${ }^{137} \mathrm{Cs}$ decays to ${ }^{137 \mathrm{~m}} \mathrm{Ba} 94.6 \%$ of the time by emission of a beta particle with a maximum energy of $0.5116 \mathrm{MeV}$ and an average energy of $0.173 \mathrm{MeV}$ (ICRP 1983 ). ${ }^{137} \mathrm{Cs}$ decays directly to ${ }^{137} \mathrm{Ba}$ (stable) the other $5.4 \%$ of the time by emission of a beta particle with a maximum energy of $1.1732 \mathrm{MeV}$ and an average energy of $0.425 \mathrm{MeV}$ (ICRP 1983). ${ }^{137 \mathrm{~m}} \mathrm{Ba}$ decays to ${ }^{137} \mathrm{Ba}$ (stable) $90 \%$ of the time by emission of a $0.662 \mathrm{MeV}$ gamma ray, and by internal conversion the other $10 \%$ of the time (ICRP 1983). Therefore, each decay of ${ }^{137} \mathrm{Cs}$ results in the production of 0.85 gamma rays with an energy of $0.662 \mathrm{MeV}$, the deposition of $0.187 \mathrm{MeV}(0.946 \times 0.173 \mathrm{MeV}+$ $0.054 \times 0.425 \mathrm{MeV}$ ) of energy from beta decay, and the deposition of $0.063 \mathrm{MeV}$ of energy from internal conversion. It is assumed that all of the energy associate with beta decay and internal conversion electrons is absorbed in the cesium chloride capsule. The remaining energy from the $0.662 \mathrm{MeV}$ gamma rays is distributed throughout the cask, although a small portion escapes the cask. The energy from the beta particles and internal conversion $\left(0.25 \mathrm{MeV}\right.$ per ${ }^{137} \mathrm{Cs}$ decay) must be added to the energy deposited in the cesium chloride by the gamma rays to obtain the total amount of energy deposited in the cesium chloride.

Small modifications were made to the MCNP model developed for the shielding analysis to estimate the thermal deposition fractions for various regions of the cask. The MCNP tally 6 option was used to estimate the energy deposition $(\mathrm{MeV} / \mathrm{g})$ averaged over a cell. The mass of the cell $(\mathrm{g})$, as calculated by MCNP, was then multiplied by the energy deposition for the cell to determine the total energy deposited in that cell. Table B5-6 summarizes the results along with the fraction of the total energy deposited in each of the cask regions. This table indicates that approximately $2.4 \%$ of the total energy is deposited outside of the BUSS Cask.

Note that in Table B5-6, the energy deposited in the cesium chloride from beta decay and internal conversion electrons was added to the energy deposited by the gamma rays as calculated by MCNP. This information will be used in the thermal analysis for the cask. 
Table B5-6. Summary of Energy Deposition in the BUSS Cask.

\begin{tabular}{|l|l|l|c|c|c|}
\hline \multicolumn{1}{|c|}{ Region } & \multicolumn{1}{|c|}{$\begin{array}{c}\text { MCNP } \\
\text { Cell No. }\end{array}$} & \multicolumn{1}{|c|}{$\begin{array}{c}\text { Mass } \\
(\mathrm{g})\end{array}$} & $\begin{array}{c}\text { Average energy } \\
\text { deposition } \\
(\mathrm{MeV} / \mathrm{g})\end{array}$ & $\begin{array}{c}\text { Energy } \\
\text { deposition } \\
(\mathrm{MeV})\end{array}$ & $\begin{array}{c}\text { Percent deposited } \\
\text { in region } \\
(\%)\end{array}$ \\
\hline Cesium chloride source $^{\mathrm{a}}$ & 1 & $2.5 \mathrm{E}+03$ & $8.0 \mathrm{E}+11$ & $1.2 \mathrm{E}+16$ & 36.5 \\
\hline Inner capsule $^{\mathrm{a}}$ & 2 & $2.7 \mathrm{E}+03$ & $5.2 \mathrm{E}+11$ & $1.4 \mathrm{E}+15$ & 4.1 \\
\hline Outer capsule $^{\mathrm{a}}$ & 4 & $3.4 \mathrm{E}+03$ & $5.7 \mathrm{E}+11$ & $1.9 \mathrm{E}+15$ & 5.7 \\
\hline Overpack $^{8}$ & 6 & $7.3 \mathrm{E}+03$ & $7.0 \mathrm{E}+11$ & $5.1 \mathrm{E}+15$ & 15.1 \\
\hline Center pipe & 23 & $7.9 \mathrm{E}+03$ & $7.7 \mathrm{E}+10$ & $6.1 \mathrm{E}+14$ & 1.8 \\
\hline Top support plate & 24,25 & $1.1 \mathrm{E}+04$ & $7.1 \mathrm{E}+10$ & $7.9 \mathrm{E}+14$ & 2.3 \\
\hline Bottom support plate & 26,27 & $1.1 \mathrm{E}+04$ & $7.1 \mathrm{E}+10$ & $7.8 \mathrm{E}+14$ & 2.3 \\
\hline Cask top & 34 & $2.6 \mathrm{E}+06$ & $5.3 \mathrm{E}+08$ & $1.4 \mathrm{E}+15$ & 4.1 \\
\hline Cask side & 35 & $3.7 \mathrm{E}+06$ & $2.0 \mathrm{E}+09$ & $7.2 \mathrm{E}+15$ & 21.4 \\
\hline Cask bottom & 36 & $2.6 \mathrm{E}+06$ & $5.3 \mathrm{E}+08$ & $1.4 \mathrm{E}+15$ & 4.1 \\
\hline Total & & & & $3.3 \mathrm{E}+16$ & 97.6 \\
\hline
\end{tabular}

BUSS $=$ Beneficial Uses Shipping System.

Includes all 16 cesium chloride capsules.

\subsection{REFERENCES}

ANSI/ANS, 1991, Neutron and Gamma-ray Fluence-to-dose Factors, ANSI/ANS-6.1.1-1991, American National Standards Institute/American Nuclear Society, New York, New York.

Breismeister, J. F., Editor, 1993, MCNP--A General Monte Carlo Code N-Particle Transport Code, Version 4a, LA-12625, Los Alamos National Laboratory, Los Alamos, New Mexico.

Carter, L. L., 1995, Certification of MCNP Version 4A for WHC Computer Platforms,

WHC-SD-MP-SWD-30001, Rev. 7, Westinghouse Hanford Company, Richland, Washington.

ICRP, 1987, International Commission on Radiological Protection, Data for Use in Protection Against External Radiation, Publication 57, International Commission on Radiological Protection, New York, New York.

ICRP, 1983, Radionuclide Transformations Energy and Intensity of Emissions, Publication 38, International Commission on Radiological Protection, New York, New York.

Nelson, J. V., 1996, Estimation of Neutron Dose Rates from Nuclear Waste Packages, (internal memo 8M730-JVN-96-007 to J. R. Green, March 8), Westinghouse Hanford Company, Richland, Washington.

SNL, 1994, Beneficial Uses Shipping System (BUSS) Cask Safety Analysis Report for Packaging (SARP), Volumes I and II, SAND83-0698 (TCC-0430), Rev. 5, Sandia National Laboratories, Albuquerque, New Mexico. 


\subsection{APPENDICES}

\subsubsection{MCNP Input File for Shielding Model}

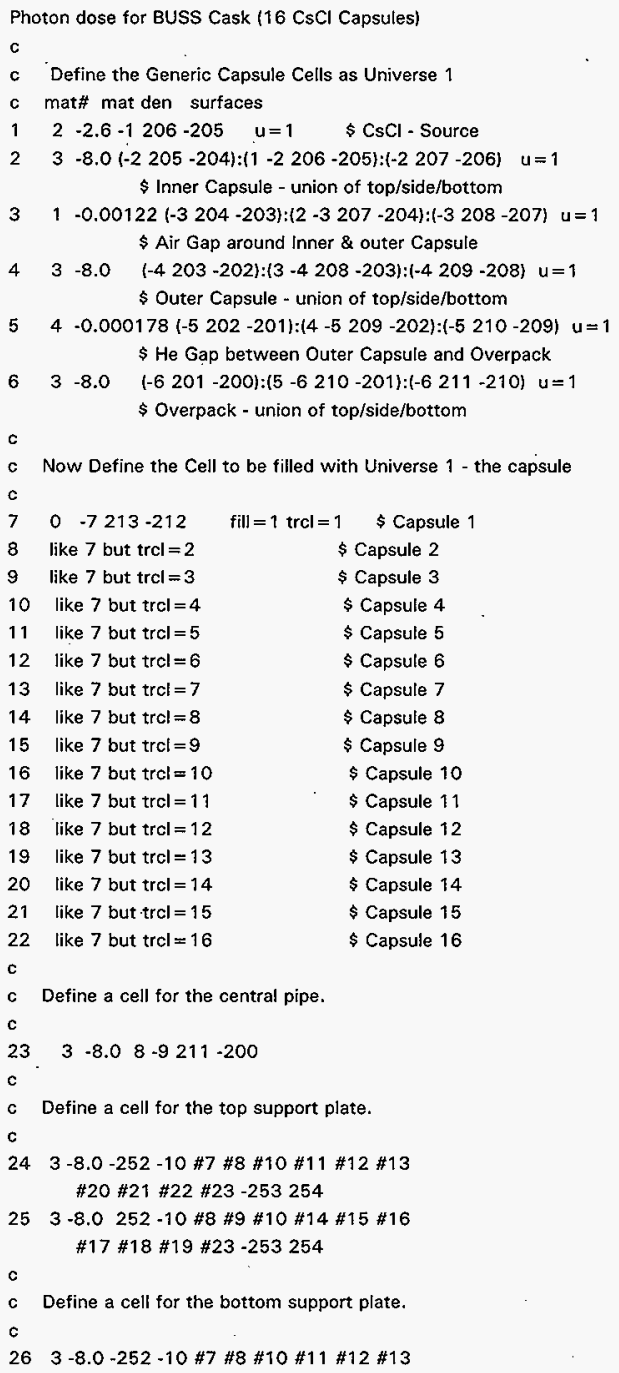


$\# 20 \# 21 \# 22 \# 23-255256$

$27 \quad 3-8.0 \quad 252-10 \# 8 \# 9 \# 10 \# 14 \# 15 \# 16$

$\# 17 \# 18 \# 19 \# 23-255256$

c

c Define a cell for air inside the cask source region.

c

$281-0.00122-252-10 \# 7 \# 8 \# 10 \# 11 \# 12 \# 13$

\#20 \#21 \#22 \#23 $253-200 \$$ Air around overpacks - Above top plate

$291-0.00122252-10 \# 8 \# 9 \# 10 \# 14 \# 15 \# 16$

$\# 17 \# 18 \# 19 \# 23253-200 \$$ Air around overpacks - Above top plate

$301-0.00122-252-10 \# 7 \# 8 \# 10 \# 11 \# 12 \# 13$

$\# 20 \# 21 \# 22$ \#23 $255-254$

$\$$ Air around overpacks - Between top/bottom plates

$31 \quad 1-0.00122252-10 \# 8 \# 9 \# 10 \# 14 \# 15 \# 16$

\#17 \#18\#19 \#23.255 -254

$\$$ Air around overpacks - Between top/bottom plates

$321-0.00122-252-10 \# 7 \# 8 \# 10 \# 11 \# 12 \# 13$

\#20\#21 \#22 \#23 211 -256 \$ Air around overpacks-Below bottom plate

$33 \quad 1-0.00122252-10 \# 8 \# 9 \# 10 \# 14 \# 15 \# 16$

\#17\#18\#19\#23 211-256 \$ Air around overpacks-Below bottom plate

c

c Now define cells for the cask.

c

$34 \quad 3-8.0-26200-235$. \$ Cask top

$\begin{array}{lllllllll}341 & 3 & -8.0 & -26 & 235 & -234 & \text { \$ Cask top }\end{array}$

$\begin{array}{llllll}35 & 3 & -8.0 & -26 & 234 & -233\end{array}$ \$ Cask top

$\begin{array}{lllllll}36 & 3 & -8.0 & -26 & 233 & -232 & \text { \$ Cask top }\end{array}$

$\begin{array}{lllllll}37 & 3 & -8.0 & -26 & 232 & -231 & \text { \$ Cask top }\end{array}$

$\begin{array}{llllllllll}38 & 3 & -8.0 & -26 & 231 & -230 & \$ \text { Cask top }\end{array}$

$\begin{array}{lllllll}39 & 3 & -8.0 & -26 & 230 & -229 & \text { \$ Cask top }\end{array}$

$\begin{array}{lllllll}40 & 3 & -8.0 & -26 & 229 & -228 & \text { \$ Cask top }\end{array}$

$413-8.0 \quad-26228-227$ \$ Cask top

$42 \quad 3 \quad-8.0-26227-226 \quad$ \$ Cask top

$43 \quad 3 \quad-8.0-26226-225 \quad$ \$ Cask top

$\begin{array}{lllllll}44 & 3 & -8.0 & -26 & 225 & -224 & \text { \$.Cask top }\end{array}$

$\begin{array}{lllllll}45 & 3 & -8.0 & -26 & 224 & -223 & \text { \$ Cask top }\end{array}$

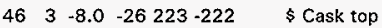

$\begin{array}{llllll}47 & 3 & -8.0 & -26 & 222 & -221\end{array}$ \$ Cask top

$\begin{array}{llllll}48 & 3 & -8.0 & -26 & 221 & -220\end{array}$ \$ Cask top

$\begin{array}{lllllll}49 & 3 & -8.0 & -26 & 236 & -211 & \$ \text { Cask bottom }\end{array}$

$\begin{array}{lllllll}50 & 3 & -8.0 & -26 & 237 & -236 & \$ \text { Cask bottom }\end{array}$

$\begin{array}{lllllll}51 & 3 & -8.0 & -26 & 238 & -237 & \$ \text { Cask bottom }\end{array}$

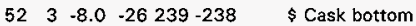

$\begin{array}{llllll}53 & 3 & -8.0 & -26 & 240 & -239\end{array}$ \$ Cask bottom

$\begin{array}{lllllll}54 & 3 & -8.0 & -26 & 241 & -240\end{array}$ \$ Cask bottom

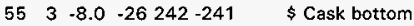

$\begin{array}{lllllll}56 & 3 & -8.0 & -26 & 243 & -242 \quad \$ \text { Cask bottom }\end{array}$

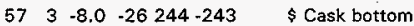

$\begin{array}{llllll}58 & 3 & -8.0 & -26 & 245 & -244\end{array}$ \$ Cask bottom

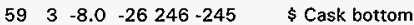

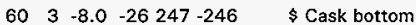

$\begin{array}{llllll}61 & 3 & -8.0 & -26 & 248 & -247\end{array}$ \$ Cask bottom

$62 \quad 3 \quad-8.0 \quad-26 \quad 249-248$ \$ Cask bottom

$\begin{array}{lllllll}63 & 3 & -8.0 & -26 & 250 & -249 & \text { \$ Cask bottom }\end{array}$ 


\begin{tabular}{|c|c|c|c|}
\hline 3 & -8.0 & $-26251-250$ & $\$$ Cask bottom \\
\hline 3 & -8.0 & $10-11-200211$ & $\$$ Cask side \\
\hline 3 & -8.0 & $11-12-200211$ & \$ Cask side \\
\hline 3 & -8.0 & $12-13-200211$ & \$ Cask side \\
\hline 3 & -8.0 & $13-14-200211$ & $\$$ Cask side \\
\hline 3 & -8.0 & $14-15-200211$ & \$ Cask side \\
\hline 3 & -8.0 & $15-16-200211$ & $\$$ Cask side \\
\hline 3 & -8.0 & $16-17-200211$ & \$ Cask side \\
\hline 3 & -8.0 & $17-18-200211$ & $\$$ Cask side \\
\hline 3 & -8.0 & $18-19-200211$ & $\$$ Cask side \\
\hline 3 & -8.0 & $19-20-200211$ & $\$$ Cask side \\
\hline 3 & -8.0 & $20-21-200211$ & $\$$ Cask side \\
\hline 3 & -8.0 & $21-22-200211$ & $\$$ Cask side \\
\hline 3 & -8.0 & $22-23-200211$ & $\$$ Cask side \\
\hline 3 & -8.0 & $23-24-200211$ & \$ Cask side \\
\hline 3 & -8.0 & $24-25-200211$ & $\$$ Cask side \\
\hline 913 & $3-8.0$ & $\begin{array}{llll}25 & -26 & -200 & 211\end{array}$ & \$ Cask side \\
\hline
\end{tabular}

c

c Finally define cells for the air outside cask and the universe.

$\mathrm{c}$

$80 \uparrow-0.00122220-257-10 \$ 1 \mathrm{~cm}$ Air above cask - tally cell

$801 \quad 1-0.00122258-259-10 \leqslant 1 \mathrm{~m}$ Air above cask - tally cell

$802 \quad 1-0.00122260-261-10 \quad \$ 2 \mathrm{~m}$ Air above cask - tally cell

$8031-0.00122-1000220 \# 80 \# 801 \# 802$ \$ Rest of Air outside cask - top

$81 \quad 1-0.00122-100026-27 \quad 255-254 \$ 1 \mathrm{~cm}$ Air side - tally cell

$8111-0.00122-100028-29255-254 \$ 1 \mathrm{~m}$ Air side - tally cell

$8121-0.00122-100030-31255-254 \$ 2 \mathrm{~m}$ Air side - tally cell

$813 \uparrow-0.00122-100026251-220$ \#81 \#811 \#812 \$ Rest of Air - side

$821-0.00122-1000-251 \quad$ \$ Air outside cask - bottom

$8301000 \quad$ \$ Void-outside universe

c

c

1$$
2
$$

$15 \mathrm{cz} 35.7$ \$ Intermediate radius of Cask-biasing 


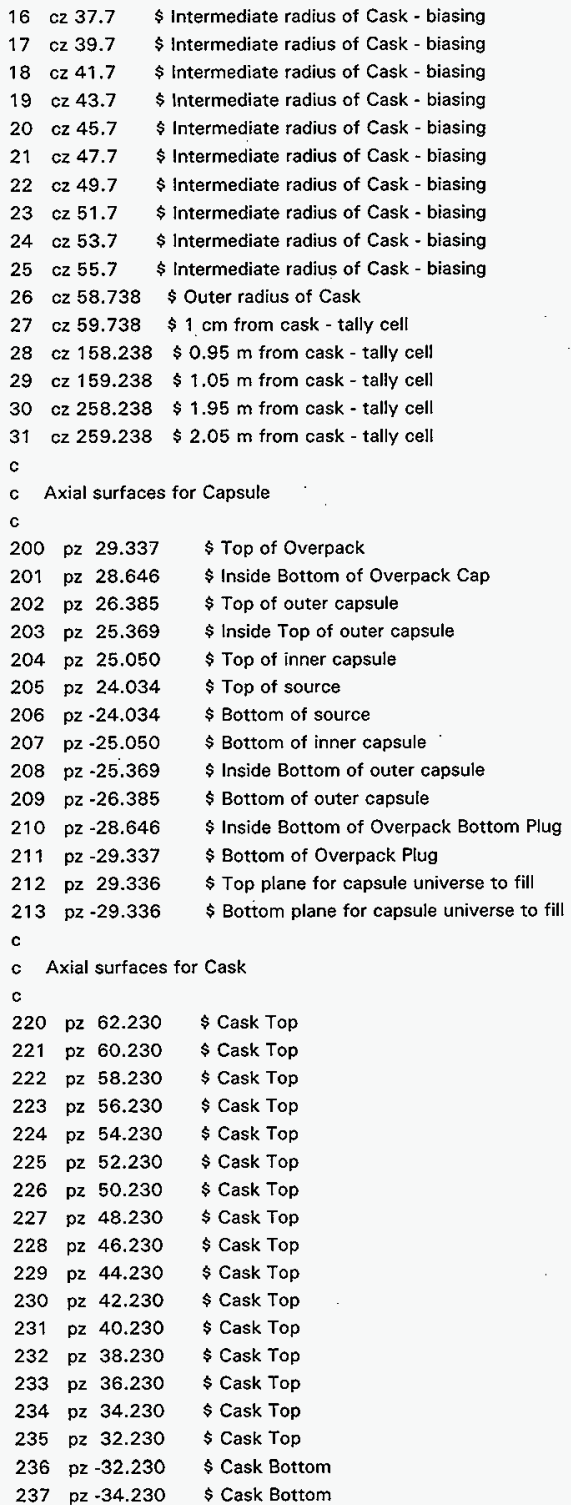




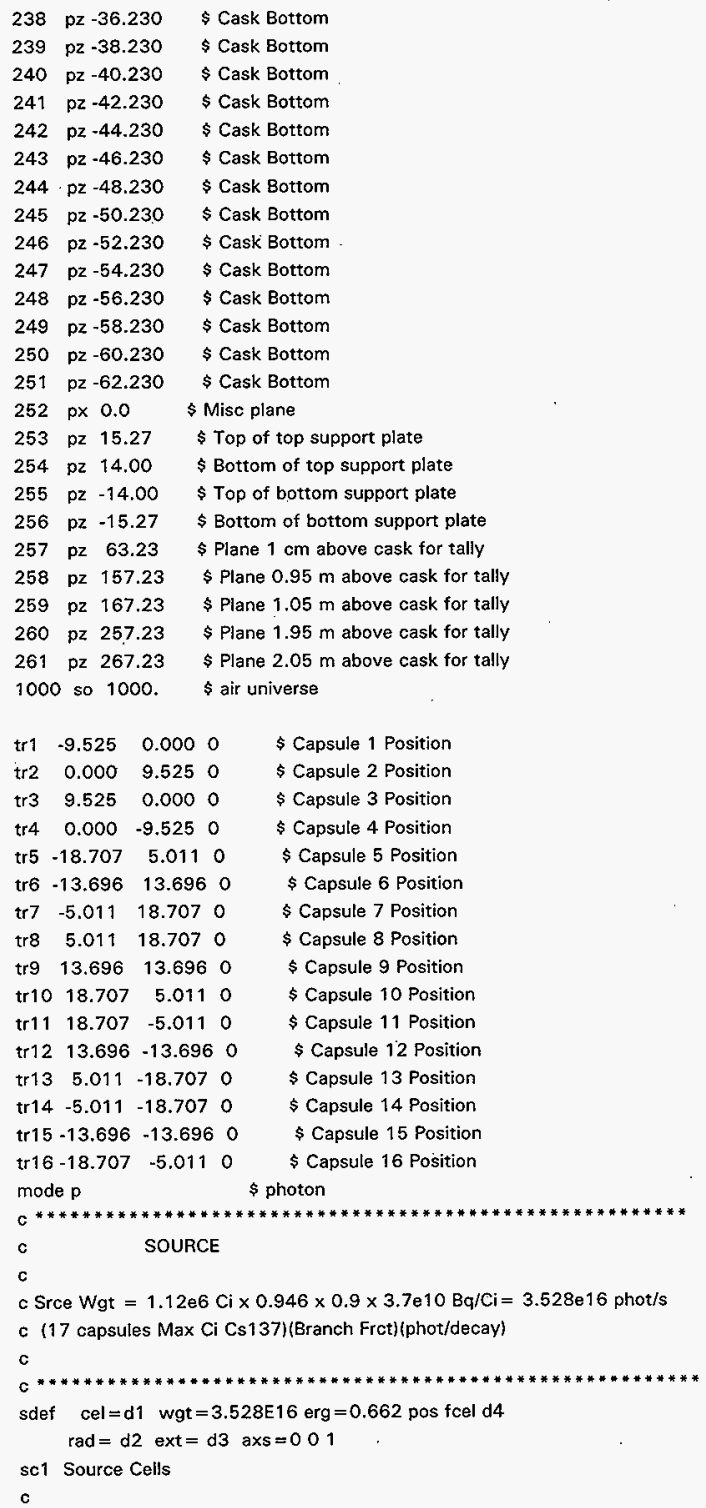




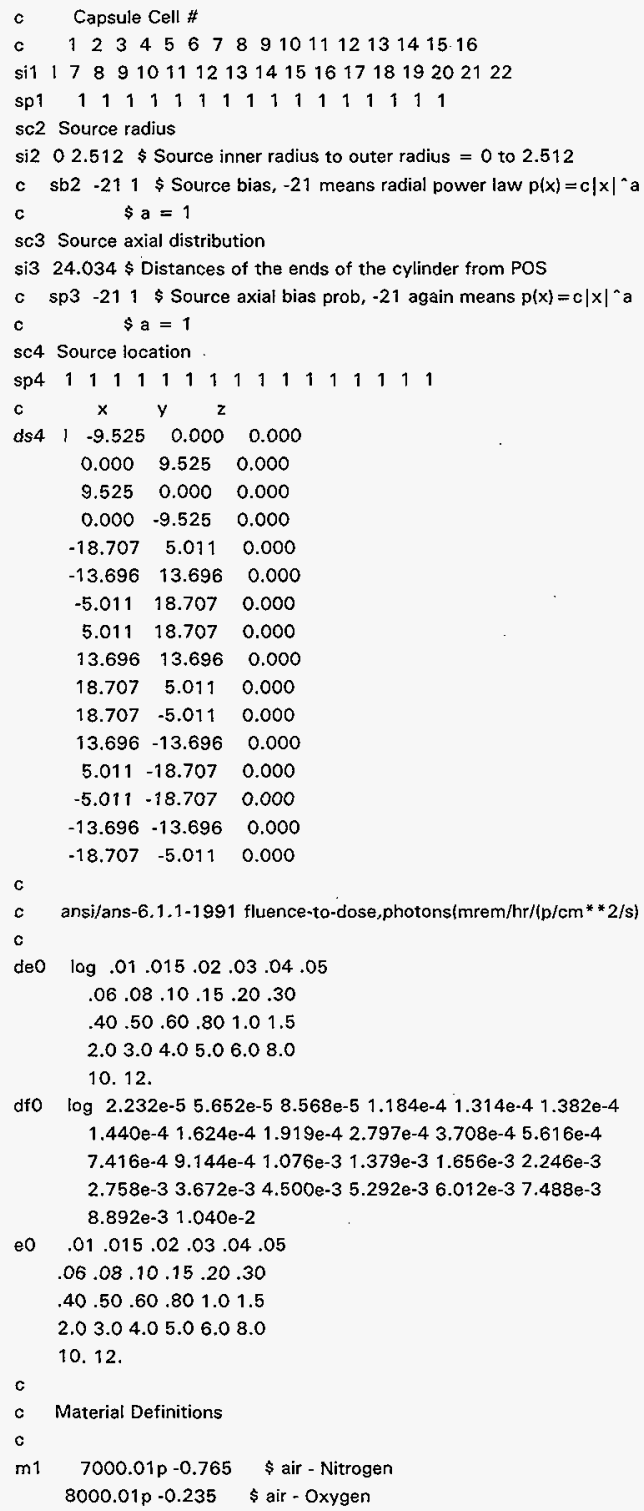




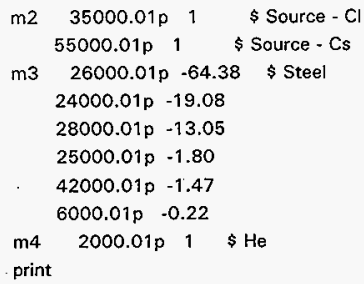




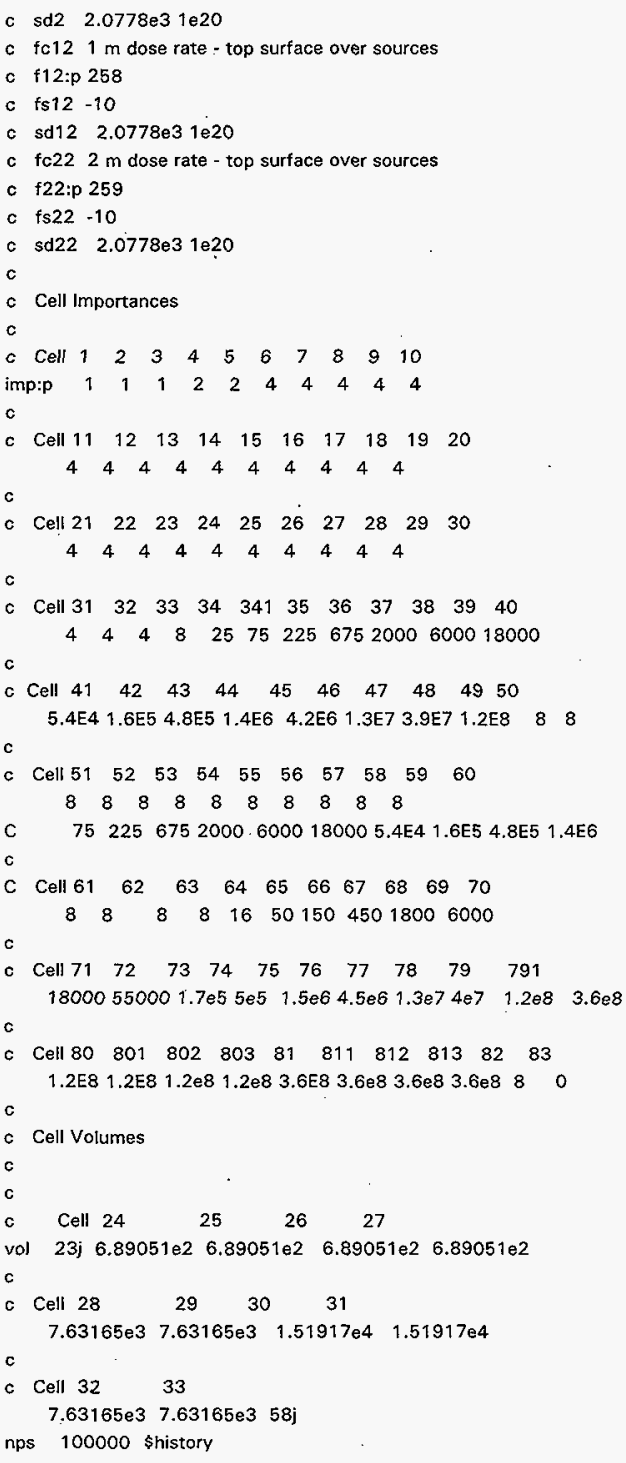




\subsubsection{MCNP Input File for Energy Deposition Model}

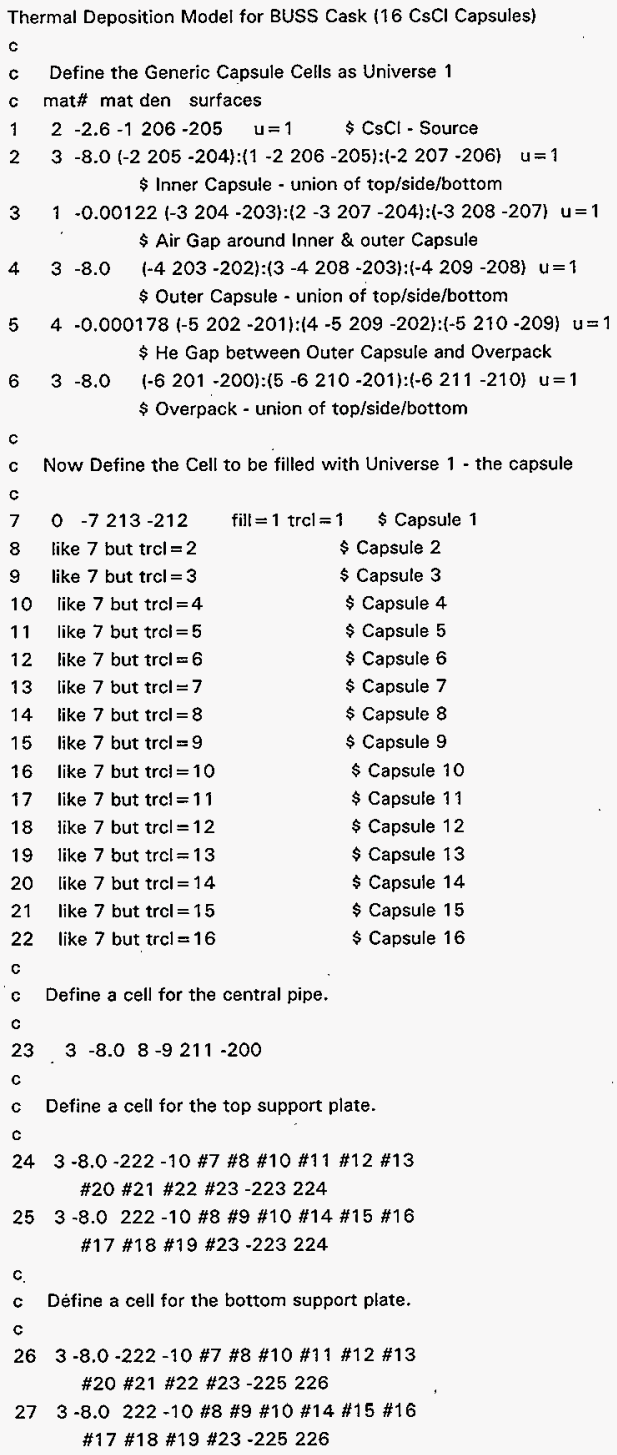


0.00122 -222 -10 \#7 \#8 \#10 \#11 \#12 \#13

$\# 20$ \#21 \#22 \#23 $225-224$

$\$$ Air around overpacks - Between top/bottom plates

$31 \quad 1-0.00122222-10 \# 8 \# 9 \# 10$ \#14 \#15 \#16 \#17 \#18\#19 \#23 $225-224$

$\$$ Air around overpacks - Between top/bottom plates

$321-0.00122-222-10$ \#7 \#8 \#10 \#11 \#12 \#13

\$20 \#21 \#22 \#23 $211-226$ \& Air around overpacks-Below bottom plate

$331-0.00122222-10 \# 8 \# 9$ \#10 \#14 \#15 \#16

\#17\#18 \#19 \#23 211 -226 \& Air around overpacks-Below bottom plate

c

c Now define cells for the cask.

c

$343-8.0-11200-220 \quad$ \$ Cask top

$353-8.010-11-200211$ \$ Cask side

$363-8.0-11221-211 \quad$ \$ Cask bottom

c

c Finally define cells for the air outside cask and the universe.

$371-0.00122(-1000220):(-100011221-220):(-1000-221)$

$\$$ Air outside cask - union of top/side/bottom

38

01000

$\$$ Void - outside universe

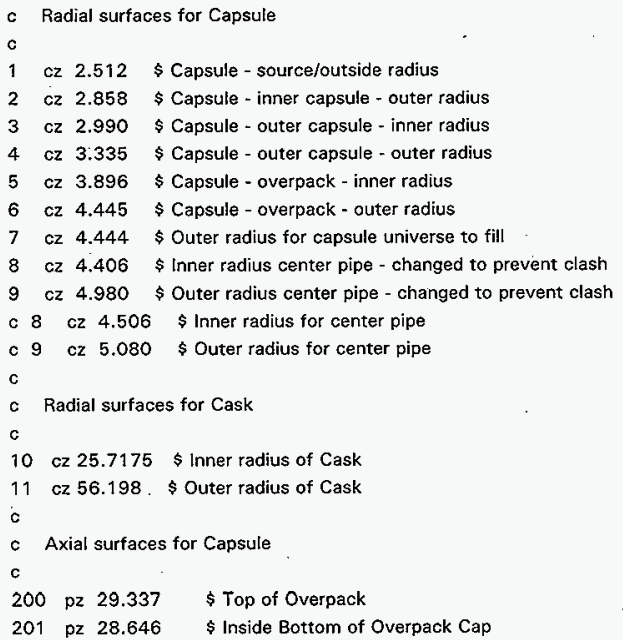



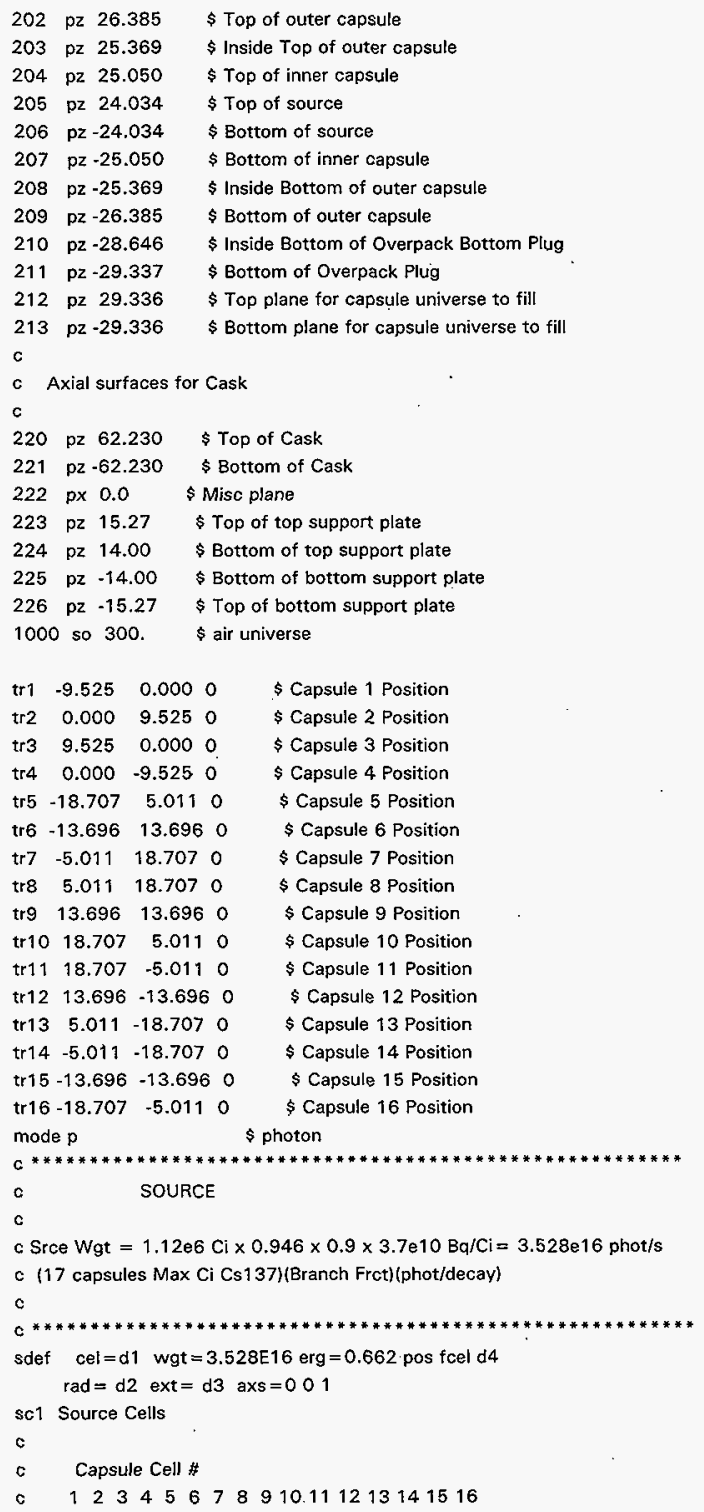


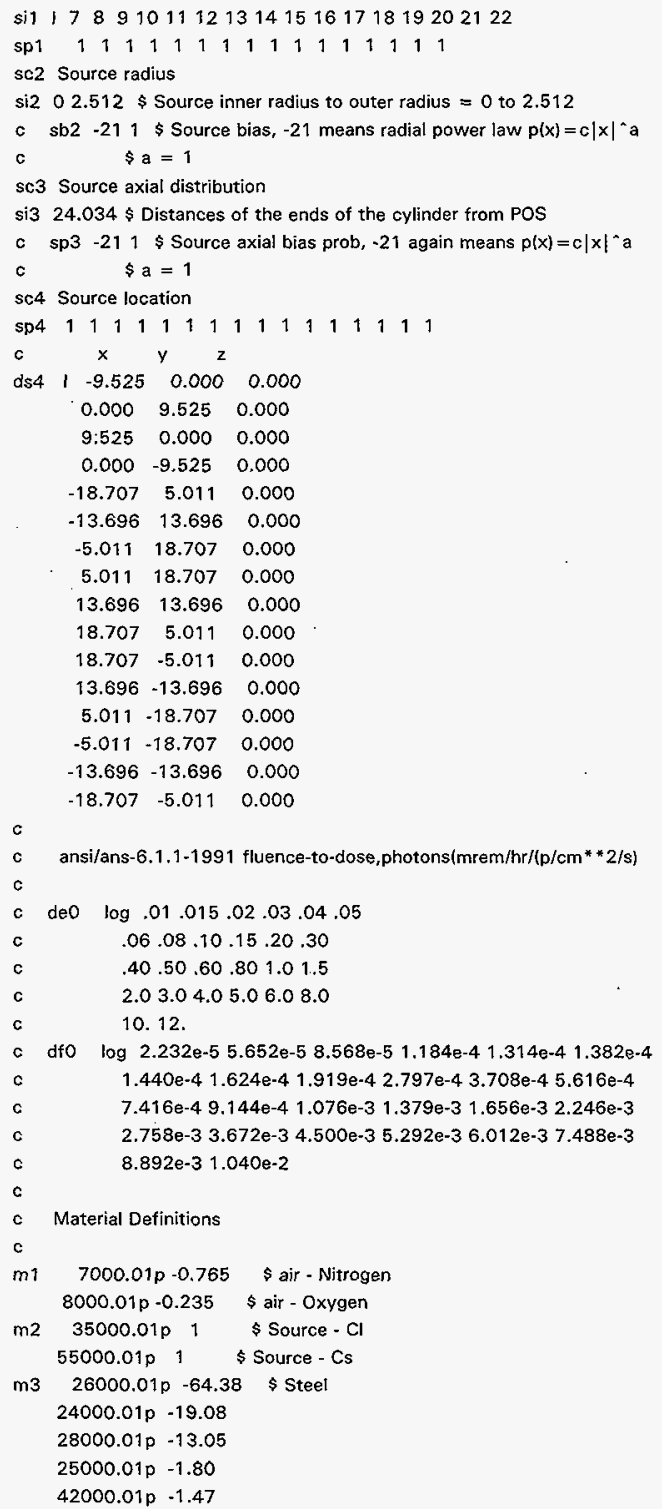




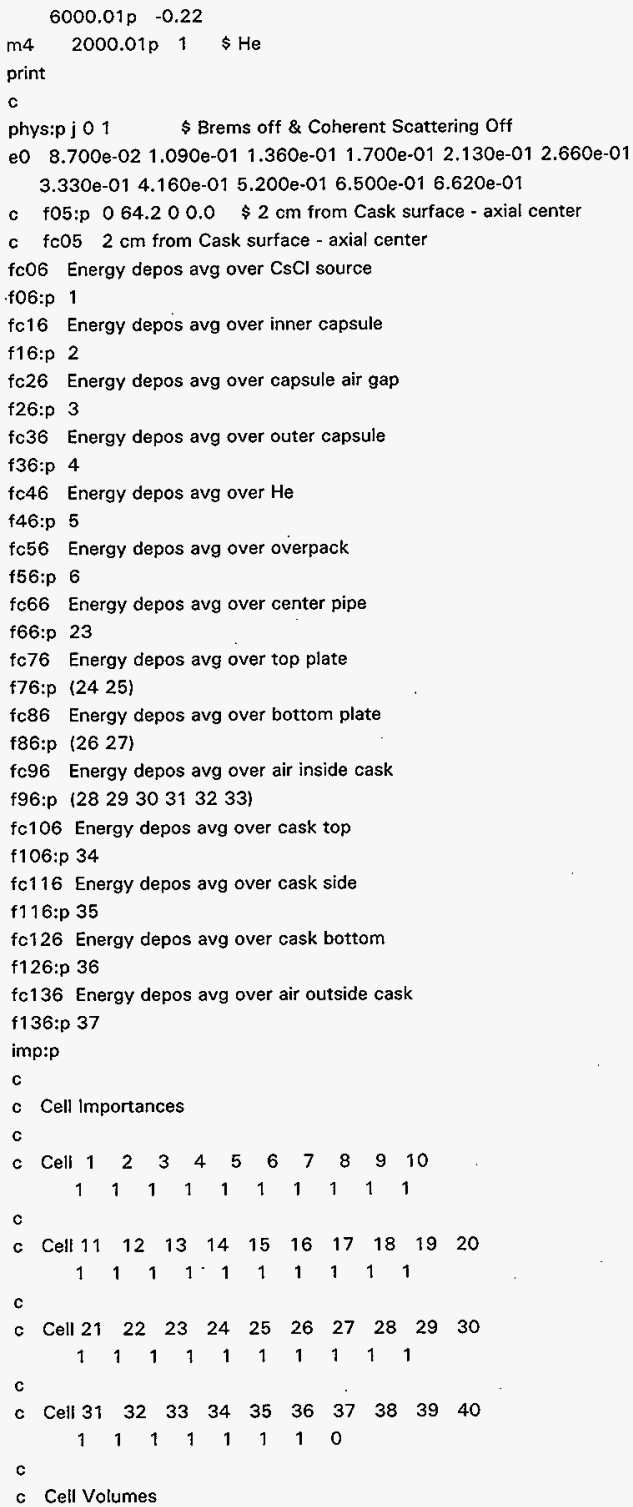

c Cell Volumes 
HNF-SD-TP-SEP-065 Rev. 0

$\mathrm{c}$

c

c Cell $24 \quad 25 \quad 26 \quad 27$

vol $23 \mathrm{j} \quad 6.89051 \mathrm{e} 2 \quad 6.89051 \mathrm{e} 2 \quad 6.89051 \mathrm{e} 2 \quad 6.89051 \mathrm{e} 2$

c

c Cell $28 \quad 29 \quad 30 \quad 31$

$7.63165 \mathrm{e} 3 \quad 7.63165 \mathrm{e} 3 \quad 1.51917 \mathrm{e} 4 \quad 1.51917 \mathrm{e} 4$

c

c Cell $32 \quad 33$

$7.63165 \mathrm{e} 37.63165 \mathrm{e} 35 \mathrm{j}$

nps 50000 \$history 


\subsubsection{Checklist for Peer Review}

\section{CHECKLIST FOR PEER REVIEH}

Document Reviewed: Shielding and Energy Deposition Analys is for the BUSS Cask SEP

Scope of Review: Entire shielding and energy deposition analysis Section 5.0

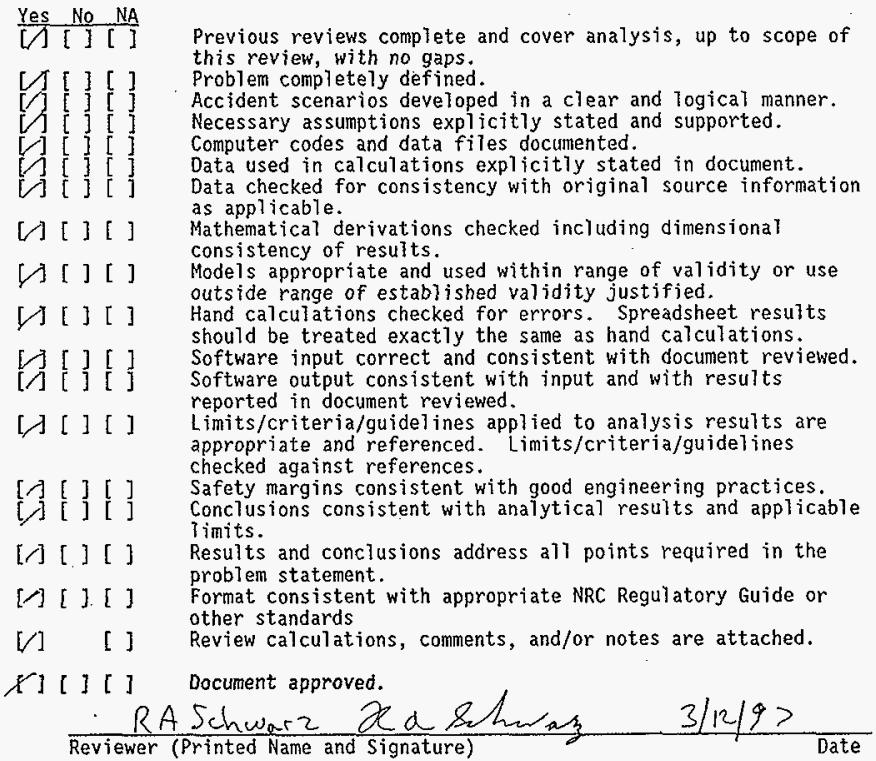


HNF-SD-TP-SEP-065 ReV. 0

\subsection{CRITICALITY EVALUATION}

No fissile materials are being transported so no criticality analysis is required. 
HNF-SD-TP-SEP-065 ReV. 0

This page intentionally left blank.

B6-2 


\subsection{STRUCTURAL EVALUATION}

\subsection{INTRODUCTION}

The BUSS Cask is currently licensed (DOE 1996) to carry 16 special form cesium chloride capsules based on an analysis in the SARP (SNL 1994). The structural differences between this shipment and the SARP configuration (SNL 1994) are the slightly smaller combined weight of the overpacked capsules in the new basket. In the shipment covered by this SEP, the cask weight will be less than the weight of the SARP configuration, so the cask will experience lower forces during the various accident scenarios. The thermal analysis (Part B, Section 8.0 ) shows that temperatures and temperature differences in this shipment are lower than those of the SARP configuration, so thermal stresses are bounded by the SARP analysis. Since the structural loading is bounded by those considered in the SARP, no analysis of the cask is necessary for this SEP. The cask will maintain confinement during all normal and accident conditions of transportation.

The Type W overpacked capsules are tested to the requirements for special form certification. Since the cask limits the peak acceleration of the cask body to $105 \mathrm{gs}$, which is an order of magnitude lower than that experienced by the overpack during its test, no structural analysis of the contents is required. The overpacked capsules will maintain containment during all normal and accident conditions of transportation.

\subsection{WEIGHT OF BASKET AND CONTENTS}

The BUSS Cask SARP (SNL 1994) evaluated the cask with a total package weight of $14,923 \mathrm{~kg}(32,900 \mathrm{lb})$. The estimated package weight for this shipment will be $576 \mathrm{~kg}(1,270 \mathrm{lb})$ less than this. The package weight for the shipment covered by this SEP will be $14,347 \mathrm{~kg}$ $(31,630 \mathrm{lb})$.

The SARP estimated the basket to weigh $726 \mathrm{~kg}(1,600 \mathrm{lb})$ and the 16 capsules to weigh $136 \mathrm{~kg}(300 \mathrm{lb})$; combined, the basket and contents weigh $862 \mathrm{~kg}(1,900 \mathrm{lb})$ in the SARP analysis. The table below shows that the combined contents weight for this shipment is $287 \mathrm{~kg}(632 \mathrm{lb})$, or $576 \mathrm{~kg}(1,270 \mathrm{lb})$ less than the SARP used in its evaluation.

\begin{tabular}{|c|c|c|}
\hline Components & $\begin{array}{c}\text { Stainless steel } \\
\text { (unit weight }=0.289 \mathrm{lb} / \mathrm{in}^{3} \text { ) }\end{array}$ & Weight (lb) \\
\hline \multicolumn{3}{|l|}{ Basket } \\
\hline Bottom plate & $1 / 2$ in., 20 in. diameter & 45.4 \\
\hline Upper plates (2) & 1 in., 20 in. diameter & 181.6 \\
\hline $\begin{array}{l}\text { Deduction for holes in upper } \\
\text { plates }\end{array}$ & $\begin{array}{l}32 \text { holes, } 3.5 \text { in. diameter } \\
2 \text { holes, } 4 \text { in. diameter }\end{array}$ & $\begin{array}{r}89.0 \\
3.6 \\
-92.6\end{array}$ \\
\hline Support pipe & $\begin{array}{l}3.5 \mathrm{in.} \mathrm{schedule} 40 \text { pipe, area }= \\
2.68 \mathrm{in}^{2}, 22.88 \mathrm{in} . \text { long }\end{array}$ & 17.2 \\
\hline Basket total & & 151.6 \\
\hline \multicolumn{2}{|l|}{ Overpacked Capsules (16) } & 480 \\
\hline Total Contents & & 632 \\
\hline
\end{tabular}


HNF-SD-TP-SEP-065 Rev. 0

\subsection{REFERENCES}

DOE, 1996, U.S. Department of Energy Certificate of Compliance for Radioactive Materials Packages, USA/9511/B(U) (DOE), Rev. 3, U.S. Department of Energy, Germantown, Maryland.

SNL, 1994, Beneficial Uses Shipping System (BUSS) Cask Safety Analysis Report for Packaging (SARP), Volumes I and II, SAND83-0698 (TCC-0430), Rev. 5, Sandia National Laboratories, Albuquerque, New Mexico. 


\subsection{THERMAL EVALUATION}

\subsection{INTRODUCTION}

The heat generation rate for the capsules in this shipment is significantly less than that assumed in the SARP (SNL 1994), but there are two significant configuration changes that cause the need for a thermal analysis. For this shipment, heat is conducted to the cask wall through helium rather than a solid stainless steel basket, and there is an additional gap in the heat path due to the new Type $W$ overpack. A thermal analysis is needed to demonstrate that the temperatures within the capsules and the cask are acceptable. The ANSYS finite element program was used for this purpose; its input is attached as Part B, Section 8.8.5 and the results summarized in Part B, Section 8.5.1. It demonstrates that temperatures during normal and accident conditions are within their limits, and that the SARP thermal stress analysis bounds the stresses for this shipment.

The thermal analysis in Part B, Section 8.8 .5 is based on the SARP analysis, and is not completely independent of it. The SARP's configuration was analyzed using ANSYS and checked to ensure that the answers were similar to the SARP's results, then the finite element model was modified to the configuration of this shipment. This procedure acts as a test of the modeling methods and data. It is necessary due to differences in the analysis programs and the SARP having omitted data.

After modeling the SARP configurations, four new configurations were modeled to determine the best basket design. The configuration selected was the simplest and least costly of the four and met the temperature requirements for normal and accident conditions of transportation.

After selecting the basket design, the analytical model was run with more conservative parameters and an updated basket design to determine the maximum temperatures. Case 1 a of Table B8-8 presents these results: all temperatures are less than their limits, except the cesium chloride maximum temperature is at its arbitrary limit. Additional cases were run with modified parameters to test their effects, and these results are shown in Table B8-8.

\subsection{THERMAL SOURCE SPECIFICATION}

Table B8-1 gives the temperature limits and the calculated NCT temperatures used as limits for this SEP.

The temperature limits in this SEP are the limits used for the SARP. However, since the SARP did not limit the maximum cesium chloride temperature at the center of a capsule, this SEP uses the maximum calculated cesium chloride temperature $\left[462^{\circ} \mathrm{C}\left[864^{\circ} \mathrm{F}\right]\right.$ as a limit. This temperature has been reviewed and accepted for shipments in the BUSS Cask based on serviceability limits; higher temperatures were acceptable for safety considerations, but the capsule could then not be used in a commercial facility. 
Table B8-1. SARP Results and Allowable Temperatures.

\begin{tabular}{|l|l|l|l|}
\hline \multicolumn{1}{|c|}{ Location } & \multicolumn{1}{|c|}{$\begin{array}{c}\text { Calculated temperature, } \\
16 \text { capsules } \\
{ }^{\circ} \mathrm{C}\left({ }^{\circ} \mathrm{F}\right)\end{array}$} & $\begin{array}{c}\text { Calculated temperature, } \\
12 \text { capsules } \\
{ }^{\circ} \mathrm{C}\left({ }^{\circ} \mathrm{F}\right)\end{array}$ & \multicolumn{1}{|c|}{$\begin{array}{c}\text { SARP allowable } \\
\text { temperature } \\
{ }^{\circ} \mathrm{C}\left({ }^{\circ} \mathrm{F}\right)\end{array}$} \\
\hline Cesium chloride & $438(820)$ & $462(864)$ & ${\mathrm{N} / \mathrm{A}^{1}}^{1}$ \\
\hline Inner cladding & $398(748)$ & $407(765)$ & $450(842)^{2}$ \\
\hline Outer cladding & $371(700)$ & $369(696)$ & $800(1472)^{3}$ \\
\hline Basket & $356(673)$ & $348(658)$ & $800(1472)$ \\
\hline Lid or port seals & $202(396)$ & $202(396)$ & $450(842)^{4}$ \\
\hline Inner cask wall seal limit & $202(396)$ & $202(396)$ & $800(1472)$ \\
\hline Outer cask wall & $140(284)$ & $140(284)$ & $800(1472)^{5}$ \\
\hline
\end{tabular}

DOT $=$ U.S. Department of Transportation

SARP = Safety Analysis Reporn for Packaging.

${ }^{\prime}$ Cesium chloride melts at $646^{\circ} \mathrm{C}\left(1195^{\circ} \mathrm{F}\right)$, and it undergoes a phase change between $350-470^{\circ} \mathrm{C}$ $\left(662-878^{\circ} \mathrm{F}\right)$. (SNL 1984).

${ }^{2}$ The inner cladding temperature limit was based on testing for long-term geologic disposal. Below $450^{\circ} \mathrm{C}\left(842^{\circ} \mathrm{F}\right)$, there is no anticipated corrosion of the cladding material in contact with cesium chloride.

${ }^{3}$ The stainless steel temperature limits other than the inner cladding was based on reducing the potential for significant corrosion. The capsules were initially tested at a temperature of $800^{\circ} \mathrm{C}\left(1472{ }^{\circ} \mathrm{F}\right)$ without loss of contents.

${ }^{4}$ Seal temperature limits are the maximum operating temperatures (SARP) provided by the manufacturer. (Helicoflex copper-lined inner seal with a section diameter of $0.58 \mathrm{~cm}$. Helicoflex defines this temperature as the point the seal no longer resists pressure.) The SARP shows that the seal temperatures are less than the cask inner wall temperatures; this analysis did not model the seal areas since the inner wall temperature was less than the long-term seal limit in all cases.

${ }^{5}$ The outer wall temperature is significantly higher than the DOT limit of $85^{\circ} \mathrm{C}\left(185^{\circ} \mathrm{F}\right)$; a protective barrier is provided around the cask for personal protection.

SNL, 1984, WESF ${ }^{137}$ Cs Gamma Ray Sources, SAND82-1492, Sandia National Laboratories, Albuquerque, New Mexico.

Helicoflex is a trademark of the Helicoflex Corporation.

\subsection{THERMAL PROPERTIES OF MATERIALS}

\subsubsection{T304 Stainless Steel Properties}

$$
\begin{aligned}
\text { Density } & =7900 \mathrm{~kg} / \mathrm{m}^{3} \text { (White 1991) } \\
& =493 \mathrm{lbf} / \mathrm{ft}^{3} \\
& =0.285 \mathrm{lbf} / \mathrm{in}^{3}
\end{aligned}
$$

Heat capacity $c_{p}=477 \mathrm{~J} / \mathrm{kg} \cdot{ }^{\circ} \mathrm{K}=0.114 \mathrm{Btu} / \mathrm{lb} \cdot \mathrm{F}$ (White 1991) 
Thermal conductivity, $K$ (ASME 1992) is given in Table B8-2.

Table B8-2. Stainless Steel Thermal Conductivity.

\begin{tabular}{|l|l|l|l|l|l|l|l|l|}
\hline${ }^{\circ} \mathrm{F}$ & 70 & 100 & 150 & 200 & 250 & 300 & 350 & 400 \\
\hline $\mathrm{K}, \mathrm{BTU} / \mathrm{h} / \mathrm{ft} /{ }^{\circ} \mathrm{F}$ & 8.6 & 8.7 & 9 & 9.3 & 9.6 & 9.8 & 10 & 10.4 \\
\hline $\mathrm{K}, \mathrm{BTU} / \mathrm{h} / \mathrm{in} /{ }^{\circ} \mathrm{F}$ & 0.72 & 0.73 & 0.75 & 0.78 & 0.80 & 0.80 & 0.80 & 0.87 \\
\hline${ }^{\circ} \mathrm{F}$ & 450 & 500 & 550 & 600 & 650 & 700 & 750 & 800 \\
\hline $\mathrm{K}, \mathrm{BTU} / \mathrm{h} / \mathrm{ft} /{ }^{\circ} \mathrm{F}$ & 11 & 10.9 & 11 & 11 & 11.6 & 12 & 12 & 12.2 \\
\hline $\mathrm{K}, \mathrm{BTU} / \mathrm{h} / \mathrm{in} /{ }^{\circ} \mathrm{F}$ & 0.90 & 0.91 & 0.93 & 0.94 & 0.97 & 0.98 & 1.00 & 1.02 \\
\hline
\end{tabular}

\subsubsection{Helium Properties .(White 1991)}

Density $=0.1627 \mathrm{Kg} / \mathrm{m} 3$ at $300^{\circ} \mathrm{K}=5.88 \mathrm{lb} \cdot 10^{-6} / \mathrm{in} 3$ at $80^{\circ} \mathrm{F}$

Heat capacity $=5197 \mathrm{~J} / \mathrm{kg} \cdot{ }^{\circ} \mathrm{K}=1.24 \mathrm{Btu} / \mathrm{hr} / \mathrm{bb} \cdot{ }^{\circ} \mathrm{F}$

Conductivity and unit conversion is given in Table B8-3.

Table B8-3. Helium Conductivity, K.

\begin{tabular}{|l|r|r|r|r|r|r|r|r|}
\hline$T^{\circ} \mathrm{K}$ & 300 & 350 & 400 & 450 & 500 & 550 & 600 & 700 \\
\hline $\mathrm{K} \mathrm{W} / \mathrm{m}-\mathrm{K}$ & 0.150 & 0.165 & 0.180 & 0.195 & 0.211 & 0.229 & 0.247 & 0.278 \\
\hline $\mathrm{T}^{\circ} \mathrm{F}$ & 81 & 171 & 261 & 351 & 441 & 531 & 621 & 801 \\
\hline $\mathrm{K}, \mathrm{Btu} / \mathrm{h} / \mathrm{in} / \mathrm{F}$ & 0.0072 & 0.0079 & 0.0087 & 0.0094 & 0.0102 & 0.0110 & 0.0119 & 0.0134 \\
\hline
\end{tabular}

\subsubsection{Properties of Cesium Chloride}

The following properties were used in this analysis due to their use in the SARP (SNL 1994). The SARP stated that there was a wide range in conductivity values in the literature, and that the SARP used the minimum value, which will maximize the cesium chloride temperature.

$$
\begin{aligned}
& \text { Density }=0.0939 \mathrm{lbf} / \mathrm{in}^{3} \text { ( Sp.G. of } 2.6 \text { ) } \\
& \text { Heat capacity, } C_{p}=8400 \mathrm{~J} / \mathrm{kg}^{*} \mathrm{~K} \\
& \text { Thermal conductivity }=0.45 \mathrm{~W} / \mathrm{m}^{*} \mathrm{~K}
\end{aligned}
$$


8.3.3.1 Heat Generation. Part A, Section 3.0 shows that the average heat generation for all 16 overpacked capsules is $191 \mathrm{~W}$ per capsule. However, since the finite element model considered only a $45^{\circ}$ segment of the cask due to symmetry, an average must be found for each octant.

Part $B$, Section 8.8 .3 shows with the most favorable capsule arrangement, the highest average in one octant is $193.4 \mathrm{~W}$ and this analysis uses $195 \mathrm{~W}$ for a margin. The capsule arrangement within the package must be controlled using the sketch shown in Part A, Section 6.0.

8.3.3.2 Heat Distribution. Heat generation is caused by absorption of radiation by the package's materials and occurs throughout the package, including the cesium chloride salt. The BUSS Cask SARP's shielding analysis (SNL 1994) calculated a thermal energy distribution that was used in the SARP thermal analysis, but this distribution is not valid for this package due to the third encapsulation layer (the Type $W$ overpack) and the new basket design. The shielding analysis in Part B, Section 5.0 of this SEP calculated a heat distribution which is compared to the SARP results in Table B8-4. The SEP analysis found a heat deposition in the cesium chloride that is much less than was found in the SARP, and a higher deposition in the encapsulation. The higher percentage of thermal power in the encapsulation is explained by the increased thickness of encapsulation in this package compared to the SARP, but this is overstated because the SEP shielding analysis uses a Type $S$ overpack $(5 \mathrm{~mm}$ [0.21 in.] thick) rather than the Type $W$ overpack ( $3 \mathrm{~mm}[0.13 \mathrm{in.}$ ) actually being used. For conservatism, the SARP heat deposition to the cesium chloride, $50 \%$ of the thermal power, was used in this analysis. Since the heating of the encapsulation is linearly dependent on the thickness, and the overpack adds a third layer as thick as each of the two inner layers of steel, the total heat absorption in the encapsulation should be 1.5 times the SARP's value. The SARP used $13 \%$ distribution in the encapsulation, so this SEP uses $20 \%$. The remainder of the capsule's thermal energy, $30 \%$, is deposited in the BUSS Cask walls.

Table B8-4. Heat Distribution within the BUSS Cask.

\begin{tabular}{|l|l|l|l|}
\hline \multicolumn{1}{|c|}{ Package component } & $\begin{array}{c}\text { SARP shielding } \\
\text { analysis } \\
\% \text { power }\end{array}$ & $\begin{array}{c}\text { SEP shielding } \\
\text { analysis } \\
\% \text { power }\end{array}$ & $\begin{array}{c}\text { SEP thermal } \\
\text { analysis } \\
\% \text { power }\end{array}$ \\
\hline Cesium chloride & 50 & 37 & 50 \\
\hline Steel capsule (and overpack) & 13 & 24 & 20 \\
\hline Basket & 30 & & \\
\hline Cask wall & 7 & 21 & 30 \\
\hline Central support & & 2 & \\
\hline Other basket components & & 15 & \\
\hline
\end{tabular}

SARP $=$ Safety Analysis Report for Packaging.

SEP $=$ Safety Evaluation for Packaging.

\subsubsection{Properties of Air and the Convection Rate at the Cask Surface}

- The SARP used a convection film factor of $5 \mathrm{~W} / \mathrm{m}^{2 *} \mathrm{~K}$ on the surface of the horizontal cylinder without stating the assumed temperature range it was valid for. This SEP uses a variable coefficient that is calculated in Part B, Section 8.8.2. At the surface temperature calculated by the $\operatorname{SEP}\left(141^{\circ} \mathrm{C}\right)$, the film coefficient is 5.38 . The lower temperature resulting from the higher 
convection is balanced by the SEP's using an environmental temperature $8^{\circ} \mathrm{C}\left(15^{\circ} \mathrm{F}\right)$ higher than the SARP. The SARP multiplies the convection rate by 4.7 and the radiation heat transfer rate by 1.5 to account for the $10 \mathrm{~cm}(4 \mathrm{in}$.) deep fins on the cask surface. Both of these factors were formulated in the SARP, but the calculated numbers were not shown; they are caiculated in Part B, Section 8.8.1.

Table B8-5. Thermal Properties of Air. (White 1991)

\begin{tabular}{|r|r|r|r|}
\hline $\begin{array}{c}\text { Temp } \\
{ }^{\circ} \mathrm{K}\end{array}$ & $\begin{array}{c}\mathrm{K} \\
W / \mathrm{m}^{*} \mathrm{~K}\end{array}$ & $\mathrm{Pr}$ & $\mathrm{g} \beta / \mathrm{N}^{2}=\mathrm{Gr} /\left(\mathrm{D}^{3} \cdot \Delta \mathrm{T}\right)$ \\
\hline 200 & $1.81 \mathrm{E}-02$ & 0.740 & $8.57 \mathrm{E}+08$ \\
\hline 250 & $2.23 \mathrm{E}-02$ & 0.724 & $3.02 \mathrm{E}+08$ \\
\hline 300 & $2.61 \mathrm{E}-02$ & 0.712 & $1.33 \mathrm{E}+08$ \\
\hline 350 & $2.97 \mathrm{E}-02$ & 0.706 & $6.60 \mathrm{E}+07$ \\
\hline 400 & $3.31 \mathrm{E}-02$ & 0.703 & $3.63 \mathrm{E}+07$ \\
\hline 450 & $3.63 \mathrm{E}-02$ & 0.700 & $2.16 \mathrm{E}+07$ \\
\hline 500 & $3.95 \mathrm{E}-02$ & 0.699 & $1.36 \mathrm{E}+07$ \\
\hline
\end{tabular}

density $=1.177 \mathrm{~kg} / \mathrm{m}^{3}$ at $27^{\circ} \mathrm{C}$

$\mathrm{C}_{\mathrm{p}}=1005 \mathrm{~J} / \mathrm{kg}^{\circ} \mathrm{C}$ at $27^{\circ} \mathrm{C}$

\subsection{INITIAL CONDITIONS}

\subsubsection{Normal Conditions of Transportation}

The SARP used the (NCT) specified by 10 CFR 71.71, including still air, ambient temperature of $38^{\circ} \mathrm{C}\left(100^{\circ} \mathrm{F}\right.$ ) and $200 \mathrm{~g}-\mathrm{cal} / \mathrm{cm}^{2}$ (over 12 hours) insolation. This SEP uses the Hanford maximum of $46^{\circ} \mathrm{C}\left(115^{\circ} \mathrm{F}\right)$ ambient temperature and an insolation of $50 \mathrm{BTU} / \mathrm{h} / \mathrm{ft}^{2}$ (Irwin 1996). This insolation value is less than that used in the SARP:

$1 B T U=251.98 \mathrm{~g}$-cal, so $50 \mathrm{Btu} / \mathrm{hrff} \mathrm{f}^{2}=151,200 \mathrm{~g}$-cal/ft ${ }^{2}$ over 12 hours

and since $1 \mathrm{ft}^{2}=929 \mathrm{~cm}^{2}$, the insolation is $\frac{151,200}{929}=163 \mathrm{~g}$-cal/12 hours

\subsubsection{Hypothetical Accident Conditions}

The SARP analyzed the BUSS Cask with 12 or 16 cesium chloride capsules under HAC that included a $30 \mathrm{ft}$ drop, puncture, and a 30 minute fire with a temperature of $800{ }^{\circ} \mathrm{C}$, a surface emissivity of 0.8 and environmental emissivity of 0.9 . Under these conditions, and using the temperature distribution resulting from the NCT model, the SARP reported no temperature rise in the capsules during the 30 minute fire. The maximum temperature rise in the capsules was $25^{\circ} \mathrm{C}$ $\left(45^{\circ} \mathrm{F}\right)$ for the 12 capsule case and $14^{\circ} \mathrm{C}\left(25^{\circ} \mathrm{F}\right)$ for the 16 capsule case hours later. The SARP's temperature limit for the capsules is $800^{\circ} \mathrm{C}\left(1472^{\circ} \mathrm{F}\right)$, and the maximum initial temperature of a 
capsule is $462{ }^{\circ} \mathrm{C}\left(864^{\circ} \mathrm{F}\right)$ in this shipment. The SARP's temperature limit for accident conditions will not be approached in this shipment since it will experience about the same temperature rise as the SARP case, and no thermal analysis is necessary.

\subsection{THERMAL ANALYSES}

A finite element thermal analysis was done in three stages:

1. Model the SARP's shipping configuration to confirm some thermal properties and test the modeling method. Three key pieces of information were missing from the SARP, and had to be calculated in this analysis: the heat transfer film coefficient, the fin efficiency factor, and heat source length. The film coefficient and fin factors are calculated in Part B, Section 8.8.1. The length of the heat source within the capsule is needed to find the heat generation per unit area, and this was not provided in the SARP. The minimum length, and the highest two-dimensional heat generation, can be found from the following: The inside height is $48.0 \mathrm{~cm}$ (18.9 in.) and the cesium chloride underwent a $17 \%$ volume reduction (SNL 1984) after the capsule was filled. Since the diameter of the salt had to remain the same, the length of the salt column reduced by $17 \%$ to $39.8 \mathrm{~cm}$ (15.7 in.). Any subsequent volumetric change will lead to a lower heat generation density, so using this length will produce conservative results. The SARP configuration model found that the SARP results could be approximated with a two-dimensional model if the heat-generating length of the capsules was 16 in. The ANSYS input file is provided in Part B, Section 8.8.4 and the results are shown in Table B8-6.

2. Various basket designs were studied to find the simplest one that provided acceptable temperatures. Four configurations, one shown in Figure B8-1, with temperatures in Table B8-7. While the configurations with fins reduced the temperatures, the simplest basket (Case 1) resulted in acceptable temperatures and the least cost.

3. A final model was produced form the results of step 2 by raising the capsule's power level from $191 \mathrm{~W}$ to $195 \mathrm{~W}$, lowering the stainless steel emissivity from 0.5 to a more conservative value of 0.3 , and moving the capsule's position within the cask. These results are Case $1 \mathrm{a}$ in Table B8-8, and demonstrate that the normal condition temperatures of the cask and contents will remain at or below the temperatures calculated in the SARP. The effect of lowering the emissivity alone was about an $11^{\circ} \mathrm{C}\left(20^{\circ} \mathrm{F}\right)$ temperature rise in the cesium chloride.

4. Additional runs were made with changed parameters: increased power levels, more realistic heat distribution within the package, reduced fin effectiveness, and reduced conduction within the cask. The results of this study, shown in Table B8-8, show that the model is most sensitive to the capsule power.

\subsubsection{Model of the Original Configuration}

The ANSYS solid modeling processor was used to model a $45^{\circ}$ segment of the basket and cask wall. This is a two-dimensional model using ANSYS PLANE55, 4-node elements for conduction areas, LINK31 2-node elements for radiation links between capsule layers, and SURF19 surface effect elements for convection and radiation to an atmosphere node outside of the cask. Internal gaps are assumed to be concentric, conservatively neglecting surface-to-surface contacts. 
The model included one complete capsule and two half capsules of $250 \mathrm{~W}$ thermal power per capsule. The total power in the segment was divided by $41 \mathrm{~cm}(16 \mathrm{in}$.$) to find the power per$ unit length, and divided by the cross-section area to find the heat generation per unit area. The resulting heat generation density is distributed through the various regions of the model using the SARP assumptions $150 \%$ in the cesium chloride and the remainder in the capsule layers, basket, and cask walls.

The cask fins convection rate was $5 \mathrm{~W} / \mathrm{m}^{2} \cdot{ }^{\circ} \mathrm{C}$ (per SARP) multiplied by a fin convection factor of 4.7, as calculated in Part B, Section 8.8.1. The SARP's environmental temperature $\left(100^{\circ} \mathrm{F}\right)$ and the emissivity (0.5) were used. The input and output files are in Part $\mathrm{B}$, Section 8.8.4, and the results are summarized below. There was close enough agreement between the ANSYS model and the SARP results to use the model as a starting point for the overpacked capsule analysis, and have confidence in the results.

Table B8-6. Results of the SARP Model; Temp, ${ }^{\circ} \mathrm{F}$.

\begin{tabular}{|l|l|l|l|}
\hline \multicolumn{1}{|c|}{ Location } & \multicolumn{1}{c|}{ SARP } & \multicolumn{1}{c|}{ tmax } & \multicolumn{1}{c|}{ tmin } \\
\hline Cesium chloride & 820 & 834 & 680 \\
\hline Inner capsule & 748 & 738 & 679 \\
\hline Outer capsule & 699 & 684 & 598 \\
\hline Basket & 673 & 659 & 536 \\
\hline Cask inner surface & 396 & 403 & 401 \\
\hline Cask outer surface & 284 & 285 & 285 \\
\hline
\end{tabular}

\subsubsection{Modeling 16 Overpacked Capsules}

The model used for the first analysis was changed to account for the open basket and the overpack. The basket's horizontal plates are neglected and heat is conducted through the helium using the properties given above. The only feature of the basket in the model is the central support pipe, which was modeled as a solid element to account for the radiation from it to the cask wall. In reality, the $3 \mathrm{~cm}(1 \mathrm{in}$.) thick plates will conduct a significant amount of heat and lessen the temperature difference between the hottest and coldest capsules. All gaps were modeled as concentric, and no convection inside the cask was modeled, which adds to the conservatism.

The following results were obtained by running four basket configurations to select the best one. The contents are 16 overpacked capsules with a power level of $191 \mathrm{~W}$, and are compared to the SARP 16-250 $\mathrm{W}$ capsule case. The conclusion is that in all cases, the cesium chloride temperatures are less than those reported in the SARP; so additional heat paths are not necessary and Case 1 is the best basket design. 
Table B8-7. Temperature Results, ${ }^{\circ} \mathrm{F}$.

\begin{tabular}{|l|l|l|l|l|c|c|c|c|c|}
\hline \multirow{2}{*}{ Location } & \multirow{2}{*}{$\begin{array}{c}\text { SARP } \\
\text { file b0 }\end{array}$} & \multicolumn{2}{|c|}{$\begin{array}{c}\text { Case 1 file: } \\
\text { b16 }\end{array}$} & \multicolumn{2}{c|}{$\begin{array}{c}\text { Case 2 } \\
\text { file: b16r }\end{array}$} & \multicolumn{2}{c|}{$\begin{array}{c}\text { Case 3 } \\
\text { file: b16t }\end{array}$} & \multicolumn{2}{c|}{$\begin{array}{c}\text { Case 4 } \\
\text { file: b16z }\end{array}$} \\
\cline { 2 - 11 } & & $\max$ & $\min$ & $\max$ & $\min$ & $\max$ & $\min$ & $\max$ & $\min$ \\
\hline Cesium chloride & 820 & 803 & 614 & 775 & 583 & 777 & 597 & 737 & 591 \\
\hline Inner capsule & 748 & 731 & 614 & 701 & 582 & 705 & 597 & 670 & 591 \\
\hline Outer capsule & 699 & 693 & 542 & 651 & 512 & 666 & 525 & 624 & 526 \\
\hline Overpack & $\ldots$ & 674 & 480 & 632 & 452 & 646 & 459 & & \\
\hline Support pipe & 673 & 648 & 646 & 609 & 586 & 637 & 469 & 592 & 417 \\
\hline Cask inner surface & 396 & 317 & 311 & 297 & 291 & 312 & 305 & 311 & 305 \\
\hline Cask outer surface & 284 & 238 & 237 & 220 & 220 & 227 & 226 & 227 & 226 \\
\hline
\end{tabular}

SARP = Safety Analysis Report for Packaging.

'Basket temperature for SARP.

Figure B8-1. Preliminary Models.

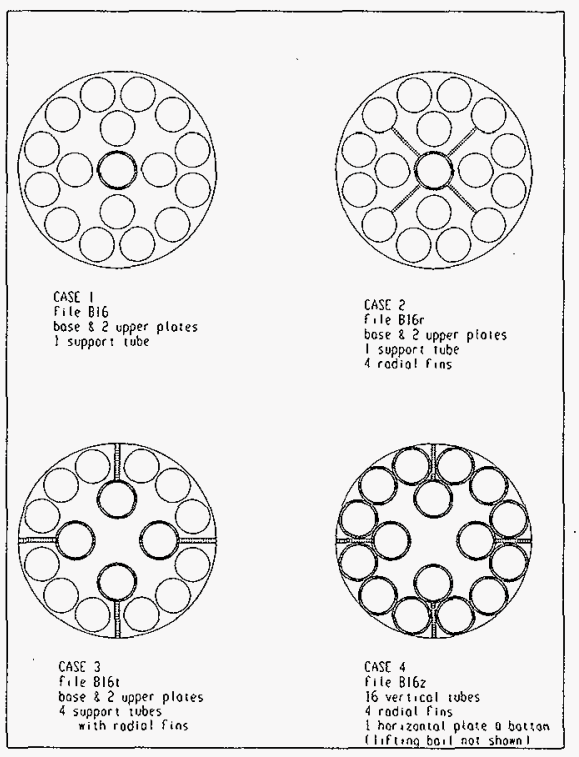

Case 1: Bottom plate, two upper plates with holes for the capsules, and a central support pipe.

Case 2: Central tube with four small fins, three horizontal plates.

Case 3: Four support tubes with fins, three horizontal plates.

Case 4: Sixteen vertical tubes, one horizontal plate. 
The following results are variations of Case 1 , the selected design. Case $1 \mathrm{a}$ is the analysis on which this evaluation rests. It differs from Case 1, above, by using a variable convection rate, higher capsule power, lower emissivity for the stainless steel, and a different heat generation distribution.

Case 1a: Base case. Fin factor (model parameter $F n)=4.7$ multiplies the convection rate; fin efficiency factor (parameter $=F_{\text {eff }}$ ) $=1.5$; overpack thickness (thk 3 ) $=$ 0.13 ; Power $(W)=195$; Capsules located as close to the cask walls as possible $(\operatorname{Rad} 5=4.25$, $\operatorname{Rad} 6=7.88)$; conservative power distribution $(50 \%$ power in cesium chloride, $20 \%$ power in capsule layers). Stainless steel emissivity $=0.3$.

Case 1b: Reduced the heat deposition within the cesium chioride and increase the encapsulation heating to match this SEP's shielding analysis $137 \%$ power in cesium chloride, $24 \%$ in the capsule layers). This reduces the cesium chloride maximum temperature by $40^{\circ} \mathrm{C}\left(72^{\circ} \mathrm{F}\right)$, and is more realistic than Case $1 \mathrm{a}$.

Case 1c: Cut the fin convection factor in half $(F n=2.35)$ and use a fin efficiency factor of 1.0 . This produced a cesium chloride temperature $19^{\circ} \mathrm{C}\left(35^{\circ} \mathrm{F}\right)$ higher than Case $1 \mathrm{a}$ and would result if the fin factors were grossly overstated. Their formulation was reviewed in the SARP; however, so using them in this analysis is not unconservative.

Case 1d: Increase capsule power $(W)$ to $215 \mathrm{~W}$, the average of the three highest power capsules. This produced cesium chloride temperatures $26^{\circ} \mathrm{C}\left(47^{\circ} \mathrm{F}\right)$ higher than Case 1a. It demonstrates the necessity of controlling the position of the capsules within the cask.

Case 1e: Replace the He conductivity in the cask with air conductivity, simulating SARP accident conditions, in which He is assumed to leak out. The cesium chloride temperature rises $18^{\circ} \mathrm{C}\left(32^{\circ} \mathrm{F}\right)$ over the base case.

Table B8-8. Maximum Temperatures in Base Case and Variations.

\begin{tabular}{|l|l|l|l|l|l|l|l|}
\cline { 2 - 8 } \multicolumn{1}{c|}{} & Case 1a & Case 1b & Case 1c & Case 1d & Case 1e & \multicolumn{1}{|c|}{ Limit } & $\begin{array}{c}\text { SARP } \\
\text { (max) }\end{array}$ \\
\hline Cesium chloride & 864 & 792 & 899 & 911 & 896 & 864 & 864 \\
\hline Inner cladding & 790 & 738 & 825 & 829 & 822 & 842 & 765 \\
\hline Outer cladding & 741 & 698 & 779 & 778 & 776 & 1472 & 700 \\
\hline Overpack & 718 & 679 & 756 & 754 & 754 & 1472 & \\
\hline Support pipe & 692 & 658 & 731 & 726 & 719 & 1472 & 673 \\
\hline Cask inner surface & 338 & 332 & 418 & 356 & 338 & $\begin{array}{l}842 \\
\text { (for seals) }\end{array}$ & 396 \\
\hline Cask outer surface & 253 & 254 & 337 & 264 & 253 & 284 & 284 \\
\hline
\end{tabular}


These variations show that the model is behaving reasonably, and is not unduly sensitive to any one parameter. The model is most sensitive to the thermal power of the capsules and the heat deposition within the package. The power is well known, but the distribution is not well defined so a conservative heat deposition is used for this analysis. This conservatism, and the fact that the two-dimensional model neglects heat loss through the capsules ends and conduction through the two plates of the basket assure that the results are conservative. Even if improbable errors produced the results of Cases $1 c, 1 d$, or 1e, no thermal limits of the SARP would be exceeded.

The primary check of a finite element model is to reduce the element size and rerun it to see if the temperatures at key locations converge. This was easily done since element size was a model parameter. In the final run, the element sizes were halved and the cesium chloride temperatures rose only $1^{\circ} \mathrm{C}$. Another check is to note that the equilibrium temperatures of the outer cask surface varies only when the power level is increased or the surface heat transfer parameters are changed. A third check is to verify that all of the input energy is accounted for. This was done by summing the energy input:

$$
\begin{aligned}
& \text { Capsule heat generation }=\frac{195 \mathrm{~W}}{16} \times 2 \text { caps/segment }=24.38 \mathrm{~W} \\
& 24.38 \times 3.412 \frac{B t u / h}{W}=83.2 \text { Btu/h } \\
& \text { Insolation }=\frac{50 \text { Btulh/ft }}{144}=.347 \text { Btu/h/in }{ }^{2} \text { on a } 52 \text { in. diam cylinder with } \varepsilon=.3 \\
& .3 \times .347 \times 52=5.4 \text { Btulh on the entire upper half cylinder, or } 2.1 \text { on } 45^{\circ} \text { segment }
\end{aligned}
$$$$
83.2+2.1=85.3
$$

and comparing this to the nodal "reaction" at the environment node. Over $98 \%$ of the input energy is accounted for.

As a last check, the base model (file B16a) was run with the number of elements inside of the cask walls doubled. A plot of the thermal energy error was checked for both runs: it showed that the energy error is fairly uniform for all of the various materials, with a local maximum error in the Helium, between the cask wall and the lower capsule. In doubling the number of elements, this maximum error dropped from 0.36 to 0.09 , and the temperatures inside of the cask were raised by $1{ }^{\circ} \mathrm{C}$. The size of the error is not significant, but the fact that it is uniform, with a local maximum in an area that is not thermally significant, and the small temperature change for a halving of the element size indicates that the model is working correctly.

ANSYS geometry plots are provided at the end of this chapter to aid in reviewing the results of the analysis.

\subsection{CONCLUSIONS}

Under normal conditions of transportation, the calculated cask walis and the cesium chloride temperatures are less than the SARP allowables. The inner cladding is about the same temperature as the SARP maximum, and the overpack wall is only $18^{\circ} \mathrm{F}$ higher than the SARP-predicted outer cladding temperature. The temperature difference between the inner and outer walls is $338-253$ 
$=85^{\circ} \mathrm{F}$, which is less than the SARP's $396-284=112^{\circ} \mathrm{F}$, so the thermal stresses will be bounded by the SARP's predictions and a new structural analysis is not required.

Under HAC, this shipment will behave similar to the SARP's conclusions since the cask and overpacks are unchanged. Part B, Section 8.3.2 of the SARP notes that, starting from the NCT, the $800^{\circ} \mathrm{C}\left(1470^{\circ} \mathrm{F}\right)$ fire temperature will cause $15^{\circ} \mathrm{C}\left(25^{\circ} \mathrm{F}\right)$ rise in the maximum cesium chloride temperature for the 16 capsule case, resulting in a temperature of $889^{\circ} \mathrm{F}$. Even if an accident causes a loss of helium in the cask, thermal analysis Case 1e shows that the maximum cesium chloride temperature will be $18^{\circ} \mathrm{F}$ higher than the SARP's maximum NCT temperature.

Figure B8-2. B16a Plots. (4 sheets total)

B16a, plot 1

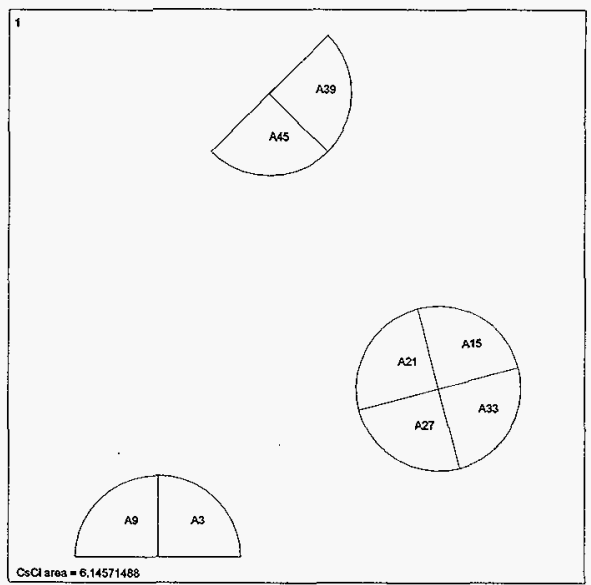




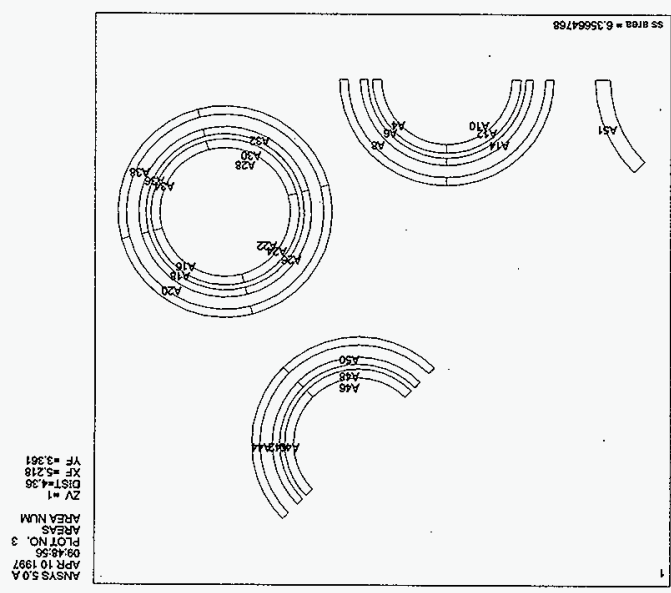

$\varepsilon$ 잉 'e9เ8

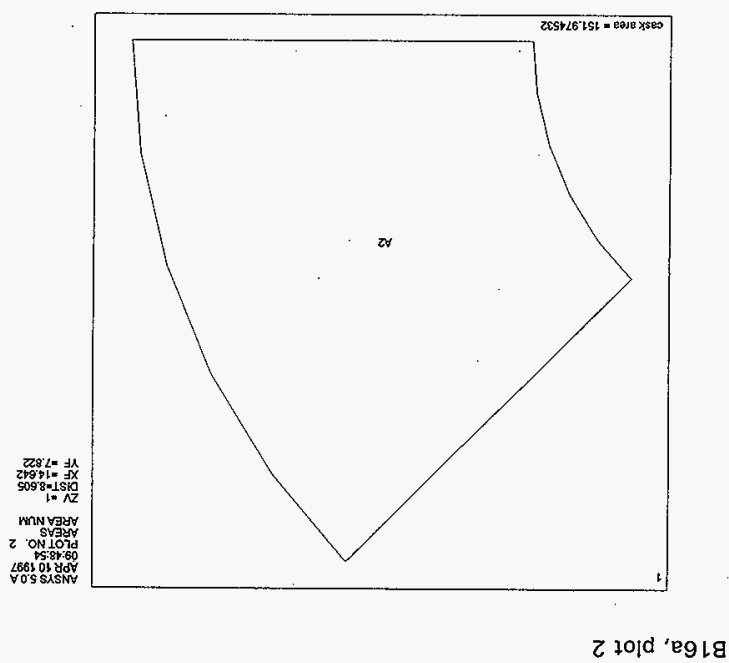

(ןezol słəəus t) 'siold eglg 'Z-8g әגn6! 
HNF-SD-TP-SEP-065 ReV. 0

Figure B8-2. B16a Plots. (4 sheets total)

B16a, plot 4
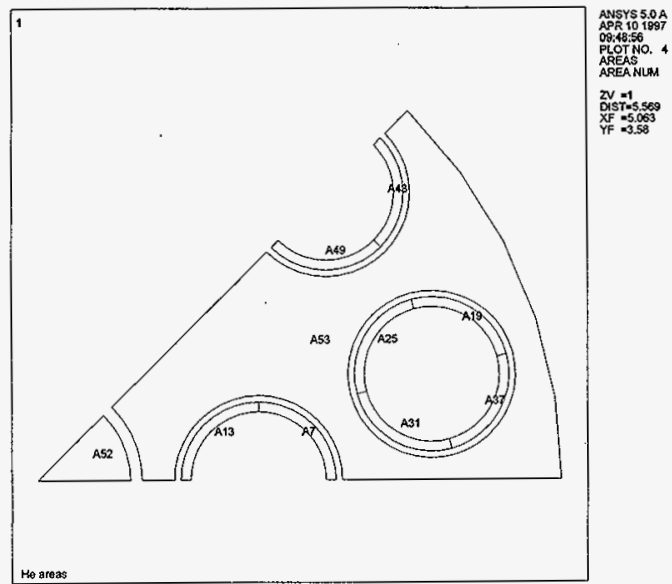

B16a, plot5

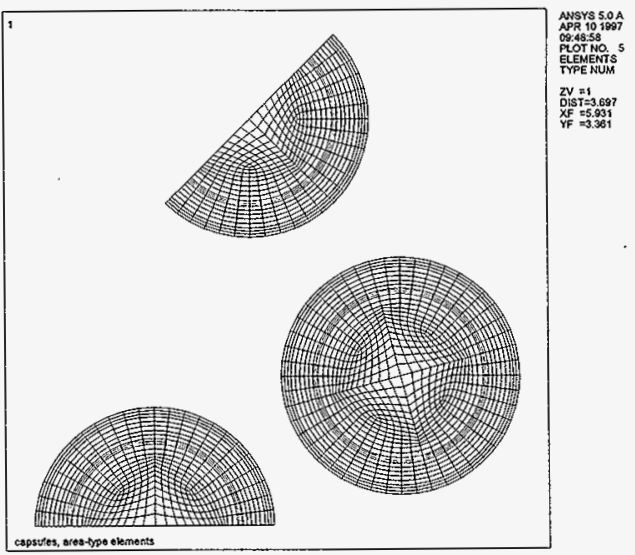


HNF-SD-TP-SEP-065 Rev. 0

Figure B8-2. B16a Piots. (4 sheets total)

B16a, plot 6

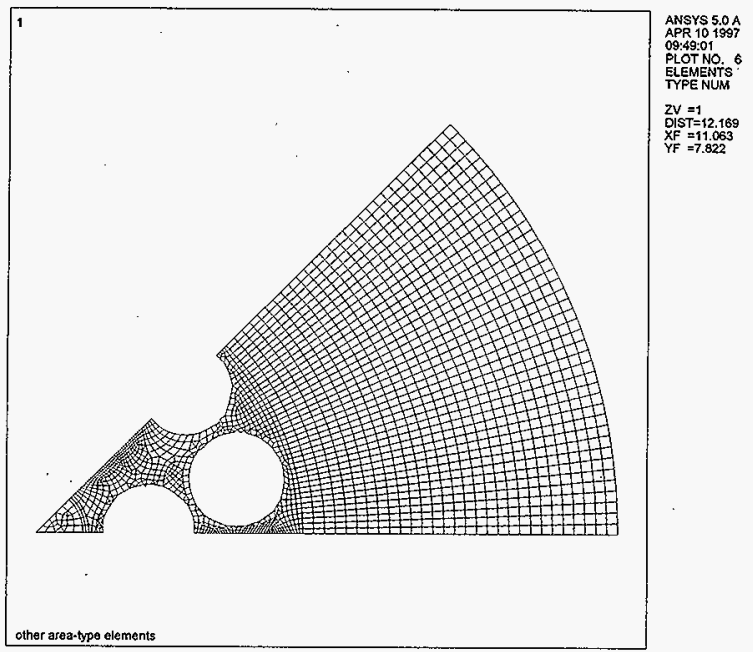

B16a, plot 7

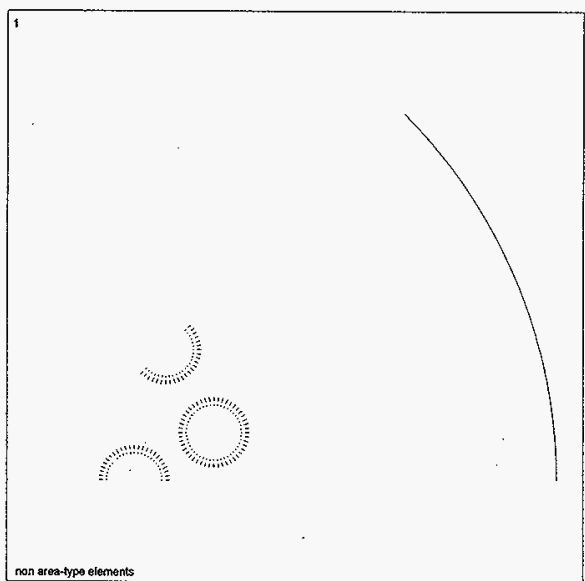

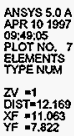




\section{HNF-SD-TP-SEP-065 Rev. 0}

\subsection{REFERENCES}

10 CFR 71, 1994, "Packaging and Transportation of Radioactive Material," Code of Federal Regulations, as amended.

ANSYS, Version 5.2, copyright by SAS IP, 1995, as an unpublished work.

ASME, 1992, Boiler and Pressure Vessel Code, Section II, Part D, American Society of Mechanical Engineers, New York, New York.

Irwin J. J., 1996, Thermal Analysis Methods for Safety Analysis Reports For Packaging, WHC-SD-TP-RPT-005, Rev. 1, Westinghouse Hanford Company, Richland, Washington.

SNL, 1994, Beneficial Uses Shipping System (BUSS) Cask Safety Analysis Report for Packaging (SARP), Volumes I and II, SAND83-0698 (TCC-0430), Rev. 5, Sandia National Laboratories, Albuquerque, New Mexico.

SNL, 1984, WESF ${ }^{137}$ CS Gamma Ray Sources, SAND82-1492, Sandia National Laboratories, Albuquerque, New Mexico.

White F. M., 1991, Heat and Mass Transfer, Addison-Wesley Publishing Company, New York, New York. 


\subsection{APPENDICES}

\subsubsection{Convection and Radiation Calculations}

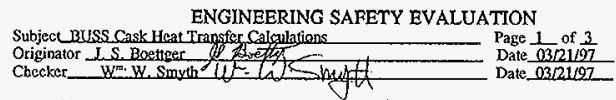

I. Objectivesi

It is desired to find equivalent heat transfer cocfficients for the BUSS cask so that it may be modelled as a cylinder. The actual BUSS cask has 11 equally sraced fins. The approach used will be to find the tatio of heat transfer coefficients, $h_{1}$ for the finned case and $h_{2}$ for the unfinned case, which produce equal heat transfer rates. Also, a comparison of radiation heat transfer rates is made to determine an equivalent radiation heat transfer rate for the unfinned case.

II. Refecences:

SNL, 1994, Beneficial Usas Shipping System Cask (BUSS), Safety Analysis Report for Packaging (SARP). Rev. 5, Sandia National Laboratories, Alburquerque, New Mexico.

III. Results and.Conclusions:

A multiplier of 4.72 should be used for the convective heat transfer coefficient when modelling the cask without fins.

The radiation heat transfer rate is $50 \%$ more efficient for the finned, case, therefore a multiplicr of 1.5 should be used when modelling the cask without fins.

IV. Enginececing Evaluation:

Use the SARP (SNL, 1994) mothodology for all calculations:

Convection

With Fins

The convective heat transfer rate, $q_{c}$, is:

$\mathrm{q}_{\mathrm{o}}=\mathrm{q}_{\mathrm{f}}+\mathrm{q}_{\mathrm{o}}$

Where, $\quad g_{t}=$ heat transfer rate from finned surfaces

$q_{o}=$ heat transfer tate from unfinned surfaces

The heat transfer rate from the finned surfaces is:

$q_{s}=N \eta q_{\max }$

where, $\quad q_{\max }=$ heat transfer rate assuming entre fin is at base temperature and is defined as:

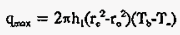

where, $\quad r_{0}=$ equivalent fin radius $=r_{t}+\sqrt{2},(27.375 \mathrm{in}$.

$r_{0}=$ radius at fin edge, $(27.125 \mathrm{in}$.)

$r_{\mathrm{n}} \quad=$ radius at fin base, $(23.125 \mathrm{in}$.)

$t \quad=$ fin thickness, $(0.5$ in.)

$T_{b} \quad=$ Temperature at base of fin

T. $=$ Temperature of the environment 


\section{ENGINEERING SAFETY EVALUATION}

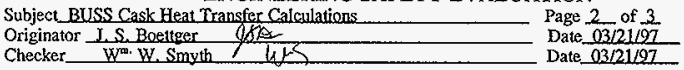

Thus, $\mathrm{q}_{\mathrm{F}}=2 \pi N \eta \mathrm{h}_{1}\left(\mathrm{r}_{\mathrm{o}}^{2}-\mathrm{r}_{0}^{2}\right)\left(\mathrm{T}_{\mathrm{b}}-\mathrm{T}_{-}\right)$

The heat transfer rate from the unfinned surfaces is:

$q_{a}=h A_{0}\left(T_{b}-T_{b}\right)$, where $A_{0}=2 \pi r_{b}(H-N t)$, and $H=20.5$ in.

$g_{c}=2 \pi h_{1}\left(T_{b}-T_{b}\right)\left\{N n\left(r_{c}^{2}-r_{0}^{2}\right)+r_{0}(H-N t)\right\}$

\section{Without fins}

The heat transfer rate without fins is:

$g_{w}=2 \pi r_{0} \operatorname{th}_{2}\left(T_{b}-T_{-}\right)$

Equating $\mathrm{q}_{w}$ and $\mathrm{q}_{\mathrm{c}}$ and solving for $\mathrm{h}_{2}$ gives:

$$
h_{2}=h_{1}\left\{\frac{N M\left(r_{c}^{2}-r_{0}^{2}\right)+r_{0}(H-N t)}{r_{0} H}\right\}
$$

$h_{2}=4.72 h_{1}$

Thus, when modelling the BUSS Cask as a cylinder, a multiplication factor of 4.72 should be used with the heat transfer coefficient.

Radiation

Comparing radiation heat transfer rate with fins to heat transfer rate without fins.

With Fins

With fins, the heat transfer rate is given as:

$\mathrm{q}_{\mathrm{R}}=\mathrm{q}_{\mathrm{coo}}+\mathrm{q}_{\text {lintip }}$

Gene = heat transfer rate from enclosed portion of fin

$\mathrm{q}_{\text {fontip }}=$ heat transfer rate from end of fin

$$
q_{\text {enc }}=\frac{\sigma\left(T_{b}^{4}-T_{-}^{4}\right)}{R_{1+*}}+\frac{\sigma\left(T_{b}^{4}-T_{*}^{4}\right)}{R_{2-\infty}}
$$


ENGINEERING SAFETY EVALUATION

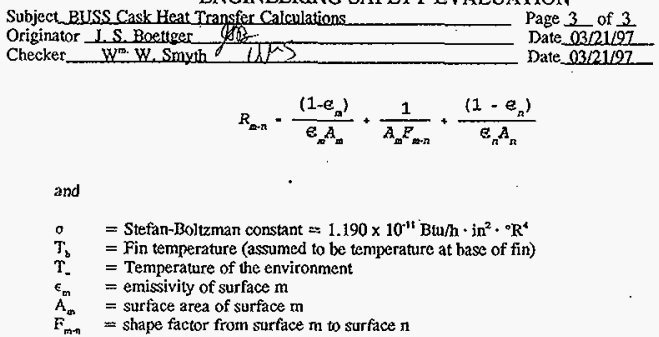

Surface 1 is the area between fins, and surface 2 is the surface area of the fin sides. Therefore,

$A_{1}=N\left(2 \pi r_{0} l\right) \quad=2400 i_{2}$, where $1=$ distance between fins $=1.5 \mathrm{in}$.

$A_{2}=2 \mathrm{~N} \pi\left(\pi_{c}^{2}-r_{0}^{2}\right)=13900 \mathrm{in}_{2}$

$F_{1-}=0.0894$, and

$\mathrm{F}_{2+}=0.1294$, as given in the BUSS SARP.

$\epsilon_{1}=\epsilon_{2}=0.5$

$R_{1--}=0.0051 \mathrm{in}^{-2}$

$R_{2-}=0.00063 \mathrm{in}^{-2}$

$q_{\text {exc }}=2.12 \times 10^{8}\left(T_{b}{ }^{4}-T_{-}^{4}\right)$

Grintip $_{p}=\operatorname{aeA}\left(\mathrm{T}_{4}^{4}-\mathrm{T}_{*}^{4}\right)$, where

$A=N\left(2 \pi r_{0} t\right)=937 \mathrm{in}^{2}$

$c=0.5$

$\mathrm{q}_{\mathrm{En} \cdot \mathrm{ip}}=5.60 \times 10^{4}\left(\mathrm{~T}_{\mathrm{b}}^{4}-\mathrm{T}_{\mathrm{A}}^{4}\right)$

$q_{R}=2.68 \times 10^{3}\left(T_{b}^{4}-T_{-}^{4}\right)$

Without Fins

$\mathrm{q}_{\mathrm{norio}}=\operatorname{oeA}\left(\mathrm{T}_{\mathrm{b}}{ }^{4}-\mathrm{T}_{-}^{4}\right)$, where

$\mathrm{A}=2 \pi \mathrm{r}_{0} \mathrm{H}=3000 \mathrm{in}^{2}$

$\epsilon=0.5$

$\mathrm{q}_{\mathrm{n} \times \mathrm{in}}=1.79 \times 10^{8}\left(\mathrm{~T}_{\mathrm{s}}^{4}-\mathrm{T}_{-}^{4}\right)$

The ratio $q_{R} / q_{n-1 \times n}=1.5$ 


\subsubsection{BUSS Cask Heat Transfer Calculations}

ENGINEERING EVALUATION

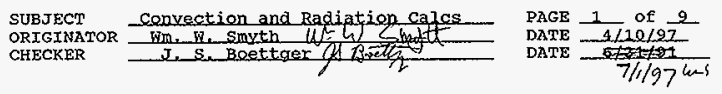

1. Objective: Find the convection film coefficient for a horizontal cylinder in air, with the air temperature between 100 and $120^{\circ} \mathrm{F}$.

II. References:

White: Heat and Mass Transfer, 1991, Frank M. White ASME: 1992

III. Results and conclusions:

The free convection rate for a $1.12 \mathrm{~m}\left(44^{\prime \prime}\right)$ horizontal cylinder, in air, using the properties and methods from white, are given in the following table. For comparison, the SARP's value of $5 \mathrm{H} / \mathrm{m}^{2}$. oK is equivalent to $6.1210^{-3} \mathrm{Btu} / \mathrm{hr} \cdot \mathrm{in}^{2}$ ${ }^{\circ} \mathrm{F}$ which requires a surface temperature of about $250^{\circ} \mathrm{F}$ in $117^{\circ} \mathrm{F}$ air.

\begin{tabular}{|c|c|c|c|c|c|c|}
\hline & \multicolumn{2}{|c|}{${ }_{T=0}=81\left(^{\circ} x\right)$} & \multicolumn{2}{|c|}{$\begin{array}{l}\text { air tente } \\
\mathrm{T}=99\left(\mathrm{C}^{\circ}\right)\end{array}$} & \multicolumn{2}{|c|}{$\begin{array}{l}\text { air temp } \\
T .\end{array}$} \\
\hline $\begin{array}{r}\text { surface } \\
\text { temp }\end{array}$ & $\Delta \mathrm{T}$ & h & $\Delta \mathrm{T}$ & $\mathrm{h}$ & $\Delta T$ & h \\
\hline $\mathrm{T}_{.}{ }^{\circ} \mathrm{F}$ & $\wedge^{\wedge} F$ & $\begin{array}{l}\text { BTU/hr } \\
\text { inn of }\end{array}$ & ${ }^{\circ} \mathrm{F}$ & $\sin ^{\mathrm{BT} / \mathrm{hr}}$ & ${ }^{\circ} \mathrm{F}$ & BTu/hr \\
\hline 100 & 19 & $3.674 e-03$ & 1 & $1.402 \mathrm{e}-03$ & & \\
\hline 120 & 39 & $4.613 e-03$ & 21 & $3.610 \mathrm{e}-03$ & 3 & I. $877 \mathrm{e}-03$ \\
\hline 140 & 59 & $5.263 \mathrm{e}-03$ & 41 & $4.462 \mathrm{e}-03$ & 23 & $3.545 \mathrm{e}-03$ \\
\hline 160 & 79 & $5.776 \mathrm{e}-03$ & 61 & $5.062 \mathrm{e}-03$ & 43 & $4.321 \mathrm{e}-03$ \\
\hline 180 & 99 & $6.208 \mathrm{e}-03$ & 81 & $5.541 \mathrm{e}-03$ & 63 & $4.878 e-03$ \\
\hline 200 & 119 & $6.585 \mathrm{e}-03$ & 101 & $5.945 \mathrm{e}-03$ & 83 & $5.325 e-03$ \\
\hline 220 & 139 & $6.921 \mathrm{e}-03$ & 121 & $6.299 \mathrm{e}-03$ & 103 & $5.705 e-03$ \\
\hline 240 & 159 & $7.225 \mathrm{e}-03$ & 141 & $6.615 \mathrm{e}-03$ & 123 & $6.038 \mathrm{e}-03$ \\
\hline 260 & 179 & $7.505 \mathrm{e}-03$ & 161 & $6.902 \mathrm{e}-03$ & 143 & 6. $336 e-03$ \\
\hline 280 & 199 & $7,765 \mathrm{e}-03$ & 181 & $7.166 \mathrm{e}-03$ & 163 & $6.607 \mathrm{e}-03$ \\
\hline 300 & 219 & $8.008 \mathrm{e}-03$ & 201 & $7,411 \mathrm{e}-03$ & 183 & $6.856 \mathrm{e}-03$ \\
\hline 320 & 239 & $8.236 \mathrm{e}-03$ & 221 & $7.640 \mathrm{e}-03$ & 203 & $7.088 \mathrm{e}-03$ \\
\hline 340 & 259 & $8.452 \mathrm{e}-03$ & 241 & $7.856 e-03$ & 223 & $7.305 \mathrm{e}-03$ \\
\hline
\end{tabular}


HNF-SD-TP-SEP-065 Rev. 0

ENGINEERING EVALUATION

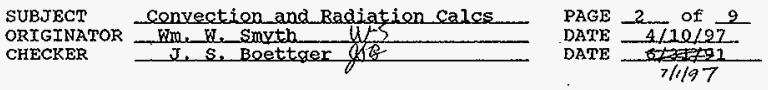

\begin{tabular}{|c|c|c|c|c|c|c|}
\hline \multirow[b]{2}{*}{$\begin{array}{r}\text { surface } \\
\text { temp }\end{array}$} & \multicolumn{2}{|c|}{ Tir terap } & \multicolumn{2}{|c|}{$\begin{array}{l}\text { air tomp } \\
T=99\left({ }^{\circ}\right)\end{array}$} & \multicolumn{2}{|c|}{$\begin{array}{r}\text { air temp } \\
T .=117\left({ }^{\circ} \mathrm{K}\right)\end{array}$} \\
\hline & $\Delta T$ & $\mathrm{~h}$ & $\Delta T$ & h & $\Delta T$ & $\mathrm{~h}$ \\
\hline$T_{w} \circ F$ & ${ }^{\circ} \mathrm{F}$ & $\begin{array}{l}\text { BTU/hr } \\
\text { inn of }\end{array}$ & ${ }^{\circ} \mathrm{F}$ & $\mathrm{L}^{\mathrm{BT}} \mathrm{R} / \mathrm{hr}$ & ${ }^{\circ} \mathrm{F}$ & $\begin{array}{l}\text { BTughr } \\
\text { /in }\end{array}$ \\
\hline 360 & 279 & $8.656 \mathrm{e}-03$ & 261 & $8.060 \mathrm{e}-03$ & 243 & $7.509 \mathrm{e}-03$ \\
\hline 380 & 299 & $8.851 e^{-03}$ & 281 & $8.253 \mathrm{e}-03$ & 263 & $7.702 \mathrm{e}-03$ \\
\hline 400 & 319 & $9.038 \mathrm{e}-03$ & 301 & $8.438 \mathrm{e}-03$ & 283 & $7.886 \mathrm{e}-03$ \\
\hline 420 & 339 & $9.217 \mathrm{e}-03$ & 321 & $8.614 \mathrm{e}-03$ & 303 & $8.061 \mathrm{e}-03$ \\
\hline 440 & 359 & $9.388 \mathrm{e}-03$ & $34 I$ & $8.783 \mathrm{e}-03$ & 323 & $8.228 \mathrm{e}-03$ \\
\hline 460 & 379 & $9.554 \mathrm{e}-03$ & 361 & $8.946 \mathrm{e}-03$ & 343 & $8.389 e-03$ \\
\hline 480 & 399 & $9.714 \mathrm{e}-03$ & 381 & $9.103 \mathrm{e}-03$ & 363 & $8.543 e-03$ \\
\hline 500 & 419 & $9.868 \mathrm{e}-03$ & 401 & $9.254 \mathrm{e}-03$ & 383 & $8.692 \mathrm{e}-03$ \\
\hline
\end{tabular}

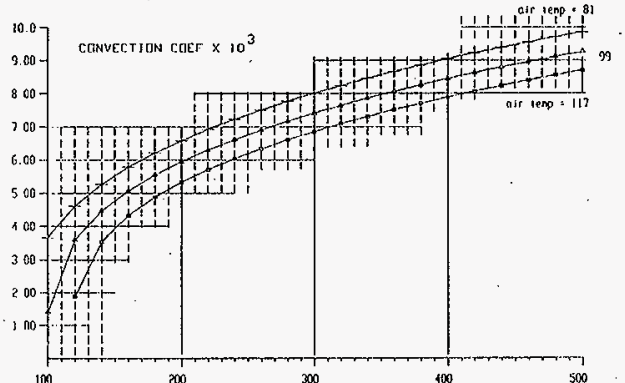




\section{ENGINEERING EVALUATION}
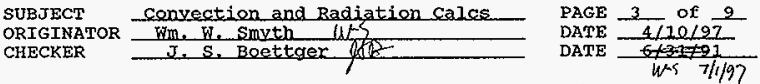

IV. Exaluation:

Calculate the free convection rate for a $1.12 \mathrm{~m}\left(44^{\prime \prime}\right)$ horizontal cylinder, in air, using the properties and methods from white's text. In the following table, $K$ and $\mathrm{Pr}$ are interpolated $\mathrm{linear} 7 \mathrm{y}$ and $\mathrm{Gr}$ is interpolated as a function of $\mathrm{T}^{5}$ : White provides values every $50^{\circ} \mathrm{K}$. Curves follow this table to show the reasonablness of the interpolations. The tables that follow use $\mathrm{Pr}, \mathrm{K}$, and $\mathrm{Gr}$ to calculate $\mathrm{h}$.

\begin{tabular}{|c|c|c|c|c|c|}
\hline \multicolumn{2}{|c|}{ air Temp } & $\begin{array}{c}K \\
W / m \times K\end{array}$ & $\operatorname{Pr}$ & $\begin{array}{l}g \beta / \nu^{2}= \\
\mathrm{Gr} /\left(D 3^{*} \Delta T\right)\end{array}$ & $\mathrm{Gr} / \Delta \mathrm{T}$ \\
\hline${ }^{\circ} \mathrm{K}$ & ${ }^{\circ} \mathrm{F}$ & & & & \\
\hline 200 & -99 & $1.81 \mathrm{e}-02$ & 0.740 & $8.57 e+08$ & $1.20 \mathrm{e}+09$ \\
\hline 210 & -81 & $1.89 \mathrm{e}-02$ & 0.737 & $6.78 \mathrm{e}+08$ & $9.53 e+08$ \\
\hline 220 & -63 & $1.98 e-02$ & 0.734 & $5.44 e+08$ & $7.64 \mathrm{e}+08$ \\
\hline 230 & -45 & $2.06 e-02$ & 0.730 & $4.42 \mathrm{e}+08$ & $6.21 e+08$ \\
\hline 240 & -27 & $2.15 \mathrm{e}-02$ & 0.727 & $3.63 e+08$ & $5.10 \mathrm{e}+08$ \\
\hline 250 & -9 & 2. $23 \mathrm{e}-02$ & 0.724 & $3.02 e+08$ & $4.24 \mathrm{e}+08$ \\
\hline 260 & 9 & $2.31 \mathrm{e}-02$ & 0.722 & $2.52 \mathrm{e}+08$ & $3.54 \mathrm{e}+08$ \\
\hline 270 & 27 & 2. $38 \mathrm{e}-02$ & 0.719 & $2.12 e+08$ & $2.97 e+08$ \\
\hline 280 & 45 & $2.46 e-02$ & 0.717 & $1.80 \mathrm{e}+08$ & $2.53 \mathrm{e}+08$ \\
\hline 290 & 63 & $2.53 \mathrm{e}-02$ & 0.714 & 1. $54 e+08$ & $2.16 e+08$ \\
\hline 300 & 81 & $2.61 \mathrm{e}-02$ & 0.712 & $1.33 \mathrm{e}+08$ & $1.87 e+08$ \\
\hline 310 & 99 & $2.68 \mathrm{e}-02$ & 0.711 & $1.14 e+08$ & $1.60 \mathrm{e}+08$ \\
\hline 320 & 117 & $2.75 e-02$ & 0.710 & $9.86 \mathrm{e}+07$ & $1.39 e+08$ \\
\hline 330 & 135 & $2.83 e-02$ & 0.708 & $8.57 e+07$ & $1.20 \mathrm{e}+08$ \\
\hline 340 & 153 & $2.90 \mathrm{e}-02$ & 0.707 & $7.50 \mathrm{e}+07$ & $1.05 e+08$ \\
\hline 350 & 171 & $2.97 \mathrm{e}-02$ & 0.706 & $6.60 \mathrm{e}+07$ & $9.27 \mathrm{e} \div 07$ \\
\hline 360 & 189 & $3.04 \mathrm{e}-02$ & 0.705 & $5.80 \mathrm{e}+07$ & $8.15 \mathrm{e}+07$ \\
\hline 370 & 207 & $3.11 \mathrm{e}-02$ & 0.705 & $5.12 \mathrm{e}+07$ & $7.19 \mathrm{e}+07$ \\
\hline
\end{tabular}


ENGINEERING EVALUATION

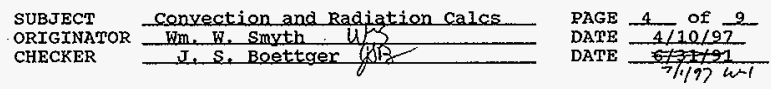

\begin{tabular}{|c|c|c|c|c|c|}
\hline \multicolumn{2}{|c|}{ air Temp } & \multirow{2}{*}{$\begin{array}{c}K \\
W / m^{*} K\end{array}$} & \multirow[t]{2}{*}{$\mathrm{Pr}$} & \multirow{2}{*}{$\begin{array}{l}g \beta / \nu^{*}= \\
\mathrm{Gr} /\left(03^{*} \Delta T\right)\end{array}$} & \multirow[t]{2}{*}{$\mathrm{Gr} / \Delta \mathrm{T}$} \\
\hline${ }^{\circ} \mathrm{K}$ & ${ }^{\circ} \mathrm{F}$ & & & & \\
\hline 380 & 225 & $3.17 e-02$ & 0.704 & $4.54 e+07$ & $6.38 e+07$ \\
\hline 390 & 243 & $3.24 \mathrm{e}-02$ & 0.704 & $4.05 \mathrm{e}+07$ & $5.69 \mathrm{e}+07$ \\
\hline 400 & 261 & $3.31 \mathrm{e}-02$ & 0.703 & $3.63 \mathrm{e}+07$ & $5.10 e+07$ \\
\hline 410 & 279 & $3.37 e-02$ & 0.702 & $3.25 e+07$ & $4.56 \mathrm{e}+07$ \\
\hline 420 & 297 & $3.44 e-02$ & 0.702 & $2.92 \mathrm{e}+07$ & $4.10 \mathrm{e}+07$ \\
\hline 430 & 315 & $3.50 e-02$ & 0.701 & $2.63 \mathrm{e}+07$ & $3.69 \mathrm{e}+07$ \\
\hline 440 & 333 & $3.57 \mathrm{e}-02$ & 0.701 & $2.38 \mathrm{e}+07$ & $3.34 e+07$ \\
\hline 450 & 351 & $3.63 \mathrm{e}-02$ & 0.700 & $2.16 e+07$ & $3.03 \mathrm{e}+07$ \\
\hline 460 & 369 & $3.69 \mathrm{e}-02$ & 0.700 & $1.96 \mathrm{e}+07$ & $2.75 \mathrm{e}+07$ \\
\hline 470 & 387 & $3.76 \mathrm{e}-02$ & 0.700 & $1.78 \mathrm{e}+07$ & $2.50 \mathrm{e}+07$ \\
\hline 480 & 405 & $3.82 \mathrm{e}-02$ & 0.699 & $1.62 \mathrm{e}+07$ & $2.28 \mathrm{e}+07$ \\
\hline 490 & 423 & $3.89 e-02$ & 0.699 & $1.48 e+07$ & $2.08 \mathrm{e}+07$ \\
\hline 500 & 441 & $3.95 \mathrm{e}-02$ & 0.699 & $1.36 \mathrm{e}+07$ & $1.91 \mathrm{e}+07$ \\
\hline
\end{tabular}


ENGINEERING EVALUATION

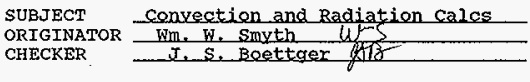

PAGE $\frac{5}{4 / 10 / 97}$ of $\frac{9}{127}$
DATE ORIGINA

DATE $\frac{1 / 197 \mathrm{mi}}{7 / 1 / 9}$

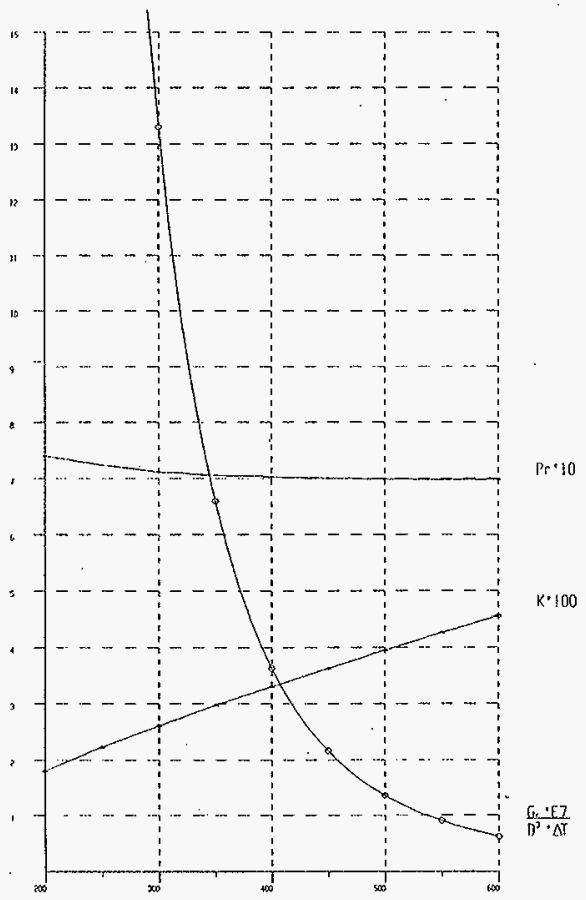




\section{ENGINEERING EVALUATION}

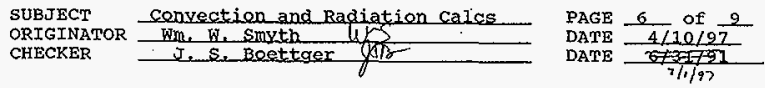

Using White's methodology (chapter 7) and materiat properties, find the convection coefficient at various air temperatures and temperature differences.
$q$ is the heat transfer rate over $A$
$A$ is the wall area
$T_{w}=$ the wall temperature
$T_{.}=$the environment temperature.
$\mathrm{k}=$ conductivity of $\mathrm{air}, \mathrm{W} / \mathrm{m}-\mathrm{K}$

$$
\begin{gathered}
q-A \cdot h \cdot\left(T w-T_{u}\right) \\
h=\frac{k \cdot N_{u}}{D} \\
\sqrt{N_{1}}=.6+\frac{0.387 R_{a D}{ }^{1 / 6}}{\left[1+\left(\cdot \frac{559}{P_{x}}\right)^{9 / 26}\right]^{8 / 27}} \\
R_{A D}=G_{z D} \cdot R_{x}
\end{gathered}
$$

$\mathrm{N}_{\mathrm{u}}=$ Nusselt Number

$R_{a b}=$ Rayleigh number for cylinder

The following tables were generated by a spreadsheet. The air temperature is taken from the data in the tables above, since they are convenient. The Grashoff mumber

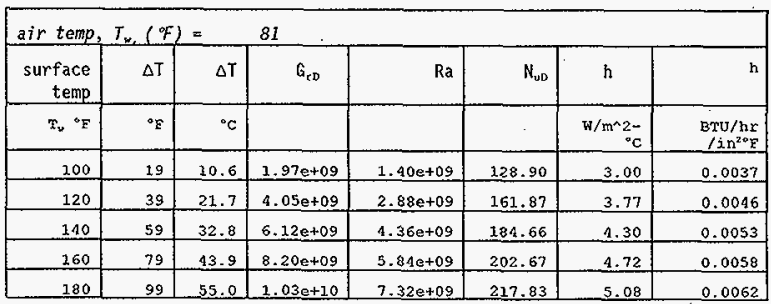




\section{ENGINEERING EVALUATION}

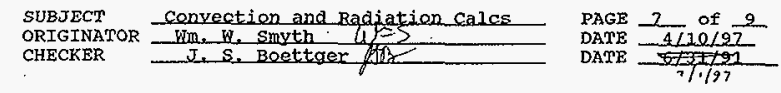

\begin{tabular}{|c|c|c|c|c|c|c|c|}
\hline \multicolumn{3}{|c|}{ air temp, $T_{n}($ of $)$} & \multicolumn{5}{|l|}{81} \\
\hline $\begin{array}{r}\text { surface } \\
\text { temp }\end{array}$ & $\Delta \mathrm{T}$ & $\Delta \mathrm{T}$ & $G_{s D}$ & $\mathrm{Ra}$ & $N_{W D}$ & h & $\mathbf{n}$ \\
\hline $\mathrm{T}_{v}{ }^{\circ} \mathrm{F}$ & ${ }^{\circ} \mathrm{F}$ & ${ }^{\circ} \mathrm{C}$ & & & & $\begin{array}{r}W / \mathrm{m}^{\wedge}{ }^{2} \cdot- \\
{ }^{\circ} \mathrm{C} \\
\end{array}$ & $\begin{array}{r}\mathrm{BFU} / \mathrm{hr} \\
/ \operatorname{in}^{2 \circ \mathrm{F}}\end{array}$ \\
\hline 200 & 219 & 66.1 & $1.24 e+10$ & $8.800+09$ & 232.04 & 5.38 & 0.0066 \\
\hline 220 & 239 & 77.2 & $1.44 \mathrm{e}+10$ & $1.03 e+1.0$ & 242.83 & 5.66 & $6.92 \mathrm{e}-03$ \\
\hline 240 & 159 & 88.3 & $1.65 \mathrm{e}+10$ & $1.18 \mathrm{e}+10$ & 253.52 & 5.91 & $7.23 \mathrm{e}-03$ \\
\hline 260 & 179 & 99.4 & $1.86 e+10$ & $1.32 e+10$ & 263.35 & 6.24 & $7.52 \mathrm{e}-03$ \\
\hline 280 & 199 & 130.6 & $2.07 \mathrm{e}+10$ & $1.47 \mathrm{e}+10$ & 272.46 & 6.35 & $7.77 \mathrm{e}-03$ \\
\hline 300 & 219 & 121.7 & $2.27 \mathrm{e}+1.0$ & 1. $62 \mathrm{e}+10$ & 280.97 & 6.55 & $8.01 \mathrm{e}-03$ \\
\hline 320 & 239 & 132.8 & $2.48 e+10$ & $1.77 \mathrm{e}+10$ & 288.98 & 6.73 & $8.24 \mathrm{e}-03$ \\
\hline 340 & 259 & 2.43 .9 & $2.69 \mathrm{e}+10$ & $1.91 \mathrm{e}+10$ & 296.55 & 5.91 & 8. $45 e-03$ \\
\hline 360 & 279 & 155.0 & $2.90 e+10$ & $2.06 \mathrm{e}+10$ & 303.73 & 7.08 & $\dot{8} .66 \mathrm{e}-03$ \\
\hline 380 & 299 & 166.1 & $3.10 e+10$ & $2.21 e+10$ & 310.57 & 7.24 & $8.85 e-03$ \\
\hline 400 & 319 & 277.2 & $3.310+10$ & $2.36 \mathrm{e}+10$ & 317.12 & 7.39 & $9.04 e-03$ \\
\hline 420 & 339 & 188.3 & $3.52 e+20$ & $2.510+10$ & 323.39 & 7.54 & $9.22 \mathrm{e}-03$ \\
\hline 440 & 359 & 199.4 & $3.73 e+10$ & $2.65 \mathrm{e}+10$ & 329.42 & 7.68 & $9.39 \mathrm{e}-03$ \\
\hline 460 & 379 & 230.6 & $3.93 e+10$ & $2.800+20$ & 335.23 & 7.81 & $9.55 e-03$ \\
\hline 480 & 399 & 221.7 & $4.14 \mathrm{e}+10$ & $2.95 \mathrm{e}+10$ & 340.83 & 7.94 & $9.710-03$ \\
\hline 500 & 419 & 232.8 & 4. $35 e+10$ & $3.10 \mathrm{e}+10$ & 346.25 & 8.07 & $9.870-03$ \\
\hline
\end{tabular}

\begin{tabular}{|c|c|c|c|c|c|c|c|}
\hline \multicolumn{8}{|c|}{ aix temp, $T_{u_{2}}\left({ }^{\circ} F\right)=99$} \\
\hline $\begin{array}{r}\text { surface } \\
\text { temp } \\
\end{array}$ & $\Delta T$ & $\Delta \mathrm{T}$ & & & & & n \\
\hline$T_{*} \cap F$ & ${ }^{\circ} \mathrm{g}$ & ${ }^{\circ} \mathrm{C}$ & $G_{r 0}$ & - Ra & $\mathrm{N}_{\mathrm{up}}$ & $W / m^{2 \cdot \circ} \mathrm{C}$ & $\begin{array}{r}B T U / h_{F} / \\
\operatorname{in}^{20}=\end{array}$ \\
\hline 100 & 1 & 0.6 & $8.91 \mathrm{e}+0 \mathrm{z}$ & $6.33 e+07$ & 49.21 & 1.15 & $1.40 \mathrm{e}-03$ \\
\hline 120 & 21 & 11.7 & $1.87 \mathrm{e}+09$ & $1.33 \mathrm{e}+09$ & 126.67 & 2.95 & $3.61 \mathrm{e}-03$ \\
\hline 140 & 41 & 22.8 & $3.65 e+09$ & $2.60 \mathrm{e}+09$ & 156.55 & 3.65 & $4.46 \mathrm{e}-03$ \\
\hline 160 & 61 & 33.9 & $5.43 e+09$ & $3.86 \mathrm{e}+09$ & 177.62 & 4.14 & $5.06 \mathrm{e}-03$ \\
\hline 180 & 81 & 45.0 & $7.22 \mathrm{e}+09$ & $5.13 e+09$ & 194.42 & 4.53 & $5.54 e-03$ \\
\hline 200 & 101 & 56.1 & $9.00 e+09$ & $6.40 e+09$ & 208.61 & 4.86 & $5.950-03$ \\
\hline 220 & 121 & 67.2 & $1.08 \mathrm{e}+10$ & $7.66 \mathrm{e}+09$ & 221.01 & 5.15 & $6.30 \mathrm{e}-03$ \\
\hline
\end{tabular}




\section{ENGINEERING EVALUATION}

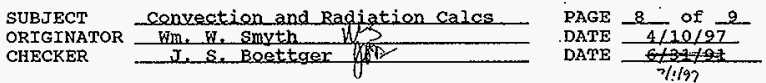

\begin{tabular}{|c|c|c|c|c|c|c|c|}
\hline air temp & $r_{v,}\left({ }^{\circ} E\right)$ & 99 & & & & & \\
\hline $\begin{array}{r}\text { surface } \\
\text { temp }\end{array}$ & $\Delta \mathrm{T}$ & $\Delta r$ & & $\cdot$ & & $\mathbf{h}$ & $\mathrm{h}$ \\
\hline $\mathbf{T}_{\mathbf{w}}{ }^{\circ} \mathbf{F}$ & ${ }^{\circ} \mathrm{E}$ & ${ }^{\circ} \mathrm{C}$ & $G_{\mathrm{rD}}$ & $\mathrm{Ra}$ & $N_{\Delta D}$ & $\mathrm{H} / \mathrm{m}^{2 \circ} \mathrm{C}$ & $\begin{array}{r}\text { BTt/hrf } \\
\mathrm{in}^{2 \circ} \mathrm{F}\end{array}$ \\
\hline 240 & 141 & 78.3 & 1. $26 \mathrm{e}+10$ & $8.93 \mathrm{e}+09$ & 232.10 & 5.41 & $6.61 e-03$ \\
\hline 260 & 161 & 89.4 & I. $43 \mathrm{e}+10$ & $1.02 \mathrm{e}+10$ & 242.17 & 5.64 & $6.90 e-03$ \\
\hline 280 & 181 & 100.6 & $1.61 \mathrm{e}+10$ & $1.15 e+10$ & 251.44 & 5.86 & $7.17 e-03$ \\
\hline 300 & 201 & 1.11 .7 & $1.79 e+30$ & 1. $27 e+10^{\circ}$ & 260.04 & 6.06 & $7.41 e-03$ \\
\hline 320 & 221 & 122.8 & $1.97 e+10$ & $1.40 \mathrm{e}+10$ & 268.08 & 6.25 & $7.64 e-03$ \\
\hline 340 & 241 & 133.9 & $2.15 e+10$ & $1.53 \mathrm{e}+10$ & 275.64 & 6.42 & $7.86 e-03$ \\
\hline 360 & 261 & 145.0 & $2.33 e+10$ & $1.65 e+10$ & 282.79 & 6.59 & $8.06 e-03$ \\
\hline 380 & 281 & 156.1 & $2.50 e+10$ & $1.78 \mathrm{e}+10$ & 289.59 & 6.75 & $8.25 \mathrm{e}-03$ \\
\hline 400 & 301 & 167.2 & $2.68 e+20$ & $1.92 e+10$ & 296.06 & 6.90 & $8.44 e-03$ \\
\hline 420 & 321 & 178.3 & $2.86 \mathrm{e}+20$ & $2.030+10$ & 302.25 & 7.04 & $8.61 e-03$ \\
\hline 440 & 341 & 189.4 & $3.04 e+10$ & $2.16 e+10$ & 308.19 & 7.18 & $8.78 \mathrm{e}-03$ \\
\hline 460 & 361 & 200.6 & $3.22 \mathrm{e}+10$ & $2.29 e+10$ & 313.90 & 7.32 & $8.95 e-03$ \\
\hline 480 & 381 & 211.7 & $3.39 e+10$ & 2. $41 e+10$ & 319.40 & 7.44 & $9.20 \mathrm{e}-03$ \\
\hline 500 & 401 & 222.8 & $3.57 e+10$ & $2.54 \mathrm{e}+10$ & 324.71 & 7.57 & $9.25 e-03$ \\
\hline
\end{tabular}

\begin{tabular}{|c|c|c|c|c|c|c|c|}
\hline air teme & ${ }^{\circ}$ ) $=$ & 227 & & & & & \\
\hline $\begin{array}{r}\text { surface } \\
\text { temp }\end{array}$ & $\Delta T$ & $\Delta \mathrm{T}$ & $G r_{0}$ & Rad & Nud & h & h \\
\hline$T_{N}{ }^{0} \mathbf{F}$ & ${ }^{\circ} \mathrm{F}$ & ${ }^{\circ} \mathrm{C}$ & & & & $\mathrm{w} / \mathrm{m}^{2}-{ }^{\circ} \mathrm{C}$ & $\begin{array}{c}\mathrm{BTU} / \mathrm{hr} / \\
\quad \mathrm{in}^{20 \mathrm{~F}}\end{array}$ \\
\hline 120 & 3 & 1.7 & $2.31 \mathrm{e}+08$ & $1.64 \mathrm{e}+08$ & 65.85 & 1.53 & $1.877 \mathrm{e}-03$ \\
\hline 140 & 41 & 22.8 & $3.16 \mathrm{e}+09$ & $2.24 \mathrm{e}+09$ & 149.33 & 3.48 & $4.256 e-03$ \\
\hline 160 & 61 & 33.9 & $4.70 e+09$ & $3.33 e+09$ & 169.91 & 3.95 & $4.828 \mathrm{e}-03$ \\
\hline 180 & 81 & 45.0 & $6.23 e+09$ & $4.42 e+09$ & 185.41 & 4.32 & 5. $284 \mathrm{e}-03$ \\
\hline 200 & 101 & 56.1 & 7.770409 & $5.52 e+09$ & 298.93 & 4.64 & $5.669 e-03$ \\
\hline 220 & 121 & 67.2 & $9.31 e+09$ & $6.61 \mathrm{e}+09$ & 210.74 & 4.91 & $6.006 \mathrm{e}-03$ \\
\hline 240 & 141 & 78.3 & $1.09 \mathrm{e}+10$ & $7.70 \mathrm{e}+09$ & 221.31 & 5.16 & $6.307 \mathrm{e}-03$ \\
\hline 260 & 161 & 89.4 & $1.21 \mathrm{e}+10$ & $8.79 e+09$ & 230.90 & 5.38 & $6.58 \mathrm{de}-03$ \\
\hline 280 & 181 & 100.6 & $1.390+10$ & $9.89 e+09$ & 239.73 & 5.59 & $6.832 \mathrm{e}-03$ \\
\hline
\end{tabular}


EOJLQHHULQJ\#HYDOXDWLRQ

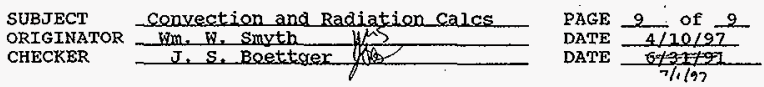

\begin{tabular}{|c|c|c|c|c|c|c|c|}
\hline air temp & $\left({ }^{a} E\right)=$ & 117 & & & & & \\
\hline $\begin{array}{r}\text { surface } \\
\text { temp }\end{array}$ & $\Delta \mathrm{T}$ & $\Delta T$ & $G x_{n}$ & Rad & Nud & $\mathrm{n}$ & $\mathrm{h}$ \\
\hline $\mathrm{T}_{Y} \cdot \mathrm{F}$ & ${ }^{\circ} \mathrm{g}$ & ${ }^{\circ} \mathrm{C}$ & & & & $w / m^{2}-{ }^{\infty} \mathrm{C}$ & $\begin{array}{c}\mathrm{BTU} / \mathrm{hr} / \\
\operatorname{in}^{2 \circ} \mathrm{F}\end{array}$ \\
\hline 300 & 201 & 112.7 & $1.550+10$ & $1.10 e+10$ & $2 \pi 7.92$ & 5.78 & $7.066 e-03$ \\
\hline 320 & 221 & 122.8 & $1.70 e+10$ & $1.21 \mathrm{e}+10$ & 255.58 & 5.96 & $7.284 \mathrm{e}-03$ \\
\hline 340 & 241 & .133 .9 & $1.85 \mathrm{e}+10$ & 1. $32 \mathrm{e}+10$ & 262.78 & 6.12 & 7. $489 \mathrm{e}-03$ \\
\hline 360 & 261 & 145.0 & $2.01 \mathrm{e}+10$ & $1.430+10$ & 269.59 & 6.28 & $7.6830-03$ \\
\hline 380 & 281 & 256.1 & $2.16 e+10$ & $1.53 \mathrm{e}+20$ & 276.06 & 6.43 & $7.868 \mathrm{e}-03$ \\
\hline 400 & 301 & 167.2 & $2.32 \mathrm{e}+10$ & T. $64 \mathrm{e}+10$ & 282.23 & 6.58 & $8.044 \mathrm{e}-03$ \\
\hline 420 & 321 & 178.3 & $2.47 \mathrm{e}+10$ & 1.75e+10 & 288.13 & 6.71 & $8.212 \mathrm{e}-03$ \\
\hline 440 & 341 & 189.4 & $2.62 \mathrm{e}+10$ & 1.86e+10 & 293.78 & 6.85 & 8. $373 e^{-03}$ \\
\hline 460 & 361 & 200.6 & $2.78 \mathrm{e}+10$ & $1.97 e+10$ & 299.22 & 6.97 & 8. $528 \mathrm{e}-0.3$ \\
\hline 480 & 381 & 211.7 & $2.93 e+10$ & $2.08 \mathrm{e}+10$ & 30.4 .46 & 7.10 & $8.677 e-03$ \\
\hline 500 & 401 & 222.8 & $3.09 e+10$ & $2.19 \mathrm{e}+10$ & 309.52 & 7.21 & $3.821 e-03$ \\
\hline 520 & 421 & 233.9 & $3.29 \mathrm{e}+10$ & $2.30 e+10$ & 314.40 & 7.33 & $8.961 e-03$ \\
\hline
\end{tabular}

Note that the SARP's convection coefficient of $5 \mathrm{k} / \mathrm{m}^{2} \mathrm{~K}$ requires a surface temperature of about $230^{\circ} \mathrm{F}$ when the air temperature is $117^{\circ} \mathrm{F}$ and 210 in $100^{\circ} \mathrm{F}$ air. This is approximately what is found for the analysis results, but a variable convection rate was used in the SEP analysis based on the results for $117^{\circ} \mathrm{F}$ air. 


\subsubsection{Capsule Arrangement in Cask}

ENGINEERING SAEETY EVALUATION

\begin{tabular}{|c|c|c|}
\hline Subject & CAPSULE ARRANGEMENT FOR $16 \mathrm{CSCl}$ CAPSULES IN BUSS & Page 1 of 1 \\
\hline $\begin{array}{l}\text { Originator } \\
\text { Checker }\end{array}$ & 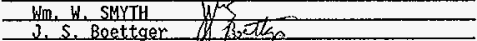 & $\begin{array}{l}\text { Date } \frac{4 / 11 / 97}{711 / 77} \\
\text { Date }\end{array}$ \\
\hline
\end{tabular}

I. Objective: Determine the best capsuTe arrangement in the BUSS to minimize the average temperate in a $45^{\circ}$ segment. This will be the temperature used in the thermal analysis, and the arrangement will be controlled in the operations section.

I1. References:

III. Results and conclusions: The maximum average is $193.4 \mathrm{~W}$ per segment. This will require administrative controls to assure this is not exceeded.

IV. Evaluation:

AVERAGE THERMAL POWER N OCTANT A:

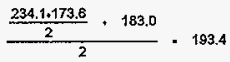

AVERAGE THERMAL POWER IN OCTANT B:
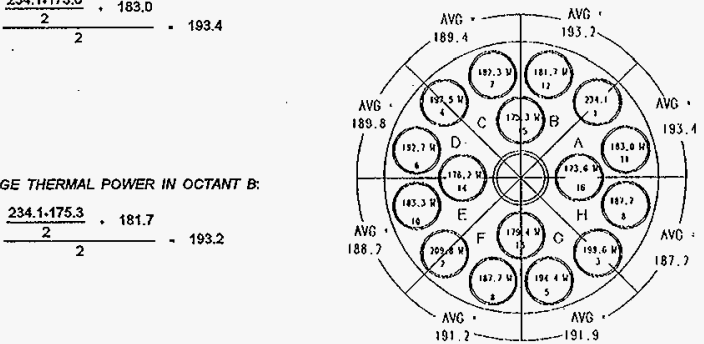


\subsubsection{Finite Element Analysis of SARP Configuration}

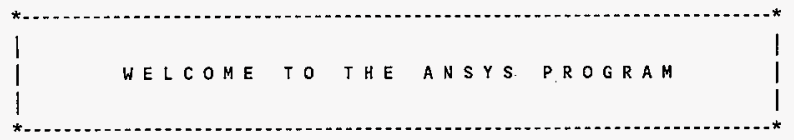

BATCH MODE REQUESTED

\begin{tabular}{|c|c|c|c|c|c|}
\hline WORK SPACE REQUESTED & $=$ & 8388608 & 32.000 & MB & DEFAULT \\
\hline MINIMUM WORK SPACE REQUIRED & $=$ & 4718592 & 18.000 & MB & \\
\hline MINIMUM WORK SPACE RECOMMENDED & $=$ & 6702496 & 25.568 & MB & \\
\hline WORK SPACE OBTAINED & $=$ & 8388606 & 32.000 & $M B$ & \\
\hline BYTES PER WORD & $=$ & 4 & & & \\
\hline
\end{tabular}

***** NOTICE ****** THIS IS THE ANSYS GENERAL PURPOSE

FINITE ELEMENT COMPUTER PROGRAM. NEITHER SWANSON ANALYSIS

SYSTEMS, INC. NOR THE DISTRIBUTOR SUPPLYING THIS PROGRAM ASSUME ANY RESPONSIBILITY FOR THE VALIDITY, ACCURACY, OR APPLICABILITY OF ANY RESULTS OBTAINED FROM THE ANSYS SYSTEM. USERS MUST VERIFY THEIR OWN RESULTS.

ANSYS(R) COPYRIGHTO 1971, 1978, 1982, 1983, 1985, 1987, 1989, 1992, 1993 . BY SWANSON ANALYSIS SYSTEMS, INC. AS AN UNPUBLISHED WORK. PROPRIETARY DATA - UNAUTHORIZED USE, DISTRIBUTION, OR DUPLICATION IS PROHIBITEO. ALL RIGHTS RESERVED.

SWANSON ANALYSIS SYSIEMS, INC. IS ENDEAVORING TO MAKE THE ANSYS PROGRAM AS COMPLETE, ACCURATE, AND EASY TO USE AS POSSIBLE. SUGGESTIONS AND COMMENTS ARE WELCOMED. ANY ERRORS ENCOUNTERED IN EITHER THE DOCUMENTATION OR THE RESULTS SHOULD BE IMMEDIATELY BROUGHT TO OUR AIIENTION.

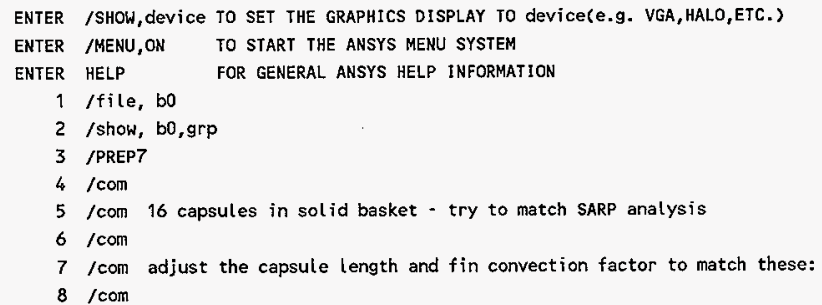




\section{HNF-SD-TP-SEP-065 Rev. 0}

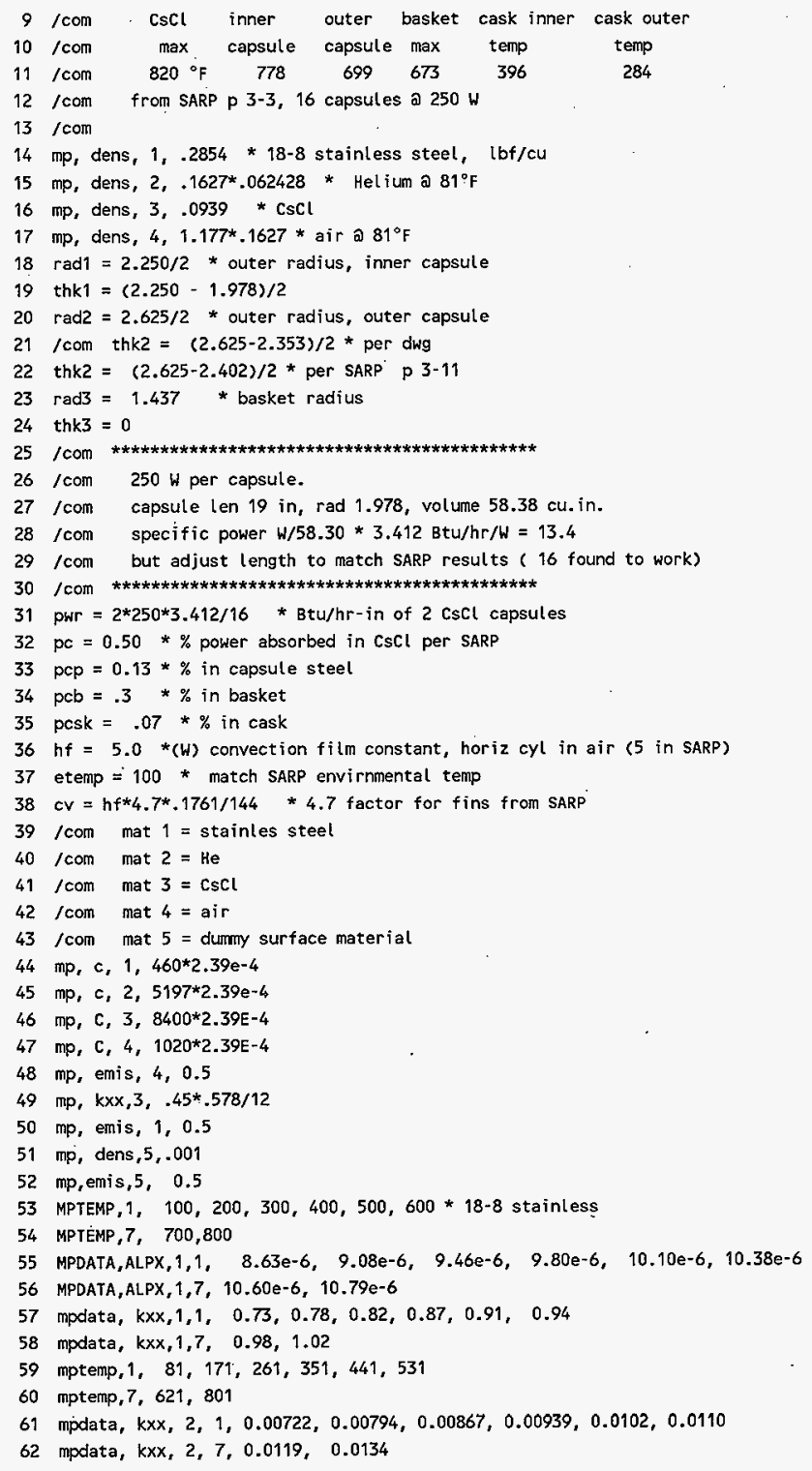




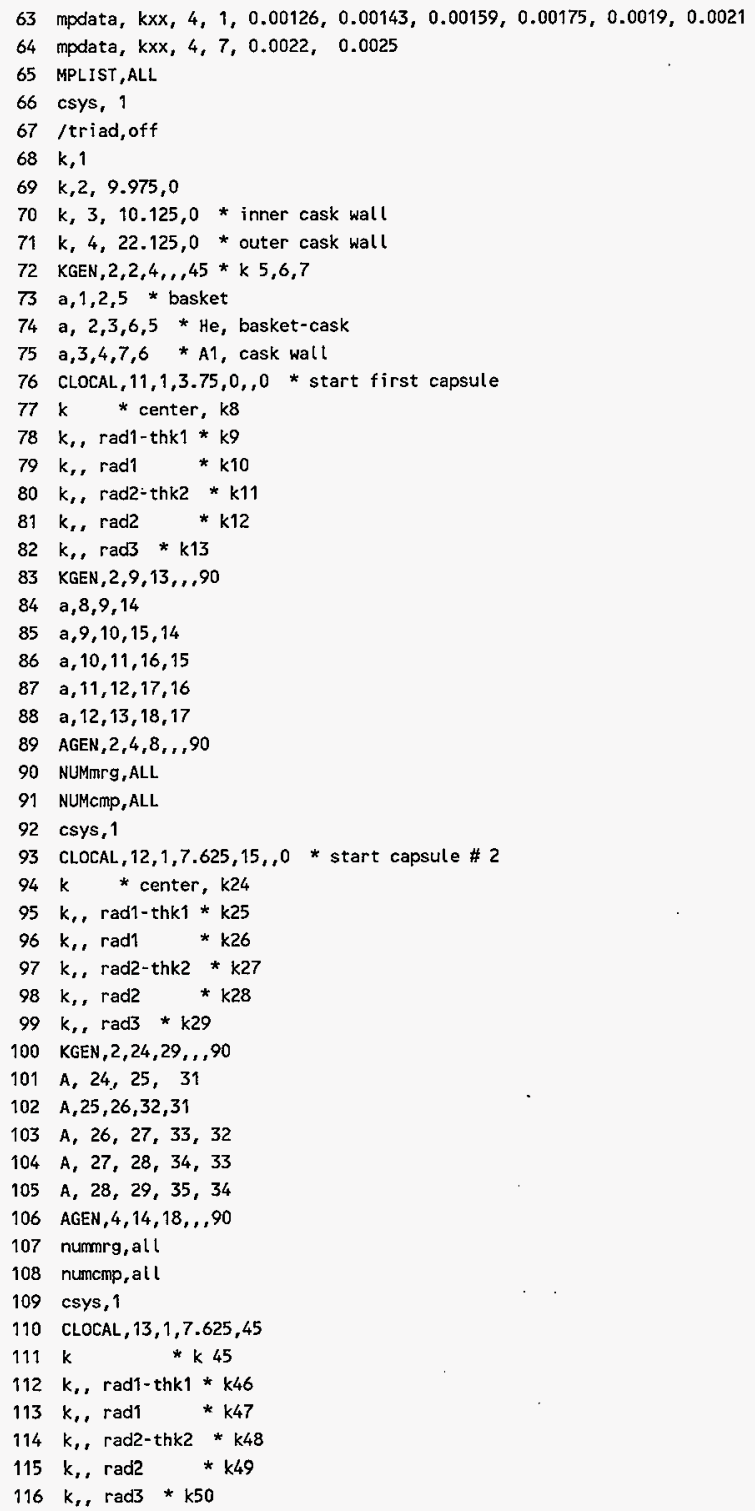




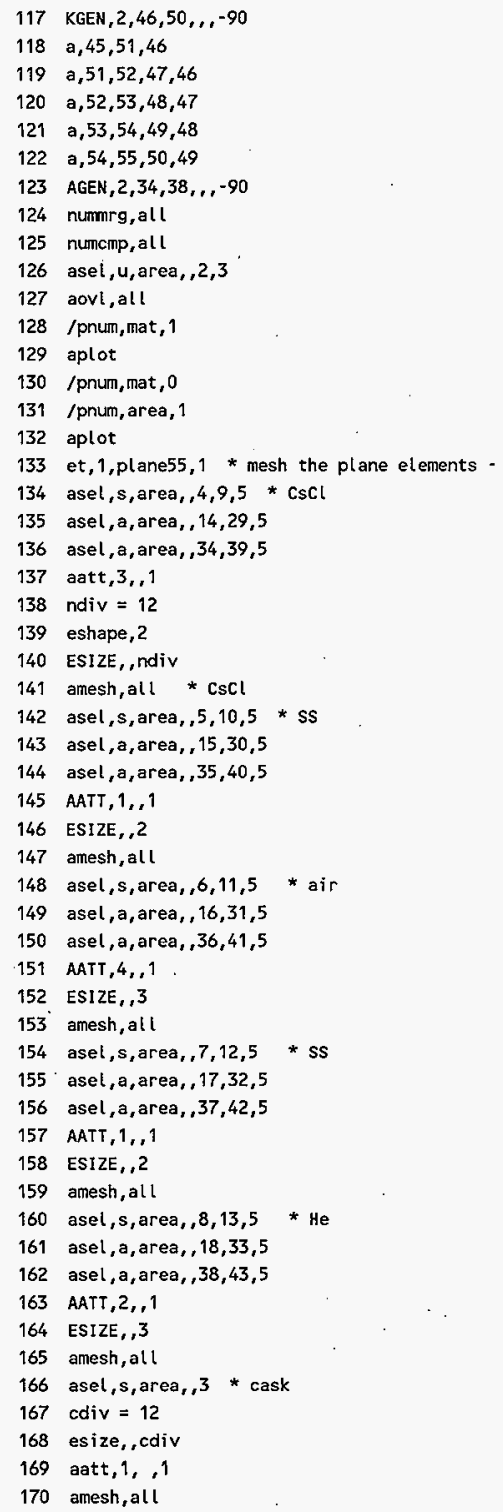




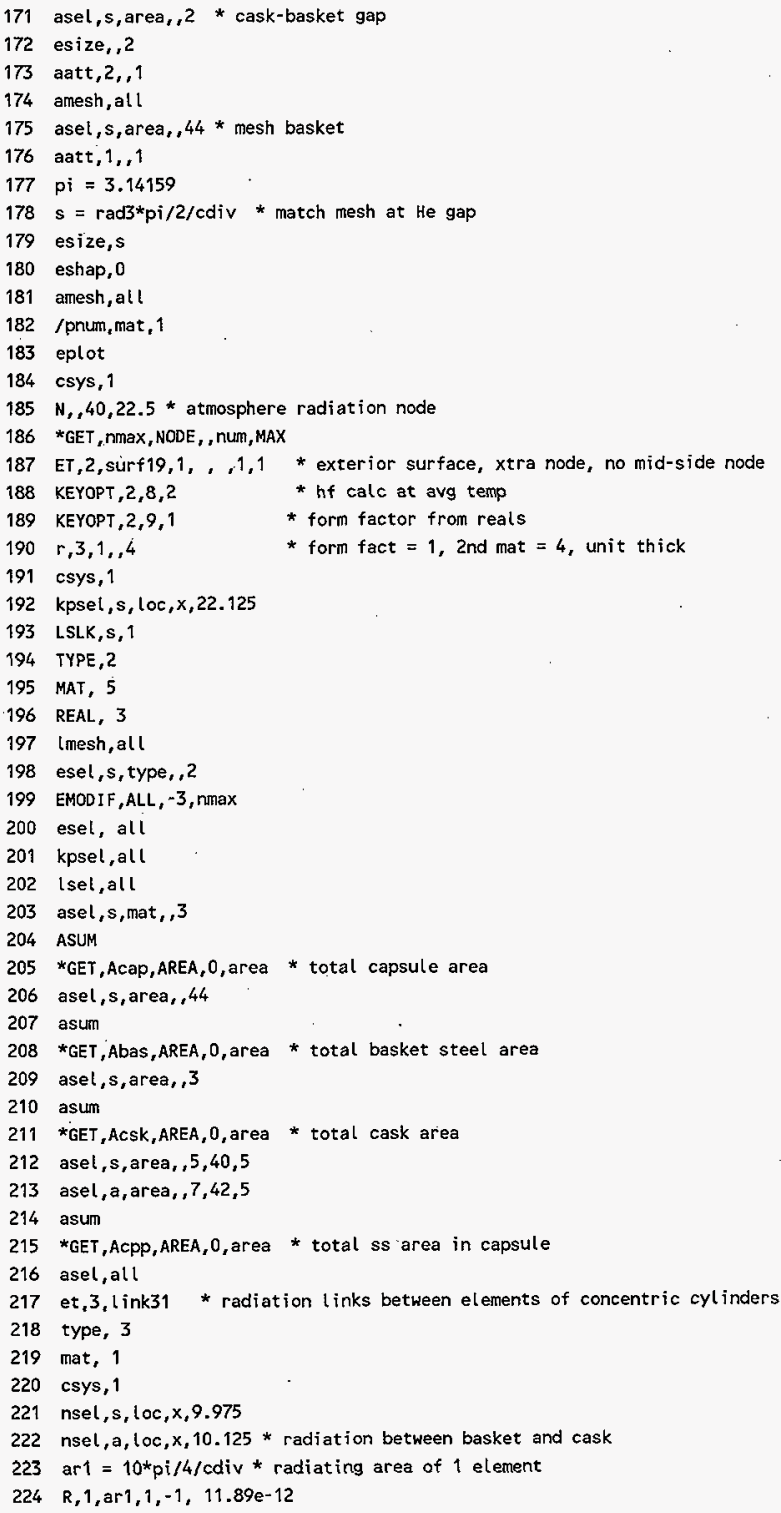




\section{HNF-SD-TP-SEP-065 Rev. 0}

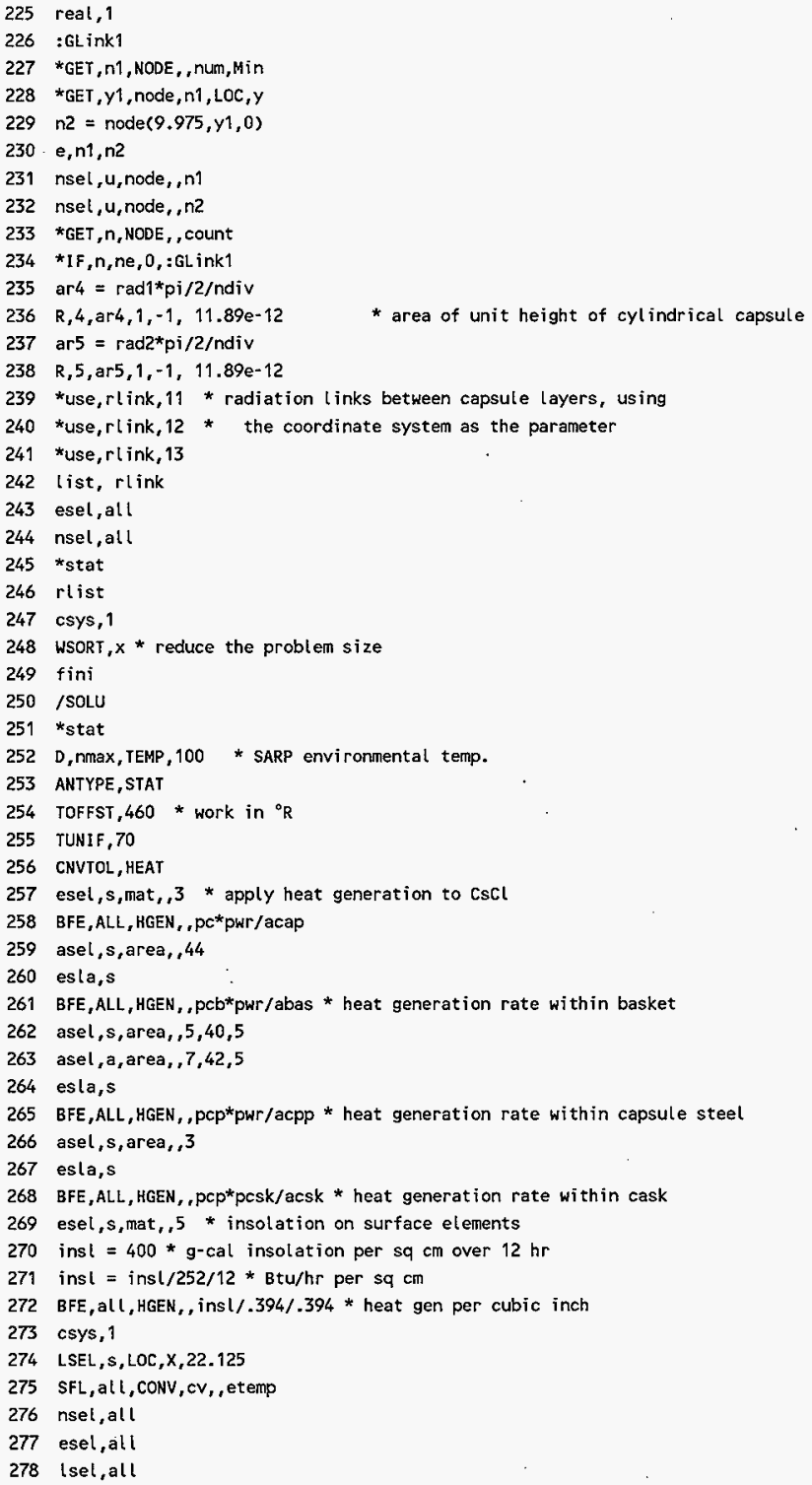


HNF-SD-TP-SEP-065 Rev. 0

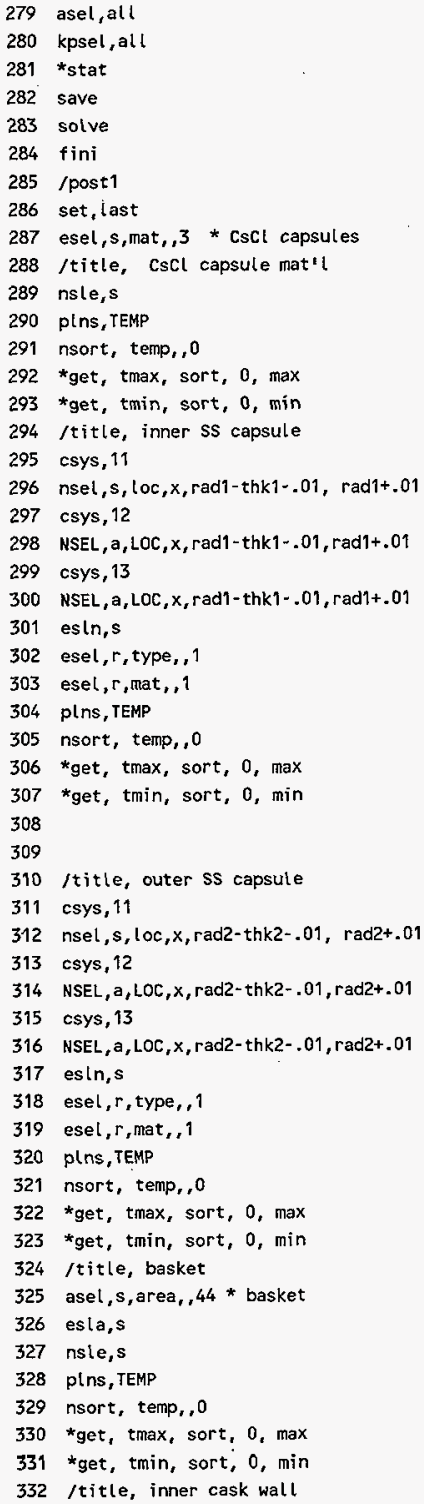


333 csys, 1

334 nsel, s, loc, $x, 10.125$

335 es $\ln , \mathrm{s}$

336 esel, a, mat, , 1

337 pins, TEMP

338 nsort, temp, , 0

339 *get, tmax, sort, 0, max

340 *get, tmin, sort, 0, min

341 /title, outer cask wall

342 nsel, s, loc, x, 22.125

343 esln,s

344 esel, a, mat, , 1

345 plns, TEMP

346 nsort, temp, 0

347 *get, tmax, sort, 0, max

348 *get, tmin, sort, 0, min

349 fini

350 lexit

351

CURRENT JOBNAME REDEFINED AS bO 


\subsubsection{Finite Element Analysis of 16 Overpacked Capsules in an Open Basket}

Running ANSYS 5.2 on workstation: sgi3 on: Thu Jul 10 09:04:04 PDT 1997

ANSYS 5.2 has been verified by ICF $K H$

Class 3 Error Reports are in the directory: /apps/ansys/class3_errors. Executing /apps/ansys/sgi/ansys52/bin/ansys.e52

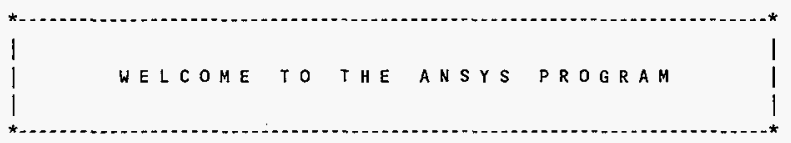

$\begin{array}{lll}* * * * * & \text { DISCLAIMER OF WARRANTY } & * * * * * \\ * * * * * & \text { AND NOTICE OF COPYRIGHT } & * * * * *\end{array}$

This ANSYS(R) software product (the Program), its Help system (Help system), and program documentation (Documentation) are furnished by ANSYS, Inc. under an ANSYS License Agreement that contains provisions concerning non-disclosure, copying, length and nature of use, warranties, disclaimers and remedies, and other provisions. The Program may be used or copied only in accordance with the terms of that License Agreement. Some of those terms are summarized here.

The Program should only be used by qualified persons. The determination as to who is qualified to use the Program is the obligation of the Licensee under the License Agreement.

NEITHER ANSYS, INC. NOR THE DISTRIBUTOR SUPPLYING THE PROGRAN (THE DISTRIBUTOR) GUARANTEES THE USEFULNESS OF THE RESULTS OF ANY ANALYSIS PERFORMED WITH THIS PROGRAM, ITS HELP SYSTEM, OR DOCUMENTATION. It is the responsibility of the Licensee or user to confirm the usefulness and accuracy of all the solutions.

The Help System and Documentation consist of the ANSYS User's Manual and various other manuals. The User's Manual consists ONLY of the following four volumes: Procedures, Commands, Elements, and Theory. The User's Manual is identified with the words "ANSYS User's Manual" at the bottom of each page.

EXCEPT AS PROVIDED IN THE LICENSE AGREEMENT, NEIIHER ANSYS, INC. NOR THE DISTRIBUTOR SHALL BE LIABLE FOR THE NEGLIGENT PREPARATION OF THE PROGRAM, THE HELP SYSTEM, OR USER'S MANUAL; OR FOR ANY TECHNICAL, EDITORIAL, OR OTHER ERRORS OR OMISSIONS WHICH THE HELP SYSTEN OR USER'S MANUAL MIGHT CONTAIN. ANSYS, INC. SHALL NOT BE LIABLE FOR INCIDENTAL, CONSEQUENTIAL, COMPENSATORY OR EXEMPLARY DAMAGES RESULTING FROM ANY SUCH NEGLIGENT PREPARATION OR ERROR. 
EXCEPT AS PROVIDED IN THE LICENSE AGREEMENT, ANSYS, INC. AND THE DISTRIBUTOR HEREBY DISCLAIM ANY EXPRESS OR IMPLIED WARRANTY, INCLUDING BUT NOT LIMITED TO, THE WARRANTY OF MERCHANTABILITY OR FITNESS FOR A PARTICULAR PURPOSE WITH REGARD TO THE PROGRAM OR THE CONTENTS, INFORMATION, AND INSTRUCTIONS CONTAINED IN THE HELP SYSTEM OR USER'S MANUAL, WHETHER SAID WARRANTIES ARISE UNDER PROVISIONS OF ANY LAW OF THE UNITED STATES OF AMERICA OR ANY STATE THEREOF OR ANY OTHER COUNTRY, OR PURSUANT TO THE PROVISIONS OF THE UNITED NATIONS CONVENTION ON CONTRACTS FOR THE INTERNATIONAL SALE OF GOODS.

Examples, solutions, theories, results, methods, and references to other documents are provided in the Help System and User's Manual for guidance and explanation only. THEY ARE NOT GUARANTEED TO PROVIDE THE USER WITH THE MOST ACCURATE, USEFUL, OR CORRECT ANALYSIS FOR ANY PARTICULAR PROBLEM.

The Program, Help System, and Documentation are protected by United States copyright law. You may print pages from the help System to a printer for your own personal use. You may not further copy or reproduce such pages in any form without the prior written permission of ANSY, Inc.

ANSY, Inc. is endeavoring to make the ANSYS program as complete, accurate, and easy to use as possible. suggestions and comments are welcome. Please bring any errors in either the Documentation or the Program results to the attention of ANSY, Inc. by contacting your Distributor.

Copyright 1971, 1978, 1982, 1983, 1985, 1987, 1989, 1992, 1993, 1994, 1995 by SAS IP as an unpublished work. Proprietary data--unathorized use, distribution, or duplication, is prohibited. All rights reserved.

AFTER YOU HAVE READ AND UNDERSTOOD THE PREVIOUS DISCLAIMER, PRESS <CR> OR <ENTER> TO CONTINUE

$\star \star \star * \star$ ANSYS COMMAND LINE ARGUMENTS $* * * * *$

NONE

*** NOTE *** $\quad \mathrm{CP}=3.680$ TIME= 09:04:14

There are no parameters and no abbreviations defined.

32207

VERSION=SGI IRIS4D REVISION $=5.2$

FOR SUPPORT CALL K MCMillian 373- PHONE $U$ LR 206-353-8089 FAX FAX 509-373-6975

CURRENT JOBNAME=file 09:04:14 JUL 10, $1997 \mathrm{CP}=\quad 3.690$

RUN SETUP PROCEDURE FROM FILE= /apps/ansys/sgi/ansys52/docu/start.ans

/INPUT FILE $=$ /apps/ansys/sgi/ansys52/docu/start.ans LINE= 
$2 / f i l e$, b16a

3 /show, b16, 9

4 ITYPE,ALL, hidp

5 /PREP7

$6 / \mathrm{com}$

7 /com STATIC ANALYSIS

8 /com 16 capsules in overpacks, no basket

9 /com CsCt temp limit is $842^{\circ} \mathrm{F}$ at ss interface

$10 /$ con $\mathrm{CsCl}$ melt temp $1195^{\circ} \mathrm{F}$

11 /com phase change between $350-470^{\circ} \mathrm{C}=662-878^{\circ} \mathrm{F}$

$12 / \mathrm{com}$ test temperature $800^{\circ} \mathrm{C}=1472{ }^{\circ} \mathrm{F}$

$13 /$ com model $45^{\circ}$ arc containing 1 complete +2 half capsules

$14 / \mathrm{com}$

15 mp, dens, 1,.2854*18-8 stainless steel, lbf/cu in

$16 \mathrm{mp}$, dens, $2, .1627^{*} .062428 / 1728 *$ Hel ium a $81^{\circ} \mathrm{F}$

$17 \mathrm{mp}$, dens, 3,.0939 * CsCl

$18 \mathrm{mp}$, dens, $4,1.177^{\star} .1627 / 1728$ * air a $81^{\circ} \mathrm{F}$

$19 \mathrm{rad} 1=2.250 / 2$ * outer radius, inner capsule

20 thk1 $=(2.250-1.978) / 2 *$ thickness of inner capsule

21 rad2 $=2.625 / 2 *$ outer radius, outer capsule

22 /com thk2 $=(2.625-2.353) / 2 *$ per dwg

23 thk2 $=(2.625-2.402) / 2 *$ per SARP p 3-11, thinner

$24 \mathrm{rad} 3=1.625$ * outer radius, type $\mathrm{W}$ overpack

25 thk3 $=0.125 *$ W overpack nominal thickness

$26 /$ com thk3 $=.11$ * thinnest overpack

$27 \mathrm{rad} 4=2.0 \quad * 3.5$ in pipe central support

28 thk4 $=0.226 *$ schd 40 central support thickness

29 rad5 $=4.25$ * radius of inner row of capsules

30 rad6 $=7.88$ * radius of outer row of capsules

$31 / \mathrm{com}$ rads $=4.0$ * radius of inner row of capsules * parametric variation

32 /con $\operatorname{rad} 6=7.63$ * radius of outer row of capsules * parametric variation

33 ang1 $=15$ * angular spacing in outer row

34 lcom $W=205 *$ watts per capsule

$35 \mathrm{~W}=195$ * watts per capsule

$36 \mathrm{NC}=2 *$ capsules per model

$37 \mathrm{pwr}=\mathrm{NC} * * 3.412 / 16 * \mathrm{Btu} / \mathrm{hr}-$ in of \#NC capsules per inch length

38 /com power per cu in will be calculated using power/total CsCl area

$39 \mathrm{pc}=0.50 * \%$ in $\mathrm{CsCl}$, increase slightly from SARP 0.48

40 pcp $=0.2 * \%$ in capsule steel \& overpack

41 /com try parametric variation:

42 /com $\mathrm{pc}=.37$ * based on shielding calc

43 /com pcp $=.24$

fn $=4.7 *$ fin factor, multiplies cylinder convection $\mathrm{film}$ constant 
54 /com ** if etemp changes, you must also change hf table for air

$55 / \mathrm{com}$ inst $=400 * \mathrm{~g}$-cal insolation per $\mathrm{sq} \mathrm{cm}$ over $12 \mathrm{hr}$

$56 / \mathrm{com}$ insl $=$ insl $* 2.54 * 2.54 / 252 / 12 *$ Btu/hr per sq in

57 insl $=100 * \mathrm{BTU} / \mathrm{hr}$ per sq. $\mathrm{ft}$ - Hanford value for flat surface (use 100)

58 insl $=0.5^{\star}$ insl/144 * BTU/hr per sq in for cylinder

59 /com enss $=0.5 *$ stainless steel emissivity

60 emss $=0.3$ * stainless steel emissivity

61 /con mat $1=$ stainles steel

$62 \mathrm{mp}, c, 1,460 * 2.39 \mathrm{e}-4$

$63 \mathrm{mp}$, emis, 1, emss 


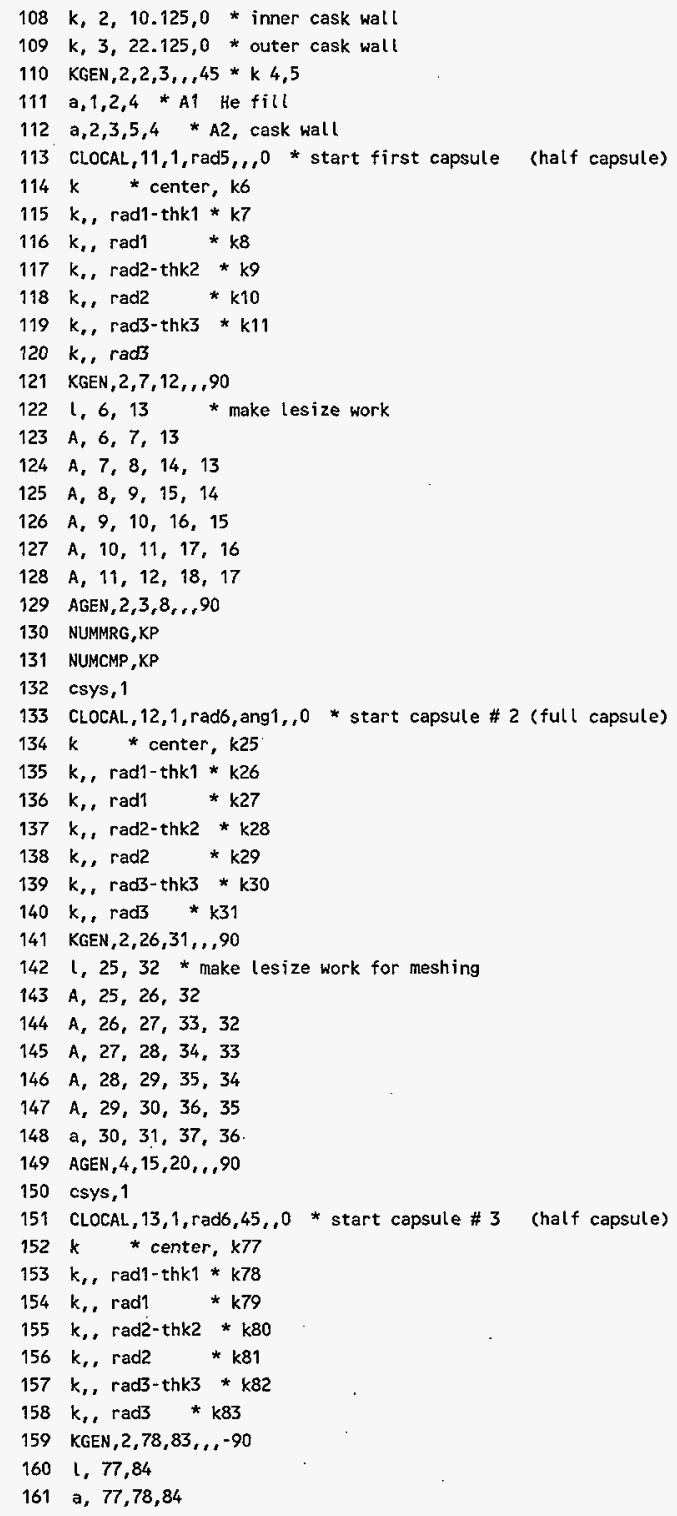




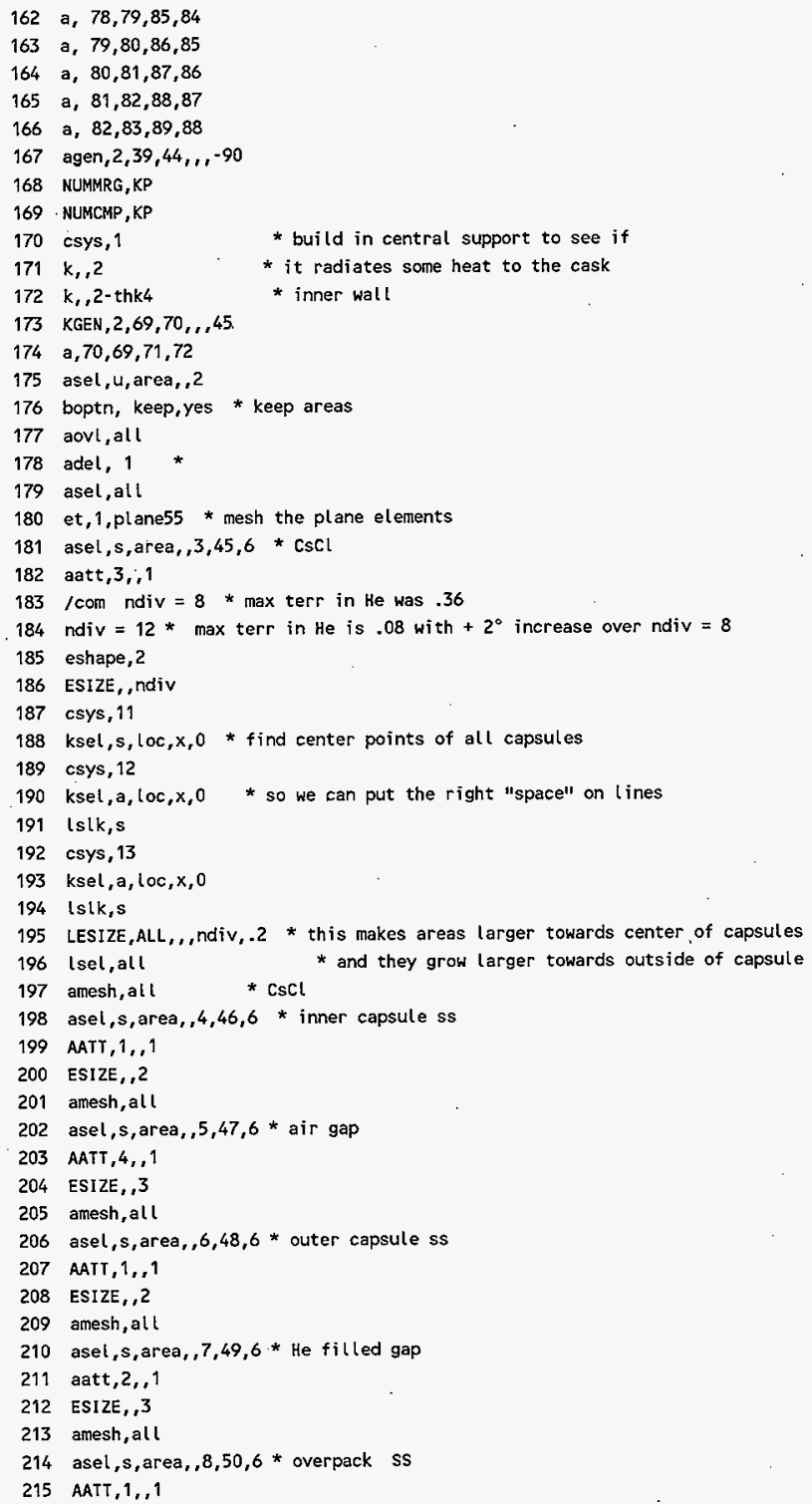




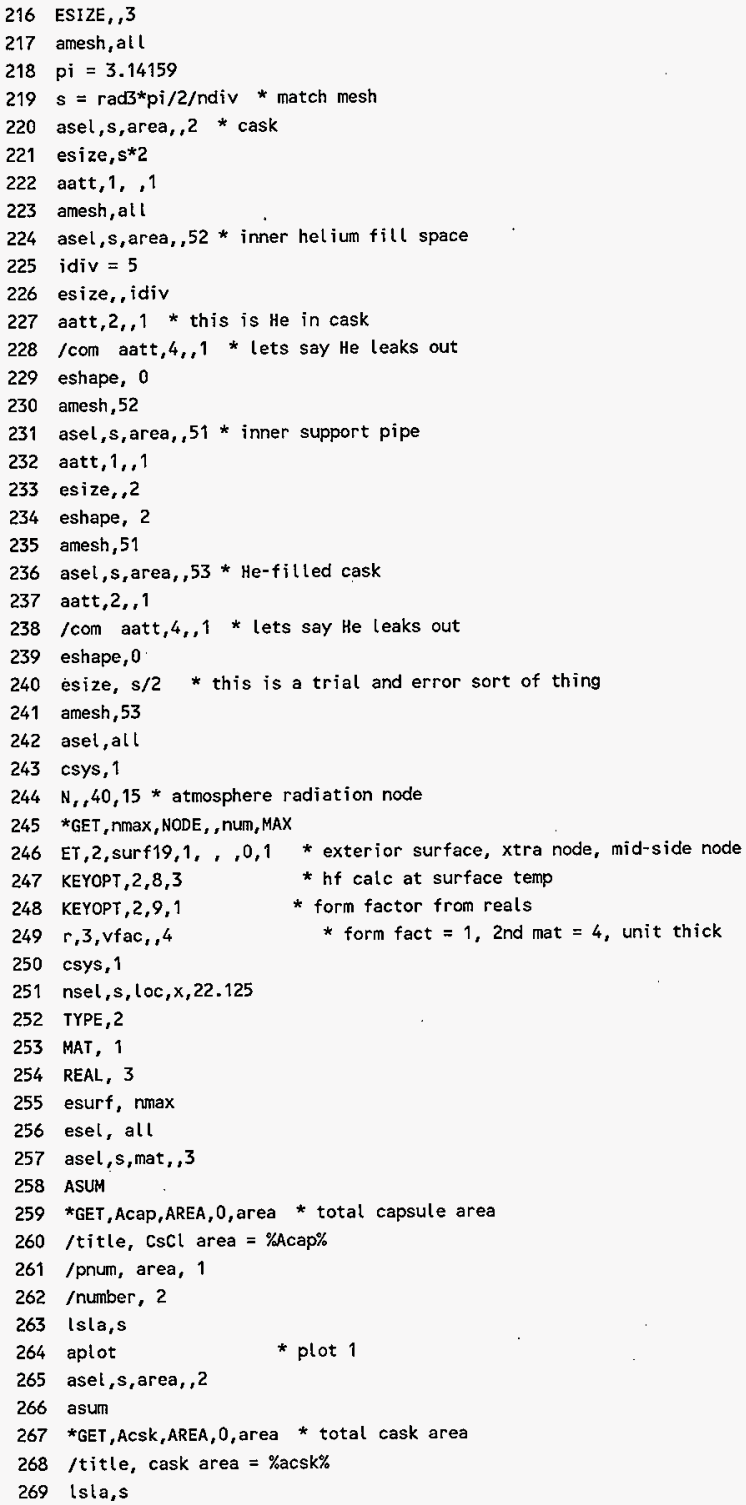




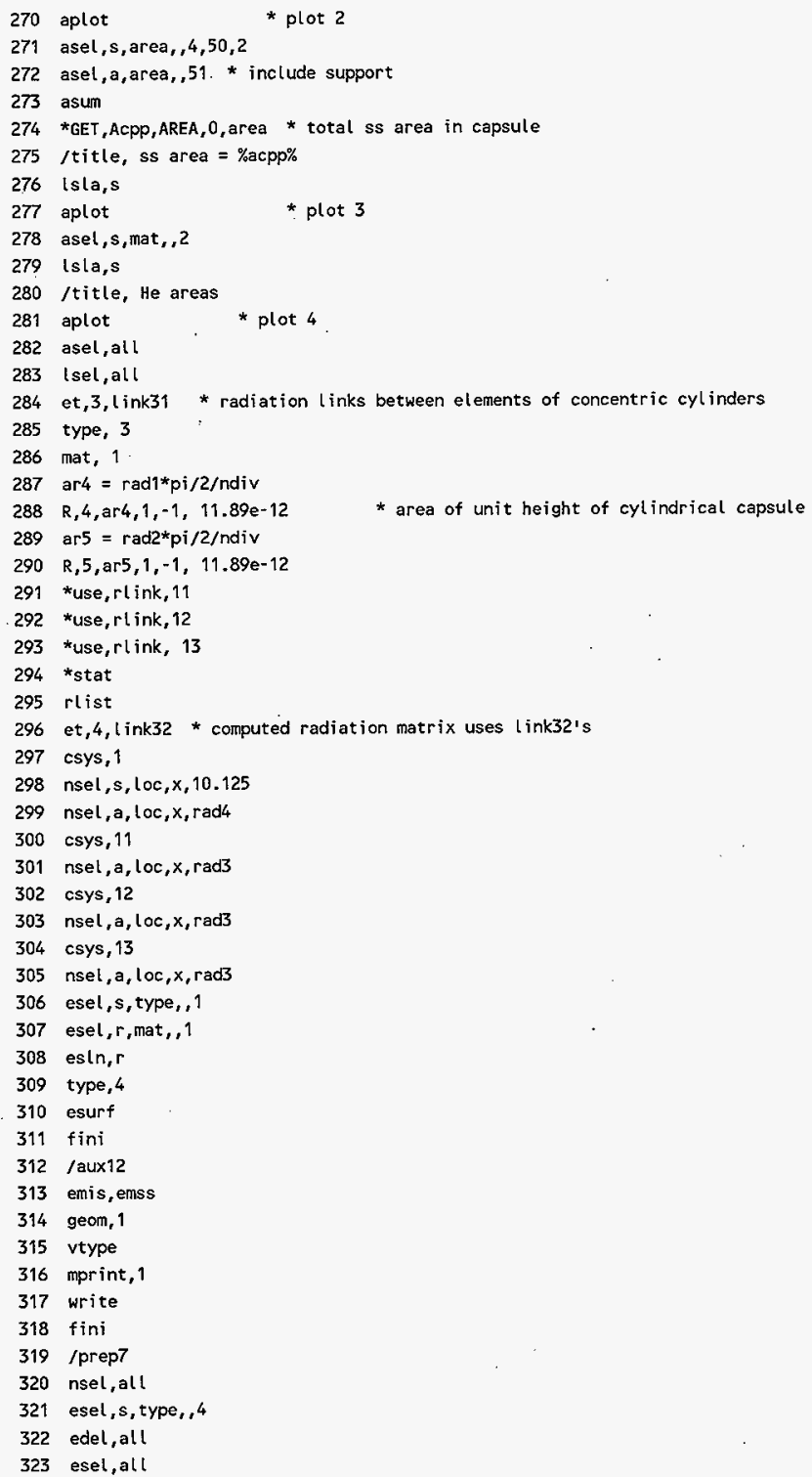




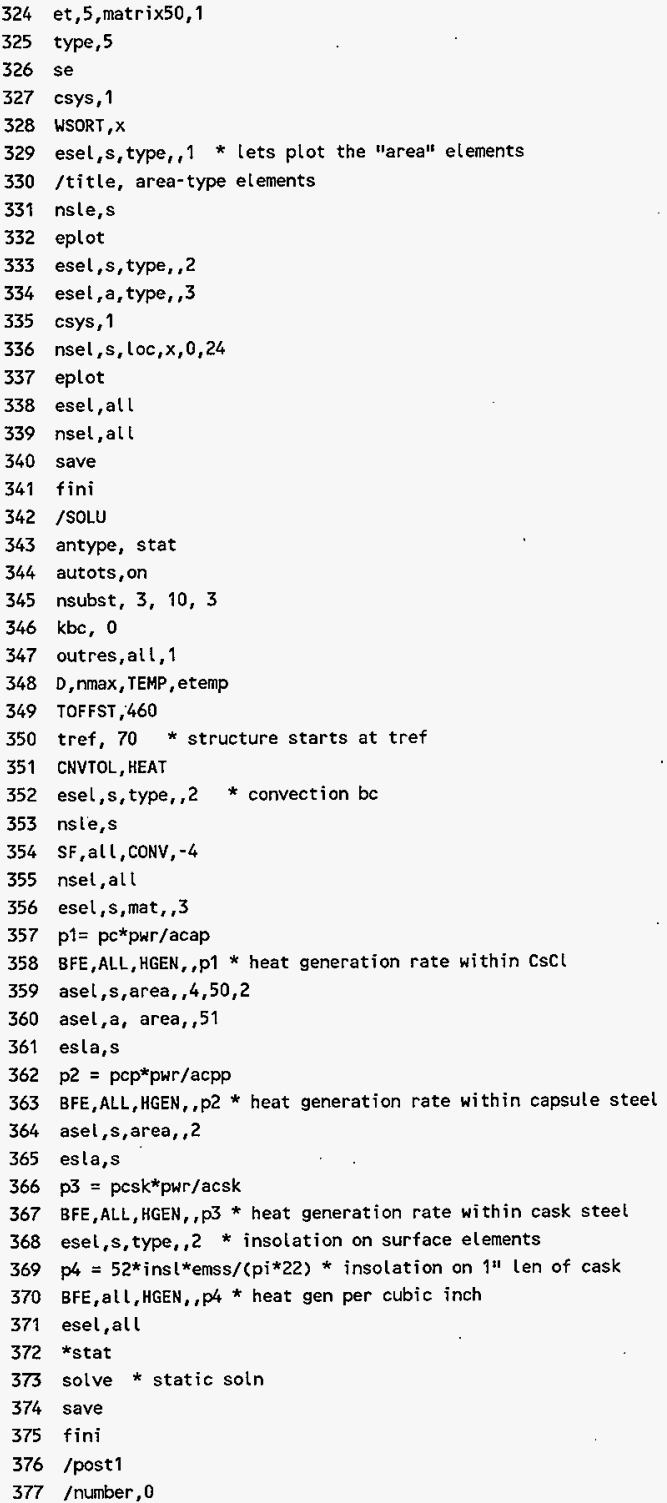




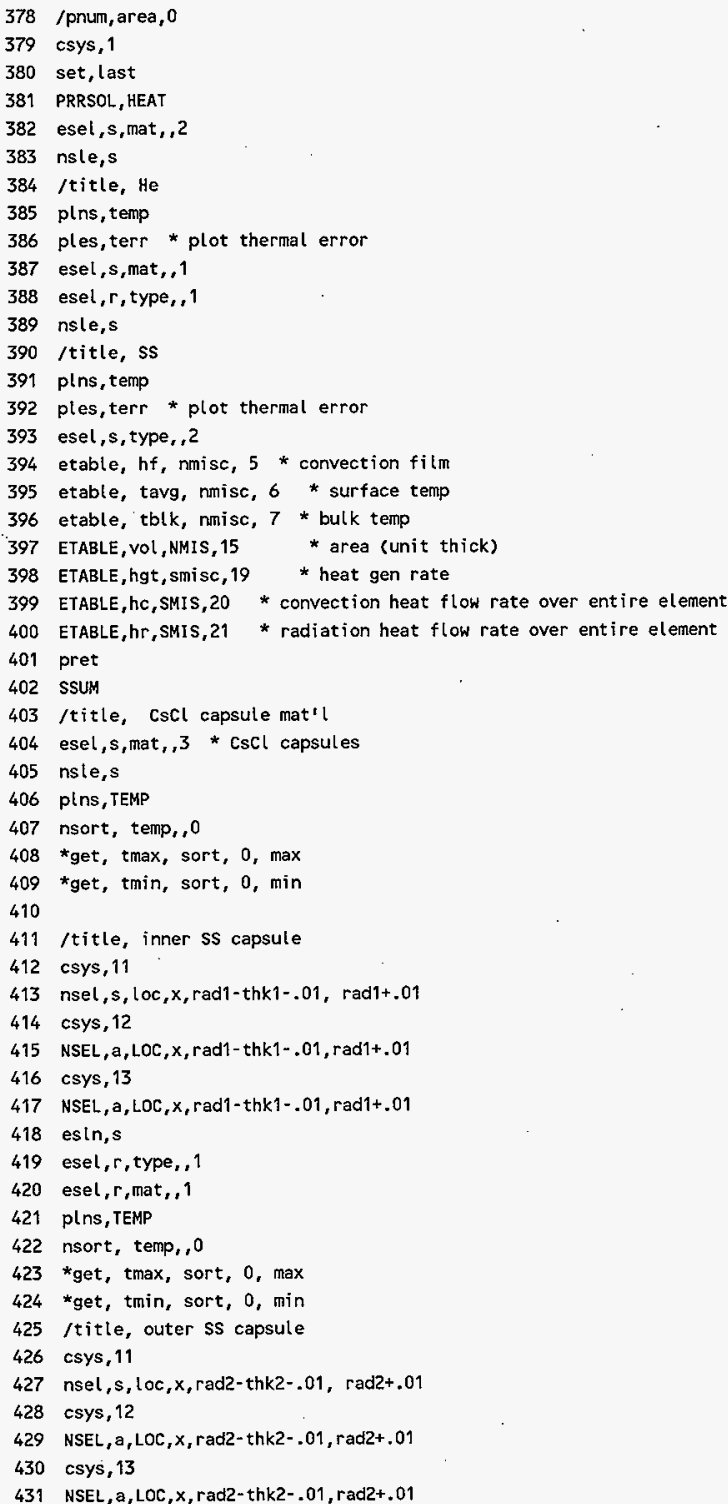




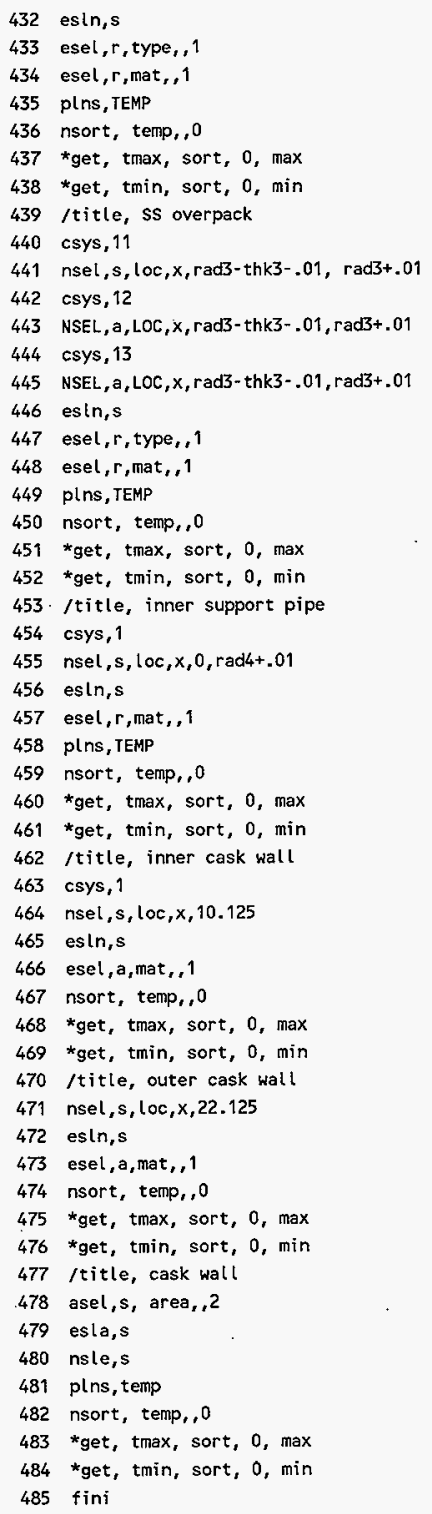




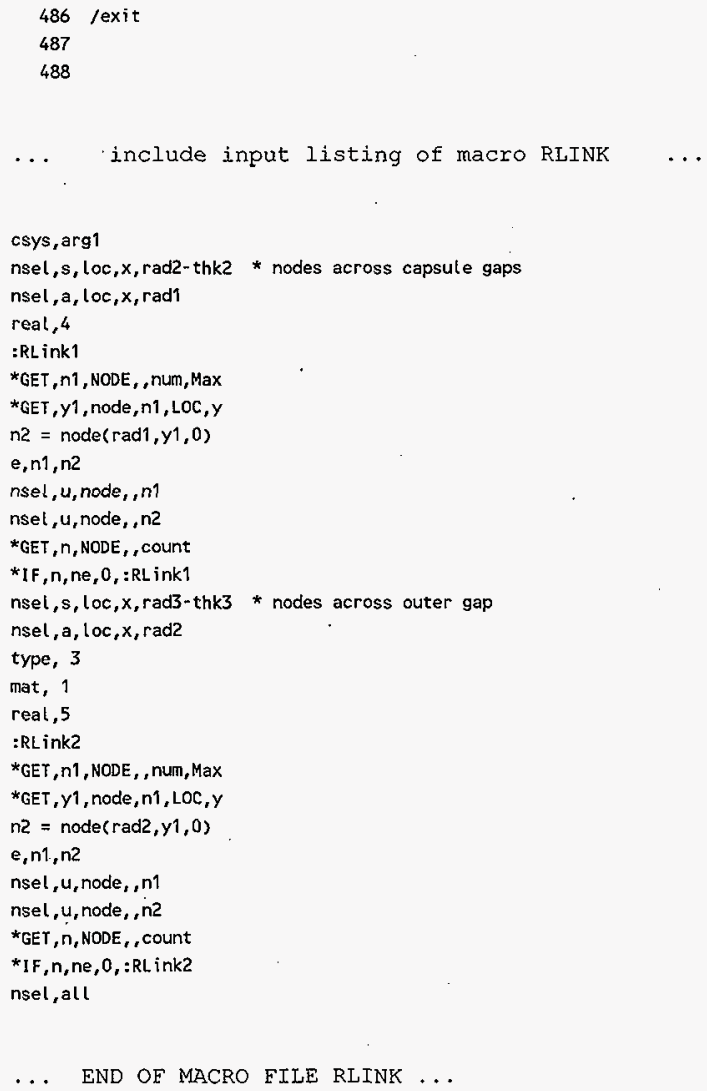




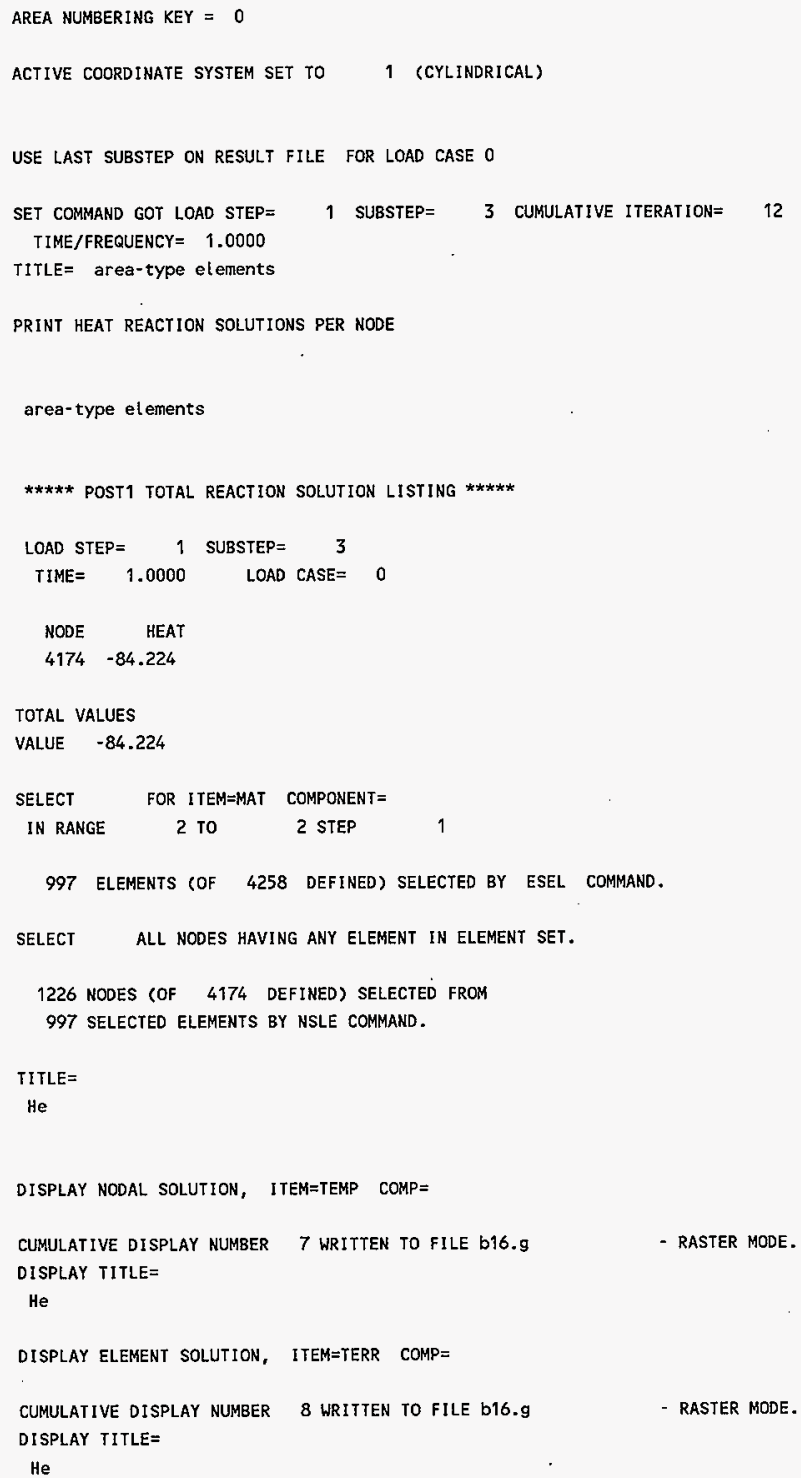




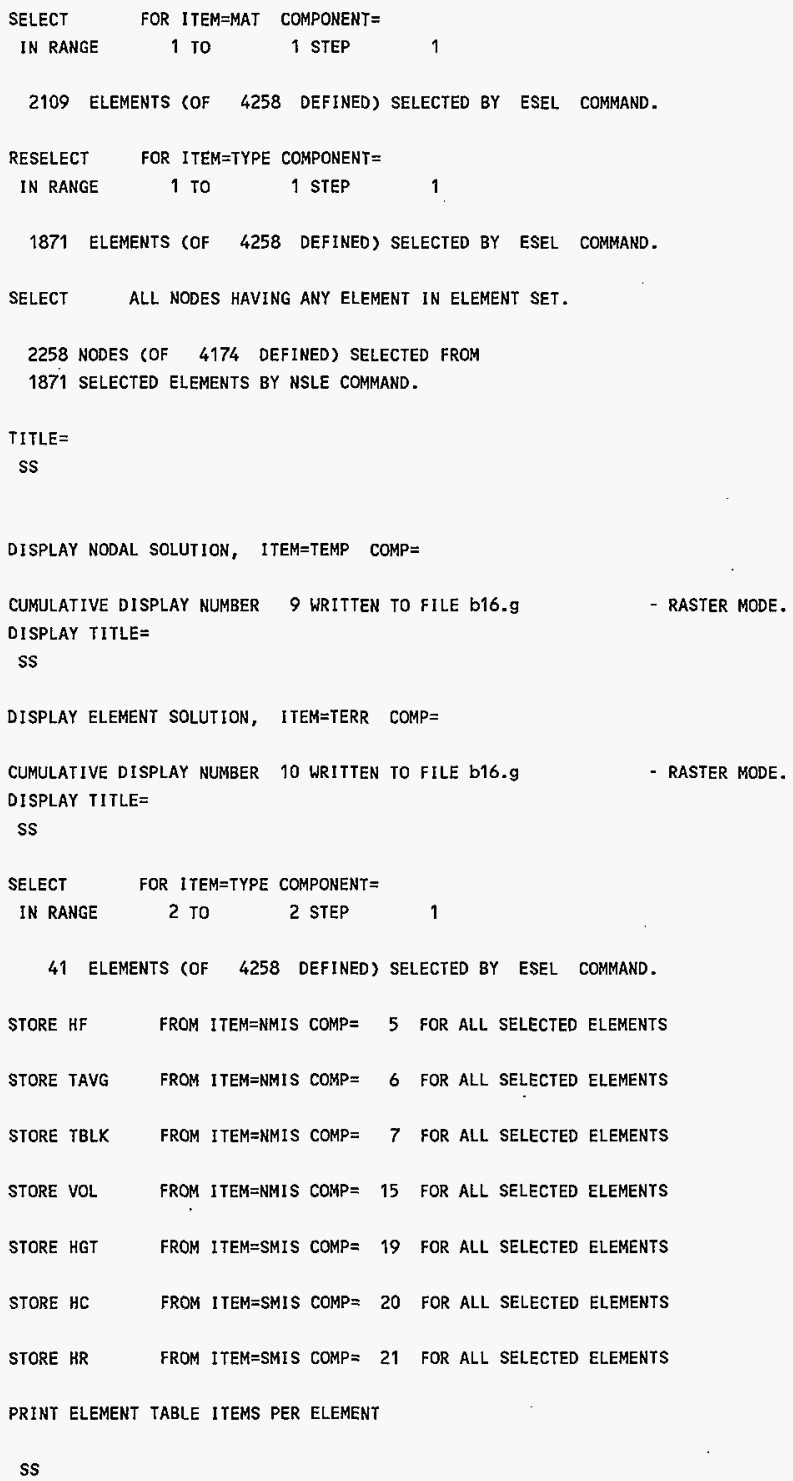




\begin{tabular}{|c|c|c|c|c|c|c|c|}
\hline STAT & CURRENT & CURRENT & CURRENT & CURRENT & CURRENT & CURRENT & CURRENT \\
\hline ELEM & HF & TAVG . & TBLK & VOL & HGT & $\mathrm{HC}$ & HR \\
\hline 4021 & $0.29284 E-01$ & 252.93 & 115.00 & 0.42382 & $0.33216 \mathrm{E}-01$ & 1.7119 & 0.33822 \\
\hline 4022 & $0.29284 \mathrm{E}-01$ & 252.93 & 115.00 & 0.42382 & $0.33216 E-01$ & 1.7119 & 0.33822 \\
\hline 4023 & $0.29284 E-01$ & 252.93 & 115.00 & 0.42382 & $0.33216 \mathrm{E}-01$ & 1.7119 & 0.33823 \\
\hline 4024 & $0.29285 E-01$ & 252.94 & 115.00 & 0.42382 & $0.33216 \mathrm{E}-01$ & 1.7120 & 0.33824 \\
\hline 4025 & $0.29285 E-01$ & 252.94 & 115.00 & 0.42382 & $0.33216 \mathrm{E}-01$ & 1.7121 & 0.33826 \\
\hline 4026 & $0.29285 E-01$ & 252.95 & 115.00 & 0.42382 & $0.33216 E-01$ & 1.7122 & 0.33828 \\
\hline 4027 & $0.29286 \mathrm{E}-01$ & 252.96 & 115.00 & 0.42382 & $0.33216 \mathrm{E}-01$ & 1.7123 & 0.33831 \\
\hline 4028 & $0.29287 E-01$ & 252.96 & 115.00 & 0.42382 & $0.33216 E-01$ & 1.7124 & 0.33833 \\
\hline 4029 & $0.29287 E-01$ & 252.97 & 115.00 & 0.42382 & $0.33216 \mathrm{E}-01$ & 1.7126 & 0.33837 \\
\hline 4030 & $0.29288 \mathrm{E}-01$ & 252.98 & 115.00 & 0.42382 & $0.33216 E-01$ & 1.7128 & 0.33840 \\
\hline 4031 & $0.29289 E-01$ & 253.00 & 115.00 & 0.42382 & $0.33216 \mathrm{E}-01$ & 1.7130 & 0.33844 \\
\hline 4032 & $0.29290 \mathrm{E}-01$ & 253.01 & 115.00 & 0.42382 & $0.33216 E-01$ & 1.7132 & 0.33848 \\
\hline 4033 & $0.29291 E-01$ & 253.02 & 115.00 & 0.42382 & $0.33216 \mathrm{E}-01$ & 1.7134 & 0.33852 \\
\hline 4034 & $0.29291 \mathrm{E}-01$ & 253.04 & 115.00 & 0.42382 & $0.33216 E-01$ & 1.7136 & 0.33857 \\
\hline 4035 & $0.29292 E-01$ & 253.05 & 115.00 & 0.42382 & $0.33216 E-01$ & 1.7139 & 0.33861 \\
\hline 4036 & $0.29294 E-01$ & 253.06 & 115.00 & 0.42382 & $0.33216 E-01$ & 1.7141 & 0.33866 \\
\hline 4037 & $0.29295 \mathrm{E}-01$ & 253.08 & 115.00 & 0.42382 & $0.33216 E-01$ & 1.7144 & 0.33879 \\
\hline 4038 & $0.29296 E-01$ & 253.10 & 115.00 & 0.42382 & $0.33216 E-01$ & 1.7146 & 0.33876 \\
\hline 4039 & $0.29297 \mathrm{E}-01$ & 253.11 & 115.00 & 0.42382 & $0.33216 \mathrm{E}-01$ & 1.7149 & 0.33882 \\
\hline 4040 & $0.29298 \mathrm{E}-01$ & 253.13 & 115.00 & 0.42382 & $0.33216 \mathrm{E}-01$ & 1.7151 & 0.33887 \\
\hline 4041 & $0.29299 E-01$ & 253.14 & 115.00 & 0.42382 & $0.33216 \mathrm{E}-01$ & 1.7154 & 0.33892 \\
\hline 4042 & 0.29300 E-01 & 253.16 & 115.00 & 0.42382 & $0.33216 E-01$ & 1.7156 & 0.33897 \\
\hline 4043 & $0.29301 E-01$ & 253.17 & 115.00 & 0.42382 & $0.33216 \mathrm{E}-01$ & 1.7159 & 0.33902 \\
\hline 4044 & $0.29302 E-01$ & 253.19 & 115.00 & 0.42382 & $0.33216 \mathrm{E}-01$ & 1.7162 & 0.33907 \\
\hline 4045 & $0.29303 E-01$ & 253.20 & 115.00 & 0.42382 & $0.33216 \mathrm{E}-01$ & 1.7164 & 0.33912 \\
\hline 4046 & $0.29304 \mathrm{E}-01$ & 253.22 & 115.00 & 0.42382 & $0.33216 E-01$ & 1.7166 & 0.33917 \\
\hline 4047 & $0.29305 E-01$ & 253.23 & 115.00 & 0.42382 & $0.33216 \mathrm{E}-01$ & 1.7169 & 0.33922 \\
\hline 4048 & $0.29306 \mathrm{E}-01$ & 253.25 & 115.00 & 0.42382 & $0.33216 \mathrm{E}-01$ & 1.7171 & 0.33926 \\
\hline 4049 & $0.29307 E-01$ & 253.26 & 115.00 & 0.42382 & $0.33216 \mathrm{E}-01$ & 1.7173 & 0.33930 \\
\hline 4050 & $0.29308 \mathrm{E}-01$ & 253.27 & 115.00 & 0.42382 & $0.33216 \mathrm{E}-01$ & 1.7175 & 0.33934 \\
\hline 4051 & $0.29309 E-01$ & 253.28 & 115.00 & 0.42382 & $0.33216 \mathrm{E}-01$ & 1.7177 & 0.33938 \\
\hline 4052 & $0.29309 E-01$ & 253.29 & 115.00 & 0.42382 & $0.33216 \mathrm{E}-01$ & 1.7179 & 0.33941 \\
\hline 4053 & $0.29310 E-01$ & 253.30 & 115.00 & 0.42382 & $0.33216 E-01$ & 1.7180 & 0.33944 \\
\hline 4054 & $0.29311 E-01$ & 253.31 & 115.00 & 0.42382 & $0.33216 \mathrm{E}-01$ & 1.7182 & 0.33947 \\
\hline 4055 & $0.29311 E-01$ & 253.32 & 115.00 & 0.42382 & $0.33216 E-01$ & 1.7183 & 0.33950 \\
\hline 4056 & $0.29312 \mathrm{E}-01$ & 253.32 & 115.00 & 0.42382 & $0.33216 \mathrm{E}-01$ & 1.7184 & 0.33952 \\
\hline 4057 & $0.29312 E-01$ & 253.33 & 115.00 & 0.42382 & $0.33216 \mathrm{E}-01$ & 1.7185 & 0.33954 \\
\hline 4058 & $0.29312 \mathrm{E}-01$ & 253.33 & 115.00 & 0.42382 & $0.33216 E-01$ & 1.7185 & 0.33955 \\
\hline 4059 & $0.29313 E-01$ & 253.34 & 115.00 & 0.42382 & $0.33216 E-01$ & 1.7186 & 0.33956 \\
\hline 4060 & $0.29313 E-01$ & 253.34 & 115.00 & 0.42382 & $0.33216 \mathrm{E}-01$ & 1.7186 & 0.33957 \\
\hline 4061 & $0.29313 E-01$ & 253.34 & 115.00 & 0.42382 & $0.33216 \mathrm{E}-01$ & 1.7187 & 0.33957 \\
\hline
\end{tabular}

\section{***** POST1 ELEMENT TABLE LISTING *****}

$\begin{array}{llllllll}\text { STAT } & \text { CURRENT } & \text { CURRENT } & \text { CURRENT } & \text { CURRENT } & \text { CURRENT } & \text { CURRENT } & \text { CURRENT } \\ \text { ELEM } & \text { HF } & \text { TAVG } & \text { TBLK } & \text { VOL } & \text { HGT } & \text { HC } & \text { HR }\end{array}$


HNF-SD-TP-SEP-065 Rev. 0

$\begin{array}{lcrrrrrr}\text { MINIMUM } & \text { VALUES } & & & & & & \\ \text { ELEM } & 4021 & 4021 & 4021 & 4021 & 4021 & 4021 & 4021 \\ \text { VALUE } & 0.29284 E-01 & 252.93 & 115.00 & 0.42382 & 0.33216 \mathrm{E}-01 & 1.7119 & 0.33822 \\ & & & & & & & \\ \text { MAXIMUM } & \text { VALUES } & & & & & & \\ \text { ELEM } & 4061 & 4061 & 4021 & 4061 & 4061 & 4061 & 4061 \\ \text { VALUE } & 0.29313 E-01 & 253.34 & 115.00 & 0.42382 & 0.33216 \mathrm{E}-01 & 1.7187 & 0.33957\end{array}$

SUM ALL THE ACTIVE ENTRIES IN THE ELEMENT TABLE

\begin{tabular}{|c|c|}
\hline TABLE & TO \\
\hline HF & 1.20125 \\
\hline TAVG & 10378.7 \\
\hline TBLK & 4715.00 \\
\hline VOL & 17.3767 \\
\hline HGT & 1.36184 \\
\hline $\mathrm{HC}$ & 70.3284 \\
\hline HR & 13.8952 \\
\hline
\end{tabular}

TITLE=

Cscl capsule mat'l

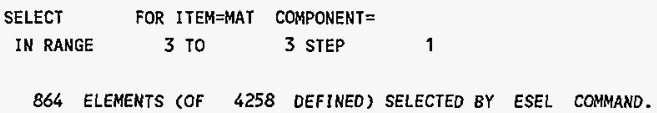

SELECT ALL NODES HAVING ANY ELEMENT IN ELEMENT SET.

939 NODES (OF 4174 DEFINED) SELECTED FROM

864 SELECJED ELEMENTS BY NSLE COMMAND.

DISPLAY NODAL SOLUIION, ITEM=TEMP COMP=

CUMULATIVE DISPLAY NUMBER 11 WRITTEN TO FILE b16.g - RASTER MODE. DISPLAY TITLE=

Cscl capsule mat'l

SORT ON ITEM=TEMP COMPONENT $=\quad$ ORDER $=0 \quad$ KABS $=0 \quad$ NMAX $=4174$

SORT COMPLETEO FOR 939 VALUES.

*GET tmax FROM SORT ITEM=MAX VALUE $=863.833883$

*GET tmin FROM SORT ITEM=MIN VALUE $=667.540466$

TITLE=

inner ss capsule

ACTIVE COORDINATE SYSTEM SET TO 11 (CYLINDRICAL)

SELECT FOR ITEM=LOC COMPONENT $=X$ BETWEEN 0.97900 AND 1.1350 


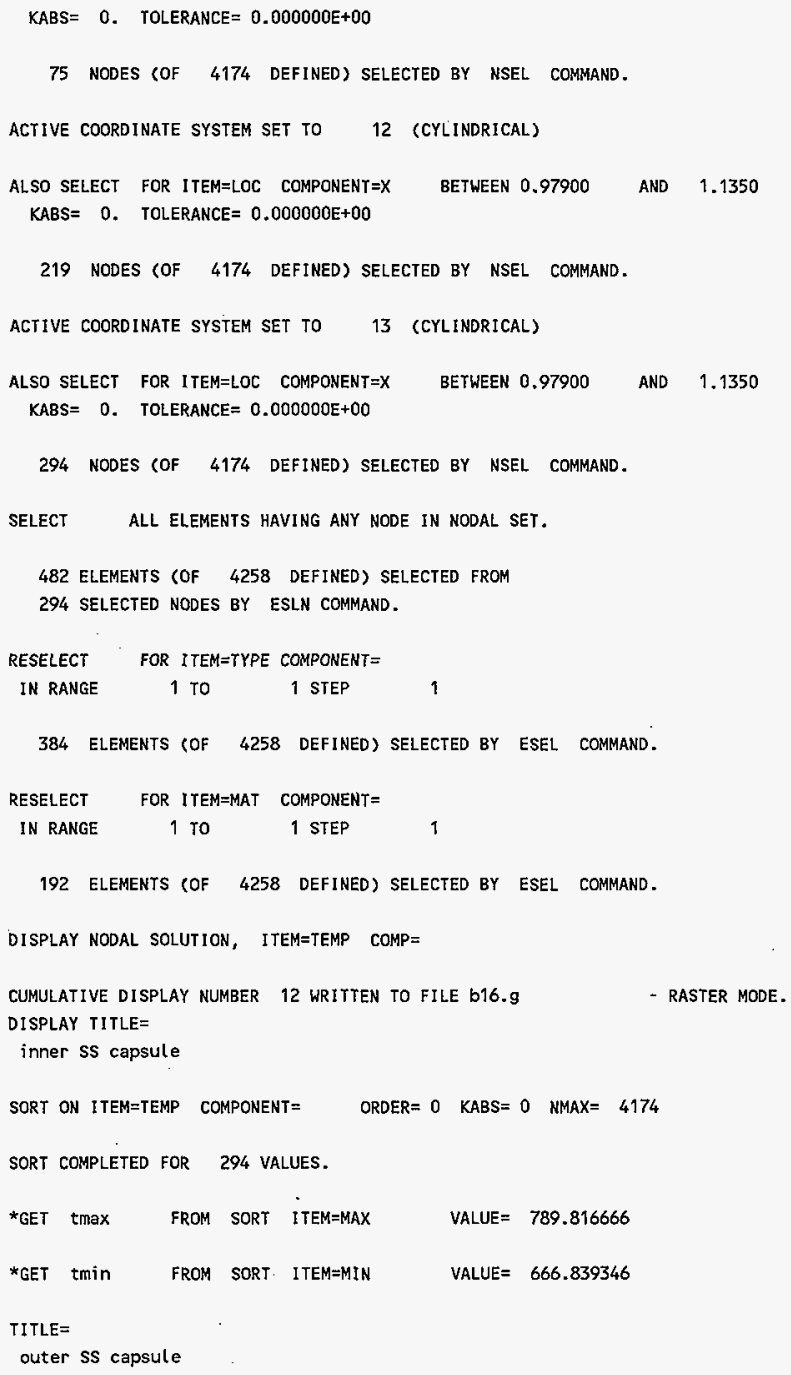




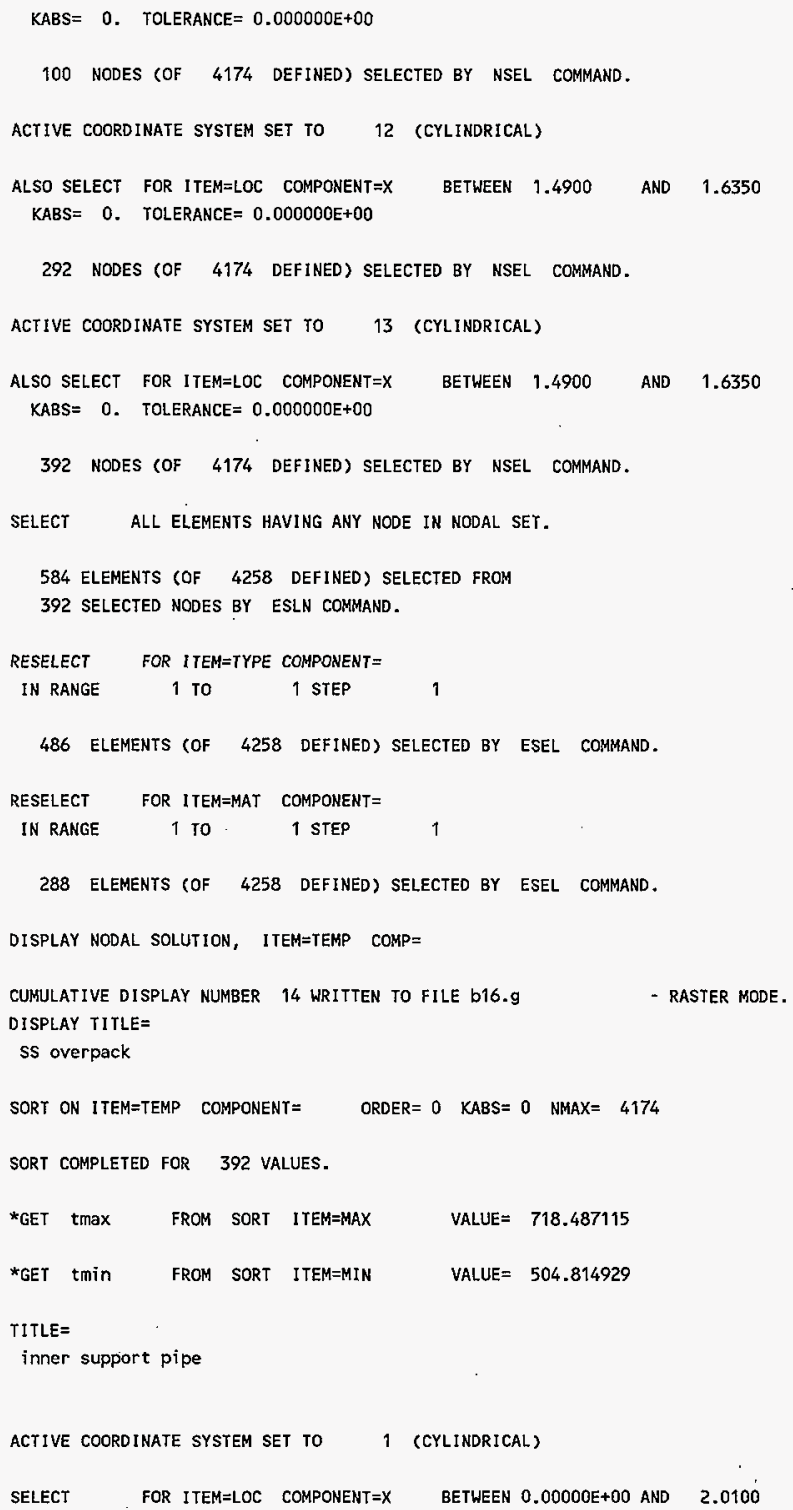




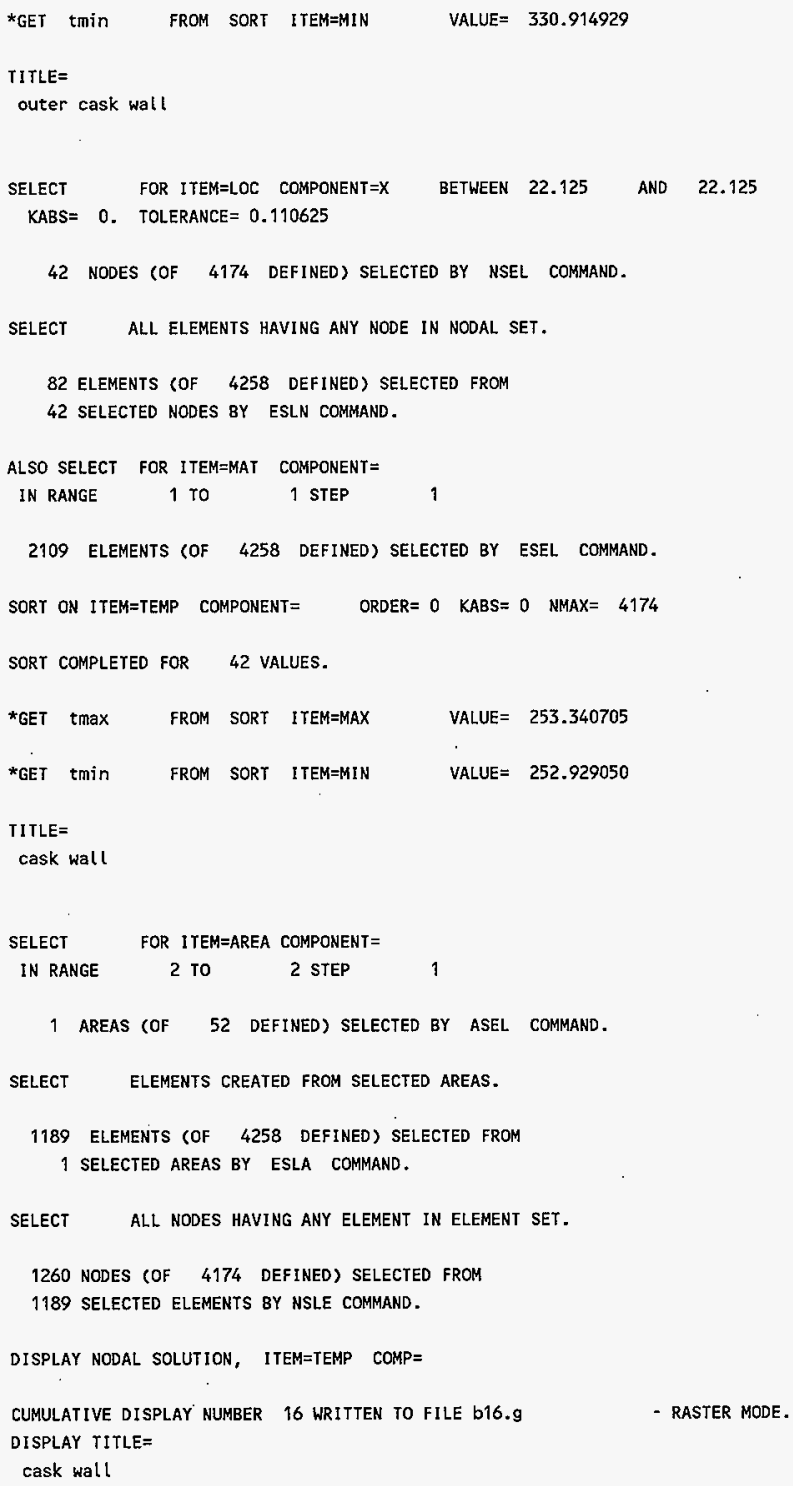


SORT ON ITEM $=$ TEMP COMPONENT $=\quad$ OROER $=0 \quad \mathrm{KABS}=0 \quad$ NMAX $=4174$

SORT COMPLETED FOR 1260 VALUES.

*GET tInax FROM SORT ITEM=MAX VALUE $=337.804347$

*GET tmin FROM SORT ITEM=MIN VALUE $=252.929050$

EXIT THE ANSYS POST1 DATABASE PROCESSOR

***** ROUTINE COMPLETED ***** CP $=\quad 510.710$

PURGE ALL SOLUTION AND POST DATA

SAVE ALL MODEL DATA

ALL CURRENT ANSYS DATA WRITTEN TO FILE NAME $=\mathrm{b} 16 \mathrm{a} . \mathrm{db}$ FOR POSSIBLE RESUME FROM THIS POINT

NUMBER OF WARNING MESSAGES ENCOUNTERED= 4 NUMBER OF ERROR MESSAGES ENCOUNTERED $=\quad 0$

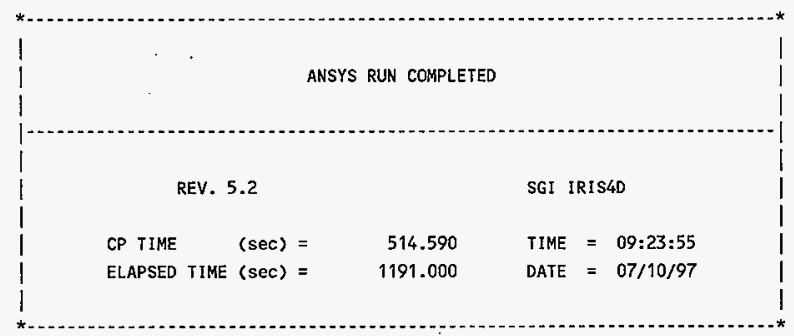

487.2u 27.4s 19:50 43\% 0+0k 903+17801io $286 \mathrm{pf}+0 \mathrm{w}$

Ran ANSY 5.2 on workstation: sgi3 on: Thu Jul 10 09:23:55 PDT 1997 ANSYS 5.2 has been verified by ICF KH Class 3 Error Reports are in the directory: /apps/ansys/class3_errors. 


\subsubsection{Peer Review Checklist}

\section{CHECKLIST FOR PEER REYIEW}

Document Reviewed: Thermal Analysis for the BUSS Cask SEP, HNF-SD-TP-SEP-065

Scope of Review: Entire themal anaiysis - Chapter B 8

Yes Ne NA

[ ] [ ] [X] Previous reviews complete and cover analysis, up to scope of this review, with no gaps.

[A [ ] [ ] Problem completely defined.

[ ] [ ] [X] Accident scenarios developed in a clear and logical manner.

D4 [ ] [ ] Necessary assumptions explicitly stated and supported.

$\rightarrow$ [ I [ ] Comiputer codes and data files documented.

Du [ ] [ ] Data used in calculations explicitly stated in document.

[4 [ ] [ ] Data checked for consistency with original source information as applicable.

4. [ ] [ ] Mathematical derivations checked including dimensional consistency of results.

[4 [ ] [ ] Kodels appropriate and used within range of validity or use outside range of established validity justified.

1 [ I [ Hand calculations checked for errors. Spreadsheet results should be treated exactly the same as hand calculations.

4 [ ] [ ] Software input correct and consistent with document reviewed.

[4 [ ] [ ] Software output consistent with input and with results reported in document reviewed.

[4] [ ] [ ] Limits/criteria/guidelines applied to analysis results are appropriate and referenced. Limits/criteria/guidelines checked against references.

[4] [ ] [ ] Safety margins consistent with good engineering practices.

[4 [ ] [ ] Conclusions consistent with analytical results and applicable limits.

[4] [ 1 [ ] Results and conclusions address all points required in the problem statement.

[ ] [ ] 4 Fornat consistent with appropriate MRC Regulatory Guide or other standards

[ ] be Review calculations, comments, and/or notes are attached.

[A [ I [ ] Document approved.

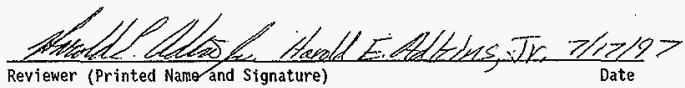


This page intentionally left blank. 


\subsection{PRESSURE AND GAS GENERATION}

As no liquid is shipped in the package, so the only source of pressure will be due to the increase in temperature. Even if the temperature were to rise to a uniform $800^{\circ} \mathrm{C}$ (the maximum fire temperature), the pressure would be:

$$
\frac{P_{2}}{P_{1}}=\frac{T_{2}}{T_{1}}
$$

assume $T_{1}=20^{\circ} \mathrm{C}$ and $P_{1}=1 \mathrm{~atm}$

$$
\text { then } \begin{aligned}
P_{2} & =\frac{273+800}{273+20}=3.66 \mathrm{~atm} \text { absolute } \\
P_{2} & =(3.66-1) 14.7=39 \mathrm{psig}
\end{aligned}
$$

As demonstrated in the BUSS Cask SARP (SNL 1994), this is below the maximum allowed pressure of 50 psig and no further analyses is required.

\subsection{REFERENCE}

SNL, 1994, Beneficial Uses Shipping System (BUSS) Cask Safety Analysis Report for Packaging (SARP), Volumes I and II, SAND83-0698 (TCC-0430), Rev. 5, Sandia National Laboratories, Albuquerque, New Mexico. 
HNF-SD-TP-SEP-065 Rev. 0

This page intentionally left blank.

B9-2 


\subsection{TIEDOWN EVALUATION}

The package will be transported in its normal highway configuration as shown in the BUSS Cask SARP (SNL 1994). As a part of this, the cask as secured to a skid which is permanently attached to the trailer. The skid attachment is inspected annually as a part of routine maintenance.

\subsection{REFERENCE}

SNL, 1994, Beneficial Uses Shipping System (BUSS) Cask Safety Analysis Report for Packaging (SARP), Volumes I and II, SAND83-0698 (TCC-0430), Rev. 5, Sandia National Laboratories, Albuquerque, New Mexico. 


\begin{tabular}{|c|c|c|c|c|c|}
\hline \multicolumn{6}{|c|}{ DISTRIBUTION SHEET } \\
\hline To & \multirow{2}{*}{\multicolumn{3}{|c|}{$\begin{array}{l}\text { From } \\
\text { Packaging Engineering }\end{array}$}} & \multicolumn{2}{|c|}{ Page 1 of 1} \\
\hline Distribution & & & & \multicolumn{2}{|c|}{ Date $09 / 10 / 97$} \\
\hline \multicolumn{4}{|c|}{ Project Title/Work Order } & \multicolumn{2}{|c|}{ EDT No. 621893} \\
\hline \multicolumn{6}{|c|}{$\begin{array}{l}\text { Safety Evaluation for Packaging (Onsite) for Cesium Chloride } \\
\text { Capsules with Type W Overpacks (HNF-SD-TP-SEP-065) }\end{array}$} \\
\hline Name & MSIN & $\begin{array}{c}\text { Text } \\
\text { With All } \\
\text { Attach. }\end{array}$ & Text Only & $\begin{array}{l}\text { Attach./ } \\
\text { Appendix } \\
\text { Only }\end{array}$ & $\begin{array}{l}\text { EDT/ECN } \\
\text { Only }\end{array}$ \\
\hline $\begin{array}{l}\text { J. G. Field } \\
\text { C. R. Hoover } \\
\text { D. W. McNaliy } \\
\text { M. M. Pereira (2 copies) } \\
\text { HNF-SD-TP-SEP-0 } 65 \text { File } \\
\text { Central Files ( } 1 \text { copy + original) }\end{array}$ & $\begin{array}{l}H 1-15 \\
H 1-15 \\
G 1-15 \\
\text { S6-51 } \\
H 1-15 \\
\text { A3-88 }\end{array}$ & $\begin{array}{l}x \\
X \\
X \\
X \\
X \\
X \\
\end{array}$ & & & \\
\hline
\end{tabular}

